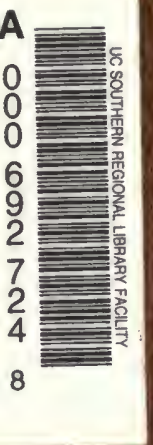


$B^{B P A R} R$

$y$ of

A' 1 . ILA

NN UIEGO 


\section{THE UNIVERSITY LIBRARY}

\section{UNIVERSITY OF CALIFORNIA, SAN DIEGO}

LA JOLLA; CALIFORNIA 
Digitized by the Internet Archive in 2007 with funding from Microsoft Corporation 
HOME UNIVERSITY LIBRARY

OF MODERN KNOWLEDGE

PROBLEMS OF VILLAGE LIFE

BY

E. N. BENNETT, M.A.

LONDON

WILLIAMS \& NORGATE

HENRY HOLT \& CO., NEW YOR Canada: WM. BRIgGs, Toronto INDIA : R. \& T. WASHBOURNE, LTD. 


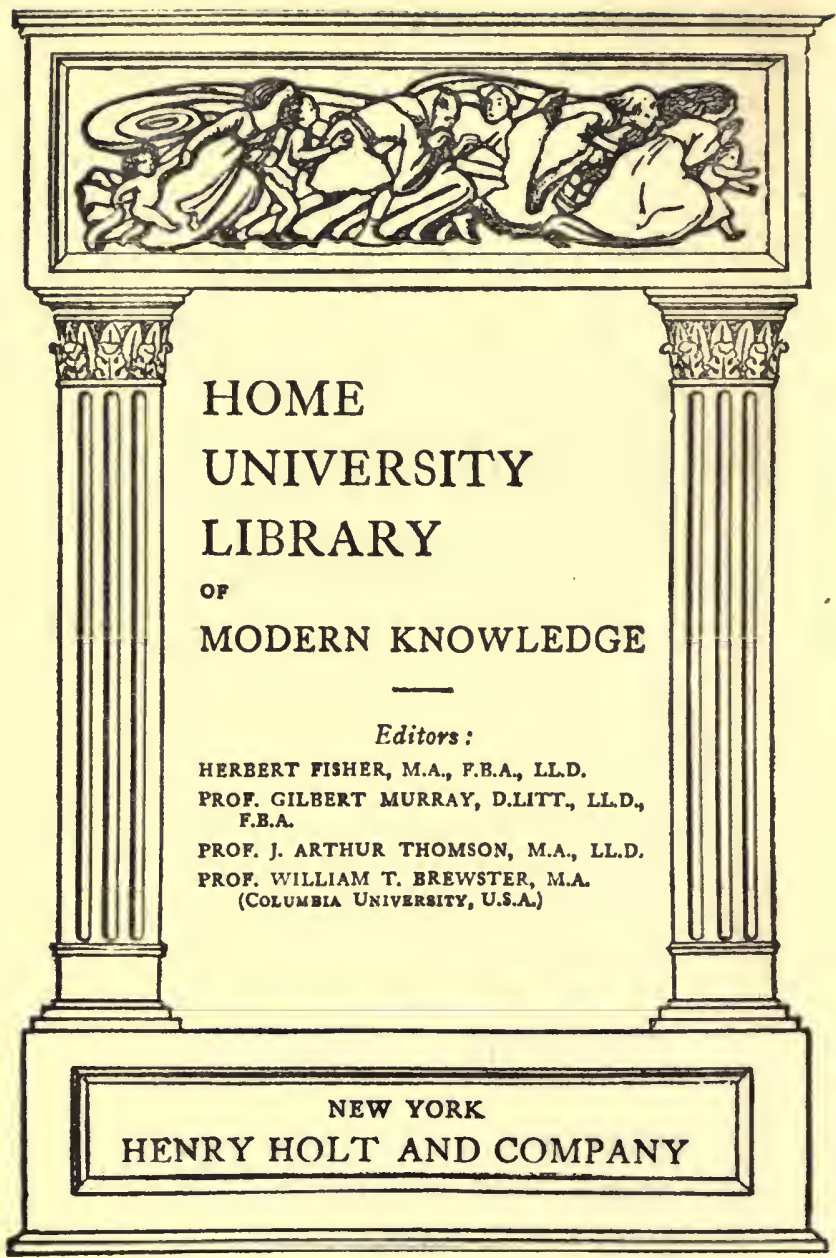



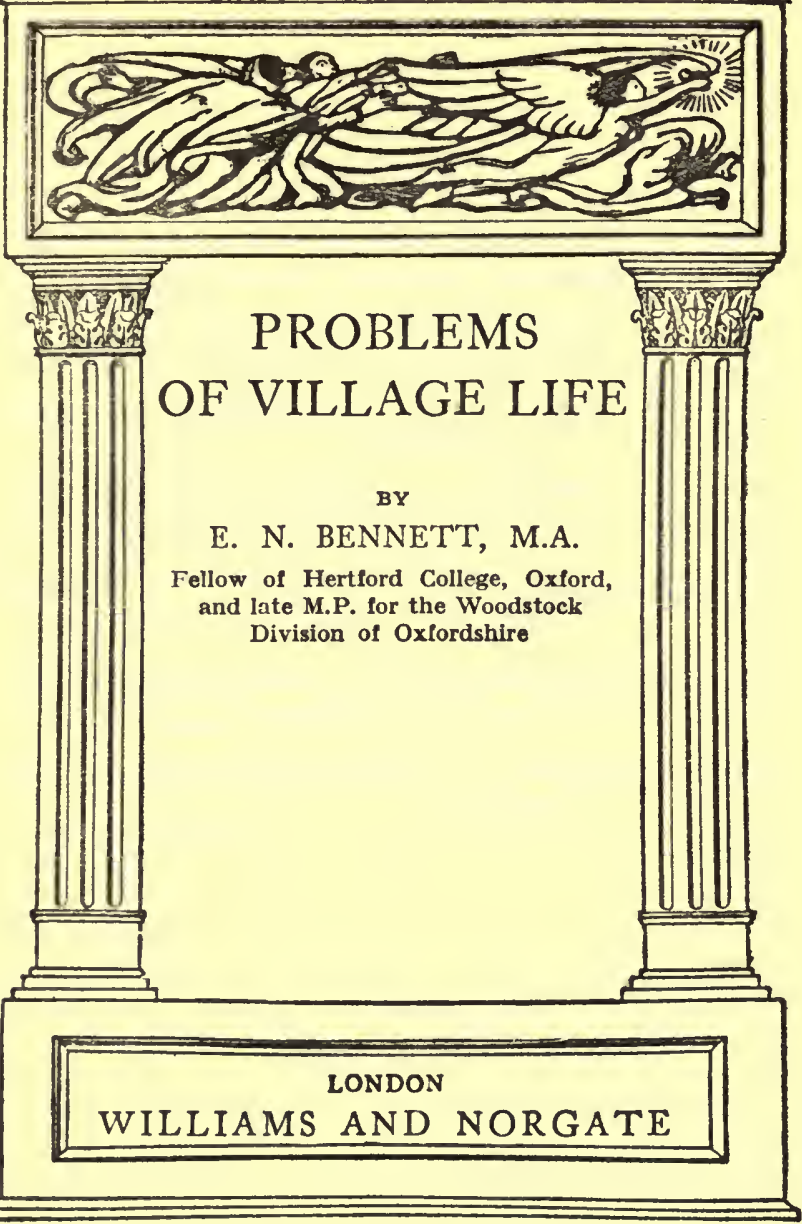
The following volumes of kindred interest have already been published in the Home University Library :-

Vol. 26.-AGRICUltURE. By Prof. W. Somervirte.

Vor. 36.-Climate AND WEATHER. By Prof. H. N. Dickson.

Vol. 59.-POLITICAL ECONOMY. By Prof. S. J. Chapman.

Vol. 72.-PLANT Life. By Prof. J. B. Farmer, F.R.S.

Vol. 24.-THE EVOLUTION OF INDUSTRY. By Prof. D. H. MacGregor.

Vol. 33.-History OF ENGLAND. By Prof. A. F. Pollard. 


\section{CONTENTS}

CHAPTER

Preface

I The Story of the Enguish Land • 13

II Rural England of To-day • • $\quad 37$

III The Rural Exodus . . . $\quad$ - 59

IV Rural Eddcation . • • • • 95

V Vintage Politics . • . . . 106

VI Religion of the Village • • . 120

VII Homes AND Wages . . • . 141

VIII Small Holdings • . . . . 163

IX Co-operation and CRedr . . 198

X Some Other Remedies • . • . 206

Biblography. • • • • . 251

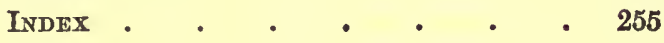





\section{PREFACE}

IN the midst of the great industrial developments which followed the close of the Napoleonic wars the claims of the rural population were to a large extent overlooked. So amazing was the realized and prospective wealth of a " nation of shopkeepers" who had made good their claim to control the trade routes of the world that the eyes of the nation were turned almost exclusively upon the towns and seaports. In the present century again, amid the ever-increasing volume of England's trade and her abounding riches, accompanied at the same time by a social unrest of unprecedented force, the attention of our country and those who guide its destiny is chiefly centred upon urban interests and urban demands. Trade rivals have menaced or destroyed some of our monopolies, and our earlier claim to be the workshop of the world must nowadays necessarily submit to modification ; but we have not yet as a nation learnt the true value of our fertile fields and the men who cultivate them. Agriculture, indeed, 
shares with Sociology the character of being perhaps the most backward of the applied sciences. In many other directions the splendid inventiveness of man has made giant strides-

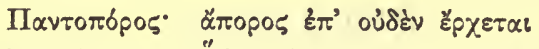

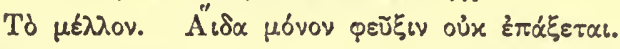

We have mastered the principles of aerial flight and wireless telegraphy; our submarines navigate the depths of the sea; we can analyze and weigh the planets. But many of the problems of poverty are still unsolved, and agriculture, the earliest and most universal of the sciences, makes but slow progress. It even appears probable that many parts of the globe's surface are cultivated with far less success now than in earlier centuries. In our own country no land drainage on scientific lines appeared until 1835; and the formation of artificial soils by mixture, discussed by Columella and even earlier writers, is still in its infancy as far as England is concerned.

The complaint, so often heard in country districts, that the agricultural population "does not count" is not without foundation. Of the eleven chapters in Mr. Masterman's admirable book The Condition of England, only one deals with the sociology of the countryside. "Nobody," said a farmer to 
Mr. Rider Haggard, "cares twopence how many quarters of wheat we produce." In a still greater degree does the existence of the poorer type of villager tend to be ignored. The valuable information contained in Rural England is derived almost entirely from squires, farmers and land agents: how seldom in these pages do we come across conversations with farm labourers. Mr. Wilson Fox's careful statistics of agricultural wages would have been even more reliable had they not been based so largely on returns made by employers. At "Fat Stock Dinners" and the like, the toast of "Agriculture" always has reference to the prosperity of landlords and farmers : and, in response, you will hear employers and landagents regretting the "good old days of agriculture," when wheat was 60/- a quarter and the labourers suffered cruelly from dear food and wretched wages. It is a significant fact that the only complete and scientific history of the English agricultural labourer has been written by a foreigner, Herr Hasbach. No apology, therefore, is needed by any writer who strives, in however humble a fashion, to focus the attention of his fellow-citizens on the problems of rural England.

Against one danger any author who deals 
with our rural life must be on his guard. It is by no means easy to discuss the social conditions of the countryside without being drawn, perhaps almost insensibly, into the vortex of party politics. All existing accounts, in fact, of rural life and economy have been in a greater or lesser degree coloured by the convictions and sentiments of the writer. This is self-evident, for example, in the writings of Cobbett, Young, and Joseph Arch. Those who love the country and its neglected people are bound to feel strongly, and, in face of our heavy arrears of national duty to the village, tend to grow impatient with further delays, excuses and compromises. Nevertheless, the writer of this little book will do his best to prevent any personal sympathies from minimising or obscuring the beneficent efforts of political opponents working for a common end. No Liberal can write with fuller knowledge, a more heartfelt sympathy for the poor village labourer, or a more genuine desire to improve British agriculture than $\mathbf{M r}$. Christopher Turnor, a Conservative landlord, or Mr. Jesse Collings, to whose clear and interesting volume on "Land Reform" we owe so much.

My grateful acknowledgments are due to Mr. C. R. Buxton, who generously placed at 
my disposal the manuscript of a book on country life compiled by him some years ago, but never published. I have not hesitated to insert here and there some considerable portions of this manuscript almost verbatim. I wish also to thank the Editors of the Contemporary Review and the Nation for their permission to reprint certain paragraphs from articles formerly contributed to these journals by myself.

These pages were already in the press when the Report of the Land Enquiry Committee, Vol. I., made its appearance; I was therefore, to my great regret, unable to avail myself of the invaluable information presented by the Committee.

E. N. B. 



\section{PROBLEMS OF VILLAGE LIFE}

\section{CHAPTER I}

THE STORY OF THE ENGLISH LAND

The conditions of rural life in England are to a large extent unique. Nowhere in Europe is so large a proportion of the population permanently divorced from the land, nowhere else is farming carried on by such loose and careless methods or is the land so much the "pleasure ground of the few" rather than the "treasure house of the many," nowhere else do you find a large class of men existing on similar lines to those of our agricultural labourers. The present system, with all its attendant problems, forms, perhaps, the clearest example of social and political evolution met with in history. So monotonous have been the annals of rural England, so powerful the small minority of its population, so helpless the large majority, 


\section{PROBLEMS OF VILLAGE LIFE}

that the story of the English land is revealed as little more than a register of obvious forces which have been directed from the Norman Conquest onwards to one definite end. The leading features of village life to-day, the hopelessness, the landlessness, are the direct outcome of the Feudal System, the Enclosure Acts, and the many Acts of regulation and repression which a small fraction of the nation have succeeded in placing upon the Statute Book of the realm.

The manorial system of the Norman period was based on the service of freemen and villeins rendered to the lord in person or to his bailiff. The land outside the lord's own demesne was farmed by these tenants, who, whether free or bondsmen, were liable for forty days of military service whenever summoned, and a variety of other dues in the shape of tallage, fines, or manual labour. The villein by blood, however, was " bound to the soil," unable to leave the land without his lord's permission, and exposed to a variety of harassing and humiliating exactions if he was unfortunate enough to serve a harsh master. In the Colloquy of Aelfric, the ploughman serf says : "I work hard, I go out at daybreak, driving the oxen to the field, and I yoke them to the plough. Be it never so 


\section{STORY OF THE ENGLISH LAND 15}

stark winter I dare not linger at home for awe of my lord. . . . I have a boy driving the oxen with a goad iron, who is hoarse with cold and shouting . . . mighty hard work it is, for I am not free." At the end of the twelfth century the Canons of Osney could procure a serf for $£ 4$ and a horse, or, in another case, 20 shillings.

From several causes, including the Church's disapproval of unqualified slavery, the bondsmen gradually improved their position, and by the middle of the fourteenth century an economic change had come to pass which radically altered the conditions of rural life. The feudal services of the villein, bond or free, had over large areas of England become commuted for cash payment. In other words, agricultural rent had established itself in permanent shape, involving the theoretical freedom of labour and freedom of contract. Nevertheless, the fact that one of the demands in Kett's rebellion (1549) was the abolition of serfdom would seem to indicate that the disappearance of the bondsman was a process more gradual and protracted than is sometimes supposed.

The sudden stimulus towards better conditions of life thus afforded to the dependent classes was strongly accentuated by the 


\section{PROBLEMS OF VILLAGE LIFE}

terrible visitation of the Black Death in 1348. As a signal example of the inscrutable methods of Providence, a pestilence which destroyed from one-third to one-half of the population placed the labourer in a stronger position than he had ever secured before, or has ever secured since. The period which followed has been called the Golden Age of the English labourer. Never before or since was his pay so good or his power of combination so effective. Amid the widespread scarcity of labourers, wages rose, until in 1375 twice as much was paid for harvesting as was the case hefore the Plague. The day labourer in the fourteenth century received about a quarter of the market price of the farm produce : in the eighteenth, the proportion which fell to his lot was, according to Young, only one-tenth. A rising spirit of hope and courage drew the survivors of the great calamity together; and the efficacy of their combined efforts is apparent from the complaints of the ruling classes and the enactment of the "Statute of Labourers." In 1377 a protest was made by manorial lords, " as well as men of Holy Church," that " the villeins - . join themselves together in great routs and agree by such confederacy that every one shall aid them to resist their lords 


\section{STORY OF THE ENGLISH LAND 17}

with a strong hand:" and the re-enactment of repressive measures against the combination of workmen would appear to indicate that difficulty was experienced in the execution of such measures.

At first sight, it might seem paradoxical that a period when the peasantry had reached their high-water level of social betterment should be marked by the greatest agrarian revolt in English history - the peasant war of 1381. Moreover, it was in the most independent and most advanced part of rural England, East Anglia, that the fiercest outbursts of popular violence took place. "It has been noted," writes Professor Oman, "that peasant revolts all over Europe were wont to spring up not in the regions where the serf was in the deepest oppression, but in those in which he was comparatively welloff, where he was strong enough to aspire to greater liberty and to dream of getting it by force." The great German rising of $\mathbf{1 5 2 5}$ took place in districts where the burdens of feudalism were least felt. It is noticeable, too, that the most successful strike of recent years in rural England occurred not amongst the badly paid labourers of the South, but in a district of Lancashire where the average wages already reached the respectable figure 


\section{PROBLEMS OF VILLAGE LIFE}

of some 22/- a week. The desire for comfort and well-being becomes atrophied in time: the desolate and oppressed gaze dimly on such blessings " but not nigh, they behold them, but not now." It is only when freedom lies closer at hand that men will rush into the fray to secure it. . The rebellious peasants of the fourteenth century were inspired by a burning sense of social wrong and a zeal for freedom which flashed like a bright meteor trail across the sombre history of our English land and was lost once more in the surrounding gloom. The peasants, we are told by a contemporary, " affirmed themselves to be utterly discharged of all manner of serfage."

Nor must it be forgotten that amid the outward signs of betterment in this golden age certain basic facts of social oppression remained unshaken. A very large proportion of the villeins were still deprived of the full protection of the King's Courts : they were forbidden to sell their land or leave it without permission: unworthy and harassing dues and services, though gradually yielding to the force of custom, were still inscribed on the Statute Book. In the days of the great uprising the good "hedge-priest" Ball tells how "in the Eastern counties dwell men in four walls of wattled reeds and mud, and the 
north-east wind from off the Fen whistles through them: and poor they be to the letter : and there him whom the lord spareth the bailiff squeezeth, and him whom the bailiff forgetteth the Easterling chapman sheareth : yet these be stout men and valiant and your very brethren." Solid advantages had, it is true, been generally secured-freedom of contract, better wages and the practice of combination, but it was doubtless felt that what had been largely conceded to the force majeure of the Black Death and its results might be reversed under changed conditions. The peasant's advancement had been gained through special circumstances; he enjoyed no permanent guarantee for its continuance. The feudal system, no doubt, secured to the peasant farmers some measure of real freedom, but the latent possibility of evil inherent in the system became terrible actualities whenever the strong arm of the English kings was removed by civil strife. "No ghastlier picture of a nation's misery," says Green, "has ever been painted than that which closed the English Chronicle, whose last accents falter out amid the sorrows of the time," i.e., the end of the twelfth century.

The influence of the Church was not so uniformly on the side of the authorities during 
the earlier rebellions as in later periods of agrarian unrest. In the sixteenth century it was exceptional to find Churchmen like Latimer and Bernard Gilpin, who courageously denounced the despoiling of the rural poor, but during the earlier revolts considerable sympathy was extended to the peasants by many of the parochial clergy. It is true that monks like Thomas Walsingham and prelates like the warlike Bishop of Norwich were openly hostile to the rebels and followed the lines of Luther's later advice, that the peasants should be " strangled and, stabbed as a man would deal with a mad dog." Wyclif, moreover, stood aloof from the poor villagers in their struggle. But it is clear that many country parsons threw in their lot with their parishioners in the days of Tyler and Kett, and no less than three of the principal leaders were priests, John Wrawe, Straw, and John Ball. The extant sermons of Ball are full of touching faith and piety. "I have told you," said he, " of fellowship and ye have hearkened what the Holy Church is, whereby ye know that ye are fellows of the saints in Heaven and the poor men of Essex ; and as one day the saints shall call you to the Heavenly Feast, so now do the poor men call you to the battle."

Agrarian wars have occurred in the history 


\section{STORY OF THE ENGLISH LAND 21}

of nearly every European nation. In Germany the peasantry fought against their privileged and untaxed oppressors with brutal savagery, and hundreds of ruined castles serve to-day as memorials of the peasant revolts of the sixteenth century. In this case, as in England, the military skill and discipline of the governing class proved too strong for the bauern, whose risings were stamped out by reprisals of almost incredible ferocity. Nevertheless the German peasant. was never cowed by that long and systematic misery which has been well described as the Via Dolorosa of the English labourer: he succeeded in maintaining through the centuries some measure, at least, of independence.

The sudden frenzy of the French Jacquerie in the fourteenth century, with its peasant atrocities and terrible repression, was too local and short lived to exert any real influence on the subsequent fortunes of the rural population. The real agrarian revolt came to pass at a later and far more favourable time. When the long-suppressed fury of the peasants was let loose the landed aristocracy was hated by the urban as well as the rural inhabitants. The inspiration of American independence on the one hand and the menace of foreign intervention on the 
other knit the whole of France's democracy together, and the wonderful successes achieved by the raw troops of the Republic at Valmy and Jemappes bestowed a security of tenure and a civic status on the small owners of France which they have never lost.

While their brethren in other lands gained partial or complete successes the English peasants failed utterly and completely. In the three desperate risings of 1381, 1450 and 1549, they showed no lack indeed of courage and enthusiasm, but their ill-equipped forces were ultimately crushed by the royal levies or imported mercenaries. ${ }^{1}$ Good men and true like Tyler, Ball and Kett died in the midst of manifest failure, seeing the promise of better things from afar but not having attained unto them. Contemporary chroniclers combined to misrepresent and calumniate the peasants and their leaders, and nowadays the children of labourers in village schools are taught in current textbooks to ignore or condemn the men who died in a vain attempt to secure justice for the oppressed forefathers of the hamlet. It is indeed a bitter piece of historical irony that the exploits of Elizabethan buccaneers should be cherished while the very

s The Norfolk labourers were slaughtered at Dussindale by Italian infantry and "Alleman Horse." 


\section{STORY OF THE ENGLISH LAND 23}

names of Tyler, Kett, Wrawe, Cade, Straw, Ball and Grindecobbe have either passed into quasi-oblivion or are used as synonyms for a reckless adventurer or a ruffian. For the attitude of the governing classes towards the peasants at this period no modern parallel suggests itself except in the case of certain mixed communities of Europeans and negroes. The intermixture of hatred and dread which sometimes animates a white populace in relation to the blacks is reflected in the vocabulary habitually employed by chroniclers like Holingshed, Walsingham and Froissart when they describe the brave villagers of England.

The main causes of failure in the case of these peasant risings were the absence of able leaders and the lack of effective combination between the disaffected areas of the country. The removal of Kett's able leadership broke down all further resistance in Norfolk, despite several signal successes against the royal forces. The peasants who were massed on Blackheath were masters of the situation, but there was nobody to step into the place of Wat Tyler, their murdered leader. Never once in the whole course of English history did the monarch come forward to espouse the just rights of the poor villagers. Only once did 


\section{PROBLEMS OF VILLAGE LIFE}

a champion of the despoiled peasants emerge from the ranks of the greater aristocracy in the person of the Duke of Somerset, the "Protector" of young King Edward VI., and his sympathy. with the oppressed subjects of the king was undoubtedly his undoing. One of the comments in the indictment which brought him to the block was this :- "You said that the Lords of Parliament were loth to incline themselves to reformation of inclosures and other things; therefore the people had good cause to reform the things themselves." No writer of the period says a good word for the brave peasants who fought desperately with rude and inferior weapons against the foreign mercenaries whom the ruling classes imported for the slaughter of their own countrymen.

The peasant rising had ended in failure, but the times of stress and terror were not easily forgotten by the classes whose authority had been assailed. The general policy of these classes from the sixteenth to the eighteenth century appears to have been one of distrust and hostility towards the rural population. The Law, the Church, and social influences seemed to combine in order to crush out every spark of independence and every hope of advancement amongst our peasants. The 


\section{STORY OF THE ENGLISH LAND 25}

success of this conspiracy, one of the most efficient engines of human oppression that the world has seen, has left its mark only too clearly on the English village of to-day. It apparently transformed the whole character of our countrymen. In earlier days of English history the yeoman and the peasant, the men who fought at Agincourt and Crecy, who struggled desperately under Kett and Tyler, were described by Froissart as "le plus perilleux peuple qui soit au monde et plus outrageux et orgueilleux." But in the later centuries the glory of courage had, indeed, departed from the English countryside. The villagers were utterly cowed, fit ancestors of the men who were described by a Prime Minister of our own day as " afraid to call their souls their own." Advantages once gained were jealously preserved. By one enactment after another the villager was robbed of his Common rights, cheated of his wages, tied to the soil, denied all education and deprived of all hope. The harsh Act of Elizabeth's reign which enabled Justices to fix the maximum price of agricultural labour was tolerated by a submissive people until 1812. The Law of Parochial Settlement in 1662, which sought to prevent the movement of the labourer from parish to parish, fastened the chains of 


\section{PROBLEMS OF VILLAGE LIFE}

oppression more firmly. Thorold Rogers calls this measure "the worst Act of the worst Parliament which ever sat": but of all the great writers who lived during the long period covered by this measure, Adam Smith alone condemns it unreservedly. "To remove a man," he writes, "who has committed no misdemeanour from the parish where he chooses to reside is an evident violation of national liberty and justice."

The same influences which used the strong arm of the law in order to fix the labourer's wages and curtail his personal liberty combined in a continuous and successful effort to deprive him of his rights in waste and common land. The melancholy story of the Enclosure Acts is too long and complex for any detailed treatment in these pages. Much has been written in defence or condemnation of this policy and the controversy is not yet closed.

None of the writers, however, deny that, quite apart from the question of economic justification, the general result of the enclosure policy was to reduce a very large number of small farmers, rural workers and squatters to the position of landless and dependent labourers. The actual acreage of common land, waste or cultivated, which passed into private hands through the long series of 


\section{STORY OF THE ENGLISH LAND 27}

Enclosure Acts has been variously estimated. Mr. Prothero puts it at $8 \frac{1}{2}$ million acres, Mr. Arthur Johnson at 7,308,806 acres, of which $6 \frac{1}{2}$ millions were enclosed in the eighteenth or nineteenth centuries, no less than onefifth of the total acreage of England!

No doubt a case can be made out in defence of these wholesale enclosures. The minute subdivisions of common fields caused great waste of time and effort, and the cultivation was often careless and clumsy. The common pasturage again was in many cases quite inadequate and the squatters on the waste land were sometimes worthless and improvident poachers. The existence of a large tract like Otmoor in Oxfordshire, undrained, uncultivated, and good for little except the feeding of geese, represented a thoroughly uneconomic use of land; the general productiveness of the soil was certainly increased by the cultivation of land hitherto used solely for the poorest type of grazing or the provision of bedding, peat or firewood. Nevertheless, the fact remains that these enclosures were made not so much in the public interest as for the benefit of a comparatively small number of persons, many of them already in possession of large estates. The Rev. Arthur Johnson, in his admirable book, The Disappearance of 


\section{PROBLEMS OF VILLAGE LIFE}

the Small Landowner, declares that from the seventeenth century onwards "the Houses of Parliament, the central Executive, and the local bodies of administration all worked together towards a common end-the advancement of the interests of a great commercial and landowning aristocracy, . . . contemptuous of any opposition . . . and disregardful of any distress their conduct might cause."

The great campaign of pillage was carefully prepared by the very classes whose interests were served-the landlords who wanted more land and rent, the clergy who expected more tithes, the farmers who required more grazing land and disliked the independence of the smallholder and squatter. It was discovered that the peasant farmers were idle, vicious, and thoroughly undesirable: and religious cant was employed to prove that the "bounties of Nature ought to be revealed by putting God's land to its best use." "The use of common land by labourers," says the "Report on Shropshire," 1794, " operates on the mind as a sort of independence": when the commons are enclosed, "the labourers will work every day in the year, their children will be put out to labour early . . . and that subordination of the lower orders of Society, 


\section{STORY OF THE ENGLISH LAND 29}

which in the present times is so much wanted, would be thereby considerably secured." Because the cottagers and squatters preferred to work for themselves rather than others they were described as "incorrigibly idle;" their dwellings were held to be "instead of schools for virtue, most fruitful seminaries of vice."

The economic results of the Enclosure Acts pressed with pitiless severity upon the poor. Whole villages disappeared; the cottager's fuel had gone; in the absence of his small corn crop he was compelled to buy bread; with the loss of his common rights he lost the cow's milk for his children. The despoiled cottagers struggled fitfully against the encroachments, and the new fences were in many parts of England torn down again and again. But despite a certain amount of sympathy from the middle classes and even from the troops employed against them, ${ }^{1}$ the rioters-poor, badly organized, votelesscould offer no effective resistance to the legalised robbery of their rights and property. Until 1801, there was no appeal from the

1 I find a curious story in an old book on the Otmoor enclosures that the yeomanry who were employed to keep order, put smock frocks over their tunics at night and actually helped the rioters to demolish the fences ! 
decisions of the Enclosure Commissioners, who were in practice selected by the Petitioner. Even Young, an ardent advocate of enclosures, declares that the details were generally fixed by the landowners beforehand. "The small proprietor has little or no weight in regulating the clauses of the Act. The property of the proprietors, especially the poor ones, is entirely at the mercy of the Commissioners, for they are vested with a despotic power known in no other branch of business in this free country."

The tendency to add field to field and to increase the number of the large farms at the cost of the small ones, has continued through successive generations to the present day, and will be noticed later on as one of the causes which prompted the marked hostility of many landowners and farmers towards the policy of Small Holdings. With the disappearance of many thousands of small farms there disappeared also a class of men who had proved a mighty asset to the national safety and prosperity - the yeomanry of England, the men who had destroyed the knights of France in the days of Crecy and Agincourt. The disappearance of this highly valuable class of citizen has always aroused the amazement of foreign students of the English land 


\section{STORY OF THE ENGLISH LAND 31}

system. M. de Laveleye estimates that at the close of the seventeenth century there still remained 160,000 yeomen, forming with their families no less than one-seventh of the entire population. At the present moment this once powerful class is represented by a few scanty survivors in some of our more remote counties like Westmoreland and Somersetshire.

The most signal examples of the clearing process came from Scotland. The absorption of small farms and holdings, which has altered the whole condition of land tenure in the Highlands, had one remarkable feature. It was carried out in the midst of a hardy and independent race, which, in spite of the bitter wrongs of earlier days, retains a pathetic loyalty to the chieftains of the clans whose ancestors acted with the most callous disregard of their dependents' welfare. In the great "Sutherland clearings" of 1814-1820 some 3,000 families were expelled from their holdings and 800,000 acres of clan property annexed to the ducal domain. Such clearings have been excused on the grounds that the land was fit for nothing but rough sheepgrazing. But facts are too strong for apologetic generalities of this kind. A writer in the Economist (Jan. 2, 1886), quoted by M. 


\section{PROBLEMS OF VILLAGE LIFE}

de Laveleye, says, "The feudal owners are allowed to-day to act as freely as in the time when William the Conqueror destroyed thirtysix villages to make the New Forest. Two millions of acres, comprising land of the greatest fertility, are changed into a desert. The natural pasture of Glen Tilt was the richest in Perth, the deer forest of Ben Avieden fed 15,000 sheep, and we have here only the thirtieth part of the territory sacrificed or rendered so unproductive that it might as well have been swallowed up by the sea."

This process of absorption has been stereotyped in more recent days by the enormously enhanced value of shooting and fishing rights in the Highlands, and the eagerness of wealthy sportsmen, some of them of foreign nationality, to secure at almost any cost the cool solitudes of northern Scotland for the preservation on an immense scale of grouse and deer.

As Hasbach has pointed out, two great movements in English history, the Reformation and the struggle for the supremacy of Parliament, proved, by a sad paradox, full of mischief for the villagers of our country. The suppression of monasteries and the seizure of monastic estates, one-fifth of the total area of the cultivated land, deprived the poor of the succour which had hitherto supported 
them in sickness and destitution. On the other hand, the triumph of Parliamentary Government stereotyped for centuries a class domination which wasted the lives and earnings of the poor in reckless wars, deprived them of their land, sapped their independence, and denied them any share in the government of their country. The laws, as a village catechism of Devonshire puts it with brutal candour, were established to "safeguard the rights of property and control the vicious poor."

Under the "Speenhamland" system of "allowances". at the close of the eighteenth century, the English labourer reached the low-water mark in the sad history of his organized degradation. The subsidizing of cheap labour from the rates enabled the farmer to pay sweated wages from the pockets of the general public whether employers or not. The agricultural labourer became a pauper by law. Nevertheless the actual motive which underlay this clumsy and vicious system was a sound one. The conscience of England was very slowly being aroused by the hopeless poverty and demoralization of the agricultural labourers and the general decay of the countryside. Appalling misery was inflicted on the poor by high protective 
tariffs. In 1801 wheat rose to $128 / 6$ a quarter, and from 1805-1813 the average price was $100 / 4$ ! Nor was it the labourers alone who suffered, for the contemporary testimony of Cobbett and others depicts not only the deep penury of the poorer folk but the widespread ruin and bankruptcy of the farmers, the increase of derelict land, the decay of agriculture ; the landowners alone flourished.

The nation seemed to realize at last that something must be done, and the nineteenth century was a period of palliative legislation for the crying needs of the English village. In 1812 the claim of the magistrates to fix the rate of wages was abolished and twelve years later the laws directed for five centuries against the right of combination were finally abolished. ${ }^{1}$ Nevertheless the old spirit of repression was still in evidence amongst the governing classes of the countryside. Whatever sympathy was extended to the labourers during the futile rising of 1830 , a last feeble echo of the Peasant Revolts, came apparently from the towns. The rioters, described by

${ }^{1}$ A statute of Edward VI. punished by fine of $£ 10$ or twenty days' imprisonment any combination of labourers "concerning their work and wages," and at the end of the eighteenth century labourers were liable to severe penalties, including transportation, if they combined to demand an advance of wages. 


\section{STORY OF THE ENGLISH LAND 35}

the Times (Dec. 6th, 1830) as " industrious, kind-hearted, but broken-hearted "beings, exasperated into madness by insufficient food and clothing," were treated with a harshness which eighty-three years afterwards is scarcely conceivable. No life had been taken during the "Swing Riots": nevertheless, nine men and boys were hung, at least 450 men and boys were transported, and 400 suffered imprisonment in the local gaols. Here and there in Oxfordshire, Wiltshire, and Berkshire I have come across very old men and women who still remembered the frenzy of horror and grief produced in the villages by these appalling penalties, for of those transported to Australia and Van Dieman's land, only about one in six returned.

The extension of the franchise in 1867 encouraged the labourers to make another effort in the days of Joseph Arch and the Union. Some advance in their miserable condition was, it is true, secured, but the same lack of cohesion and independence and sustained effort-the outcome of the long centuries of oppression and neglect-again prevented the men from reaping the proper fruit of their just discontent. By the end of the nineteenth century the labourer had generally relapsed into apathy and hopelessness. Deprived of 


\section{PROBLEMS OF VILLAGE LIFE}

any real opportunity of securing an independent livelihood, with nothing before them except the miserable wages of a farm hand and pauperism at the close, the landless villagers turned their thoughts more and more to the towns, and that rural exodus commenced which continues to this day and has drained away the best and most active life of our countrysides. 


\section{CHAPTER II}

RURAL ENGLAND OF TO-DAY

Despite the great variety of the conditions which prevail in our rural districts, it is possible to distinguish certain broad outlines and to make certain generalizations; and it is with these that a book such as the present must necessarily deal. Agricultural England is very far, of course, from being homogeneous. What is true of the dales of Yorkshire may not be true of the downs of Wiltshire, Hampshire, and Sussex; and the student of the arable districts of East Anglia may find himself almost in a new world when he comes among the stock and dairy farmers of the Western counties. The agricultural labourer of the North earns considerably higher wages than his brother of the South, and shares, to some extent, in the self-confident and independent character of the artisans of great industrial towns. The Southern labourer is the child of an older civilization, more conservative, more humble, more easily cowed, more 


\section{PROBLEMS OF VILLAGE LIFE}

inarticulate; and the habits engendered by the feudal system are more deeply ingrained in his mind. He plods slowly on in the ways which his forefathers have trodden for uncounted generations. In some localities the position of the agricultural labourer is improved through his proximity to well-paid work in neighbouring mines, docks, factories, etc.

But, however districts may vary, a single type of society prevails in all of them. There are, of course, dangers in that sharp definition of classes which writers on social subjects are tempted to adopt for the sake of simplicity and emphasis. But those who will contrast rural England with rural Italy, Germany, or France, or who will consider the infinite and bewildering gradations of our urban society, will not quarrel with the customary division of the country population into landowner, tenant-farmer, and labourer. The three classes overlap but slightly, and they form the fundamental elements of the social structure. The land agent, the minister of religion, the country solicitor and doctor, the dealer in farming requisites of one kind or another, the publican, the carpenter or blacksmith, the miller and the village shopkeeper-these only exist to serve the needs of the three main 


\section{RURAL ENGLAND OF TO-DAY 39}

classes. Distinct industries of an essentially rural character, such as malting, are not numerous enough to claim separate treatment in a survey such as this.

There is, indeed, one section, now increasing with ominous rapidity, which deserves passing mention. This is the class which ministers exclusively to the pleasures of the rich, whether by tending their horses, maintaining their gardens and parks, or preserving the everincreasing stock of wild and hand-raised game which occupies so prominent a place in our rural economy.

Free Trade, with the vast improvements in cheap and rapid transit, struck a heavy blow at the fortunes of the landlord class. Since the days of the Corn Laws rents have fallen 50 per cent. and more, and the houses built, the style of living instituted, and the social habits acquired, in a period of great prosperity, have in some cases become a serious burden. Proprietors of land which is entailed, heavily mortgaged, or charged with family payments, are often in a peculiarly hard case. Like the rest, they are suffering from the rapid changes brought about by the alteration in our fiscal system; but the improvidence of their predecessors has closed to them the means of escape. The inflated prosperity of 
the early nineteenth century placed the landlords in an artificial position, which could not reasonably be secured to them in perpetuity. If such wealth and such power could ever be rightly confided to so minute a section of the people, it could only be in return for some great and outstanding service, such as the feudal landlords rendered, before the seventeenth century, by bearing the whole burden of the national defence. The change was inevitable. But we cannot disguise from ourselves the hardships which have accompanied it.

Much controversy rages round the merits or demerits of our country landlords. There are certain things which are alleged in defence of their social ideal. They are expected to be, and often are, dispensers of charity on a large scale. They help to support churches and schools, subsidise local societies, distribute food and clothing. They man the magisterial bench. They render laborious and unpaid service on the local councils. Where they have resources other than those derived from their land itself, they put a considerable amount of capital into the soil, often without receiving or expecting a commercial return for it. About one-fifth of the net agricultural rent of England and Wales is, it is said, 


\section{RURAL ENGLAND OF TO-DAY 41}

interest on capital, and not, in the economist's sense, rent at all. So far as the capital expenditure is concerned, the landlord is simply a partner in business with the tenantfarmer. The large landlord, again, is frequently able to grant remissions of rent, or to wait for its payment, where a more necessitous or more greedy type of owner might press hardly on the tenant. The system of large estates, whose business is transacted from a central office by a highly-paid, though often indifferently-trained agent, has some advantages in continuity of management and the wider outlook which comes of dcaling with large sums of money and large numbers of men. Again, the relation of a large landowner to the tenants and labourers of his estate, though frankly that of superior to inferior, is generally of a friendly and a personal nature.

There is, further, one institution whose maintenance entirely depends on the country landowner. Sport, apart from the farmer's occasional rabbit-shoot, would die out if it were not for the great houses. At present, whatever may be said against these pursuits, either on humanitarian or economic grounds, they certainly fill an important place in the tradition of the countryside. Hunting, in par- 


\section{PROBLEMS OF VILLAGE LIFE}

ticular, provides a not inconsiderable section of the people with interest and recreation.

In estimating the usefulness, on public grounds, of the large landowners, many things must be taken into account which do not, perhaps, appear on the surface. The wholesale distribution in one form or another of food, clothing, and entertainment, is a poor substitute for prosperous industry, though over large parts of the country it wins unbounded admiration for those who practise it. Thousands of our poor village folk seem unable to conceive any greater virtue in their superiors than open-handedness, and nothing but satisfaction is felt on either side. None the less, the need for all this charity might be avoided by a wiser policy; and its effect is to make the agricultural labourers year by year less capable of standing by themselves. The establishment of friendly relations between different classes is a gain. But, on the part of those who profit matcrially by this great system of charity, the friendly relation is too often largely inspired by gratitude for past gifts and the hope of advantages to come.

Such a social ideal reacts, naturally enough, upon the business methods of those who live under its influence. Unlike an ordinary commercial enterprise, a great estate is not 
RURAL ENGLAND OF TO-DAY 43

conducted with the primary object of "paying." There are certain obvious advantages in this from the point of view of the farming tenant in a bad season. But the absence of economy and the absence of business ideas mean that the land is not used in the most profitable way. Any question of improvement, whether in respect to housing, farm buildings, waste ground or woodland, is frequently regarded from other points of view than those of economic management. Much expense is incurred for which the land itself, and the character of the farming, afford no warrant. Complaints are often heard of the impossibility of obtaining a commercial return for capital spent in cottage building and the like. The answer is supplied by what has been said above. The money is seldom spent on the same principles as those by which ordinary business men guide their conduct. In many instances the real return which is aimed at, consciously or unconsciously, is social standing, the dignity attaching to a large estate, good shooting and fishing, the absence of unsightliness, the amenities of country-house life. It is precisely these considerations which sometimes render large estates an attractive investment in the eyes of wealthy men, who regard the land not as 


\section{PROBLEMS OF VILLAGE LIFE}

the raw material of sound business, but as the delectable pleasure-ground of a fortunate minority. This type of land-absorption accentuates the evils of the countryside; it is a case, as Mr. Rider Haggard would say, of the land being supported by men rather than men by the land.

The system of large estates provides special difficulties in the creation of -small holdings. The small holder breaks up the country into minute divisions, and in some cases injures it from the point of view of the scenery. He gives a considerable amount of extra trouble to the agent, who prefers to collect his rents and to carry out his various dealings and negotiations among a smaller number of substantial tenants. More than all, and this is a really serious difficulty, the small holder has generally a rooted objection to any shooting or hunting on his piece of land. $\mathrm{He}$ is particular about trifling losses. He complains more loudly than the large farmer of the damage done by hares and rabbits to his small but closely-tended crops; of the turnips grazed by the sportsman's boots in September; of the gaps made in his fences, and the deep hoof marks in his fields, where, on the heavier soils, the water may stand for days. He is not likely to be propitiated, like 


\section{RURAL ENGLAND OF TO-DAY 45}

the large farmer, by an occasional invitation to a day's shooting; and, as he does not hunt, or even do a little dealing in hunters, he has scant sympathy with those who find time for such pursuits.

The highest types of farming cannot well exist side by side with extensive game preservation; and the successful agriculturists of France, Italy or Belgium regard with amazement the general attitude of passive resistance or willing acquiescence taken up by our farmers towards the patrons of sport. Terrible havoc is sometimes played with young crops by rabbits issuing by night from coverts over which the farmer has no control. Pheasants pull up young corn to get at the seed, and at times inflict cruel losses on small holders in shooting neighbourhoods. In the case of injury to crops, hedges, and poultry by fox-hunting, the subscribers of some hunts, it is true, pay many hundreds a year in direct compensation to farmers, besides what is spent on puppy shows and other functions, which help to conciliate those who make a living out of agriculture. These things and an occasional invitation to a 1/6 luncheon may satisfy the farmer; but they imply a considerable economic loss to the nation, both in the actual injury done, and in the pro- 


\section{PROBLEMS OF VILLAGE LIFE}

motion of the idea that the country is to be treated as a playground.

It is difficult to obtain accurate figures, but it is clear that an increasing quantity "of land is being kept partially or wholly for sport. This is done by landlords who either can afford to do without their rent and to incur considerable expense in addition, or else find that the sporting rent obtainable is as high as, or even higher than, the agricultural. In the latter case, they cannot be condemned from the business man's point of view ; but, from the point of view of the nation, the consequences are obviously disastrous. Land which might be used for productive purposes is farmed but carelessly, or left altogether idle. The economic resources of the country run to waste, and gradually deteriorate. The general results are deplorable enough in the case of landowners who fill a definite position in the social life of the country. But, as a matter of fact, and more particularly in the south of England, an increasing number of the owners who make sport their main object are men who have made their money in business, who use their country houses as hunting or shooting boxes, and who do not recognise, as attaching to the privileged position of landowner, any especial duty towards the local population. 
The influence of the landlord, both for good and for evil, is vastly increased by two things : the great preponderance of his class upon the local bench, and the fact that, as a general rule, he alone among his rural neighbours can afford to be a member of the County Council. These things account for much of the importance popularly attached to his wishes and his example. The result is that the services he renders in these capacities are largely neutralised by the class and party colour with which he invests the institutions concerned. The local bench, which to the countryman's mind represents, far more than Quarter Sessions or Assizes, the machinery of justice, is not regarded with the confidence that is felt, let us say, in the lawyer-magistrates of the towns. If it is treated with respect, it is the respect due to power rather than impartiality. Similarly, the County Council is not, and is not felt to be, a democratic or representative body : so long as it is practically impossible for a labourer, or for any but the largest farmers, to sit upon it, it is not likely to become so.

One further fact remains to be noted. This is the influence exercised by the landlord class at elections. So great and widespread is the power exercised by a landowner over the 


\section{PROBLEMS OF VILLAGE LIFE}

fortunes of tenants and employés of every kind that even his expressions of opinion, unless counteracted by explicit declarations of impartiality, affect large numbers of votes. Some are strong enough to resist this influence ; but a large number, who are not prepared to sacrifice much for their convictions, and who are destitute of the pride and independence engendered by trades unionism and other forms of combination, are inclined to take the easier course. They abandon all attempt to make up their minds for themselves on reasonable grounds, or to maintain courageously the opinions which they have formed. This influence is reinforced by the personal ties and the widespread charity to which reference has been made. It is often exercised with little consciousness of the pressure which it involves. On the other hand, there are not a few who, taking a strong line in politics, do not hesitate to use to the utmost extent the power which their position gives them of influencing votes on non-political grounds.

In a word, the power wielded by the landlord class is immense in all spheres-the social, in which they set the standard for all classes; the economic, in which they dictate the methods of production; the political, in which they control the expression of opinion. 
There was a time when their possession of such power was normal and inevitable. So long as all their interests were centred in their own neighbourhood, and the country house was not a mere place of retreat after the London season; so long as they shared with the clergy the monopoly of education; so long as they were the only possible administrators of justice, the only possible legislators, the only possible leaders in social life and opinion; so long as rural society was too little developed to dispense with autocratic government; so long was it natural that they should control the destinies of the countryside. But, in so far as these conditions have ceased to exist, the powers and privileges of the English landlords have lost any justification they ever possessed. Privilege, however, dies hard in the midst of so conservative a people as the English, and the chains of Feudalism are still riveted firmly upon our rural districts. Even under a Liberal Government, the administration of the Small Holdings Act, the dispensing of justice, the control of our Territorial battalions have all been committed into the hands of the landowning class, to an extent which makes the country voter sometimes ask himself whether there is really much difference between one Government and another. The stream 


\section{PROBLEMS OF VILLAGE LIFE}

of feudal control flows on as steadily as everRusticus expectat dum defluat amnis.

The same fiscal changes which so profoundly affected the landowners made a considerable difference, also, to those who actually farm the soil. But it is a matter of controversy whether the financial position of our tenantfarmers is materially worse to-day than in the period of protective duties. A fall in prices does not necessarily injure the farmer, provided the land still yields a living. Whether it so injures him or not depends upon the question whether his rent has been reduced sufficiently to meet the new conditions. The farming accounts presented to the Royal Commission on Agricultural Depression would seem to show that in many parts of the country, great as has been the reduction in rents, it ought to have been greater still. But on the whole the rents demanded nowadays are probably not very much in excess of what the tenant-farmer can afford to pay while making a moderate living for himself. And, in the case of some more generous or more careless landlords, the tenants might perhaps appear to be rather under-rented than over-rented.

Much depends, again, on the extent to which the farmers of England as a whole have adapted themselves to the changes which 
have occurred in the profit obtainable from different crops or methods of farming. Corngrowing and cattle-farming on a large scale have become relatively less profitable, while the supply of milk-an article unaffected by foreign competition-has been immensely developed during the last ten years. The growing of potatoes and other vegetables on small farms, poultry keeping, and fruit culture have all received increased attention.

On the whole, except where farmers are burdened by debts inherited from less prosperous years, or where they have started with insufficient capital, they are making a fair living, though they are not amassing fortunes. Much depends upon the standard of living to which farmers, like other people, are practically compelled by the public opinion of their class to conform. Many of the complaints which are heard are in reality founded on the difficulty which farmers experience in maintaining a scale of personal expenditure approaching that of the wellto-do tradesman, solicitor, or bank manager in the country town. Working farmers who are content with a little-and particularly the Scotch and West-country farmers, who have so largely invaded the south and east of England-are not doing badly. At any rate, when 


\section{PROBLEMS OF VILLAGE LIFE}

farms are to let there is seldom any lack of applications. The farmers' grievance against the burden of the rates has not been assuaged by the fact that he alone in the community has half his rates remitted by the State; nor does he adequately appreciate the fact that the farmer who pays income-tax is a rare phenomenon. Even a tenant paying as much as $£ 480$ a year in rent is exempted from an impost levied upon persons who live in far less comfort than himself.

A more substantial grievance of the farmer arises from the conditions of tenure under which he holds his land. It has long been recognised that the relations of the agricultural landowner and his tenant cannot be left to the stress of mere competition. But the security hitherto given to the tenant is exceedingly small, and when a farmer has no fixity of tenure he is deprived of a powerful motive for making the most of his farm. Compensation is granted to an outgoing tenant according to somewhat arbitrary rules devised by the valuers, for certain manures, feeding stuffs, repairs, etc. But no recognition is given to the fact that by continuous good farming, or the reverse, a tenant may increase or diminish the value of the farm to an extent which cannot 
be measured by the mere value of such "improvements"; and, as matters stand, there is no premium for the increase and no penalty for the decrease. Nor is there, further, any security against over-renting. The Agricultural Holdings Act of 1906 brought much needed relief in certain particulars. Before its passing, a farmer might be and frequently was put to considerable expense through being evicted from his farm for some cause other than bad farming or non-payment of rent; he could obtain no compensation for damage by game unless it was provided for in his lease; and he was hampered by excessive restrictions on freedom of cropping. But some of the advantages secured by this Act are in practice more apparent than real.

The unjust conditions under which tenantfarmers suffer arouse no great amount of open resentment; partly because the farmers know that their landlords have themselves in some cases lost heavily and are generous enough to sympathise with them, but perhaps still more because they have few organizations of their own through which they can express and enforce their wishes. Deficient in the power of combination, and easily led by social inducements, they can seldom be drawn into farmers' clubs, or Chambers of Agriculture, 


\section{PROBLEMS OF VILLAGE LIFE}

except by the enterprise or public spirit of members of the landlord class. As is only natural, the men who found, finance, and conduct these institutions, do all they can to preach the identity of interest between owner and tenant, concentrate attention on neutral subjects, and divert it from questions of rent or tenure. In the series of questions addressed to Parliamentary candidates by Chambers of Agriculture, a large number of points are usually raised, ranging from religious instruction in elementary schools down to the worrying of sheep by stray dogs. Very rarely does one find a question referring either to rent or to tenure.

Though agriculture may, therefore, to some extent be described as a " burdened industry," it cannot be said that farmers are failing to make a living out of the soil or to secure a fair return, which might, perhaps, be put at $\mathbf{1 0}$ or 12 per cent. on the average, from the capital which they invest in their business. But this does not by any means imply that the land of England is being cultivated to the best advantage. On the contrary, there is a widespread opinion in almost every county that the condition of the land is going back rather than forward; that in too many cases little more is being done than scratching the 
surface; that the increased use of machinery is very far from compensating for the skilful labour which is brought to bear on the capabilities of the soil in France, Denmark or Belgium.

The prosperity of English farming is handicapped at the start by the fact that four classes-landlords, clergy, tenant-farmers and labourers-derive support from the soil. This disadvantage is accentuated by the absence of serious purpose in the pursuit of agriculture. To go no further, it is notorious that young Englishmen who, through idleness or incapacity, are quite unfitted for any ordinary career, are frequently regarded by their parents as likely to succeed in agriculture. "Being a pupil in Denmark," writes Mr. A. W. Taylor, "does not mean that a young man allows his father to pay a high premium for him, and then lounges about on horseback or on foot and shoots rabbits and shirks his work, as too often happens in England. Danish pupils do ordinary agricultural work, cart manure, milk the cows, dig, plough, and sow. In a word, they earn their wages by the sweat of their brow like ordinary labourers. All these things a Danish farm pupil does, even if, as in a case which I know of, he happens to be a member of the royal family." 


\section{PROBLEMS OF VILLAGE LIFE}

What is the result of this business-like attitude towards the farming industry? With a less fertile soil, a similar wage bill, lower prices for produce, a worse climate and Free Trade in foodstuffs, agriculture in Denmark is infinitely more prosperous than it is in England.

Over the greater part of England, farmhouses are situated at a considerable distance from one another, and this simple fact is perhaps at the root of the peculiarities of character which most observers agree in attributing to the English farmer. His aim is to be master in his own house, to manage his affairs without interference from outside, and to let no one know how he is doing it. $\mathrm{He}$ is suspicious of others, and takes a pride in maintaining towards all enquirers a close and baffling reticence. Only on one subject is he communicative, and that is the decay of agriculture and the unjust advantages enjoyed by the townsman, whose profits he imagines to be on a vastly higher scale than his own. $\mathrm{He}$ is individualistic to the core-a laudator temporis acti, who sighs for the "good old times" when wheat sold at $60 /-$ a quarter and labourers lived semi-bestial lives on 8/a week. The District Council and the Board of Guardians provide the sphere in which he 
takes his part in local government. In the hierarchy of office he thus occupies a middle position between the landlord, who sits on the County Council, and the labourer who cannot drive to the market town, but who can trudge to the meeting of the Parish Council in the village schoolroom. The standard of living which, as a general rule, he tries to maintain is something between that of the gentry and that of the "common people." In the Northern and North Midland counties a somewhat humbler mode of life prevails ; but the statement is broadly true if an average be taken over the whole country.

Two pleasant characteristics of the English farmer are his open-handed hospitality and his readiness, however deep-rooted his prejudices, to appreciate in a political opponent that indefinable British quality connoted by the phrase "good fellow" or " good sportsman." Many of our tenant-farmers indulge in a disproportionate outlay of time and money during weekly visits to the neighbouring town, when the corn-exchange and the cattle market, the substantial "ordinary" and the generous treating of friends afford a welcome change from the monotonous existence of a solitary farmstead.

In matters of food, clothing and furniture, 


\section{PROBLEMS OF VILLAGE LIFE}

the farmer expects and enjoys substantial comfort. A maid-servant in the house, a piano in the parlour, a neat dogeart, a hunter or two to be sold at a profit and now and then to be ridden to hounds-these are things which the much-abused soil of England is expected to yield, and not infrequently does yield, to those who superintend its culture. The farmer's daughters are less and less inclined to help in the work of the farm, and turn more and more to pursuits which yield a higher degree of social consideration. Between the farmer's family and the agricultural labourer's a sharp line is drawn. To this "distinction the farmer clings tenaciously. Often he works with his men and associates with them on terms of hearty goodfellowship. But he thinks that they get more than they deserve. The suggestion of a minimum wage moves him to indignation. $\mathrm{He}$ ridicules the idea of the labourer turning farmer on his own account. His attitude, indeed, closely resembles that of his landlord towards himself. "Let us be friends if possible. Let us stand in with each other all we can, but you must know your place and keep it." 


\section{CHAPTER III}

\section{THE RURAL EXODUS}

IN dealing with the agricultural labourers a warning against generalization is needed most of all. More even than in the case of the landowner and the farmer, we must remember that many local varieties are necessarily left unmentioned in a survey such as this.

In discussions concerning the farm labourer stress is sometimes laid on the admitted fact that his condition has improved considerably during the nineteenth century, and that in consequence he is usually "quite contented, if only he is left alone." These beliefs are doubtless encouraged by the stolid endurance and amazing patience of an almost inarticulate class. But even granted that the labourer is more prosperous than he was-granted that milk and groceries and, at times, butcher's meat are found nowadays on his table, it is at any rate clear that these added comforts 


\section{PROBLEMS OF VILLAGE LIFE}

and humble luxuries are not enough to induce him to stay on the soil.

Politicians and sociologists of every school of thought have since 1851 admitted the alarming decrease in the numbers of our rural population. A slight improvement has taken place during the opening years of the twentieth century, for actual diminution has been replaced by a slight increase. If we take the "rural districts" of the Census returns, we find a positive addition to the population of 438,066 in ten years; but side by side with this small augmentation of actual inhabitants the urban population has been added to at a much higher rate, with the result that the actual proportion of rural dwellers to the older population has reached its lowest point of 21.9 per cent. Further, in the case of 581 rural parishes which showed considerable increase of population, Mr. Seebohm Rowntree discovered that only sixteen attribute the growth to agricultural development. The causes of the increase in the remaining 565 parishes are declared to be residential developments in the neighbourhood of towns, the building of factories, the extension of collieries, and other matters wholly disconnected with agriculture. If, again, we take the numbers of those in England and Wales actually 
engaged in agriculture as labourers and shepherds we are faced by the following figures :-

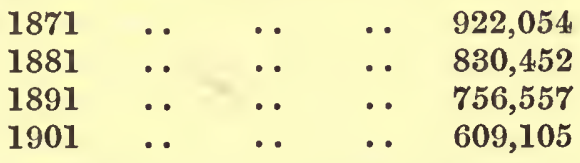

(Figures for 1911 not yet available.)

The cultivated land of England and Wales is worked by twenty-eight males per square mile (Census of 1901). If we used our land like that of Belgium with her seventy-two workers per square mile, we should increase our rural population by nearly two millions !

The most important of our national industries is being starved for want of adequate workers, but for the nation as a whole the fact possesses only a feeble interest. The sinister significance of deserted villages and a failing food supply is hidden from the eyes of our urban population by politicians whose acquaintance with the country is often derived from week-end house-parties and rural golf links. Transit by land and sea is so rapid and cheap that as long as Danish butter can be bought at 1/- a lb., and Servian eggs at $1 \mathrm{~d}$. each, and New Zealand mutton at 6d., the British householder takes little notice of the fact that all these things and more also should 


\section{PROBLEMS OF VILLAGE LIFE}

under normal conditions be produced on our own farms. Students of sociology do, it is true, point out in absolutely convincing language the evil effects of urban overcrowding due to the incessant influx from country areas. Physiologists tell us that a healthy family which migrates into a city rapidly deteriorates in the changed environment, and rarely persists beyond the third generation. Military students point out that 100 years ago some 75 per cent. of the British army was recruited from our rural districts, and refer with alarm to the well-known fact that in 1900 out of 11,000 applicants for enlistment at Manchester only 1000 reached the standard required for the Regular Army. ${ }^{1}$

Farmers lament the departure of the most active and intelligent young men. There are whole stretches of territory in Great Britain where alert youths of sound intelligence are the exception rather than the rule. Mr. Hueffer discovered from a careful investigation that on eighteen farms covering an area of eight square miles only five boys found employment and all of them were below the normal intelligence. In forty-six labourers'

1 A favourite argument in Germany for the Junkers" policy of protective duties on farm produce is the necessity of getting sound young men for the Kaiser's army. 
families he found only two youths still at home, and his general conclusion is that in general only about 5 per cent. of the boys elect to stay in the parishes where they were born. The migration of the village girls is still more marked; for economic and other reasons they flock to "service " in towns and the young men follow these playmates of their boyhood.

This phenomenon of rural depopulation is not confined to Great Britain. The rural inhabitants of countries so diverse as, to go no further, Germany, Italy and the United States, are gradually migrating to urban centres or distant lands across the sea. In the New England States there were a few years ago, according to Mr. Pratt, no less than 26,000 derelict farms. The influence of the agrarian party in Germany is enormous, nevertheless there has been a steady diminution in the rural population. In 1830,80 per cent. of the people worked in the country; in 1895 the proportion had sunk to $\mathbf{3 5 . 7}$ per cent. During the last twenty years, while emigration from Germany has diminished, increasing numbers of men are attracted from the rural districts by the vigorously developed industries of the towns. More than one-fifth of the entire population now live in towns of over 100,000 people. Italian statesmen complain that 


\section{PROBLEMS OF VILLAGE LIFE}

their industrious peasantry is being constantly drained by emigration to the Argentine and the United States; and even the barren hinterland of Tripoli is held out as a refuge from the intolerable conditions of village life in the peninsula.

While the great majority of our labourers who abandon the country districts find their way into the towns, an increasing stream of emigrants leave the villages for Canada, Australia and the United States. According to Mr. Rowntree the emigration figures for adult agricultural labourers have risen from 9000 in 1906 to 33,000 in 1911 - which means that "about one out of every forty agriculturists found his prospects in this country so poor that he decided to quit the country altogether."

The facts then of rural depopulation are patent and undisputed : and the significance of this "exodus" is especially serious amongst ourselves. An insular nation, liable by the fortunes of war to be cut off to a greater or smaller degree from sea-borne food, seems undismayed by the reflection that its available supplies would not extend beyond two months, and that long before that limit were reached a state of almost unthinkable misery would supervene in the crowded streets and slums of 


\section{THE RURAL EXODUS}

our cities. The typical citizen of most countries is the man who tills the soil : in the most fertile country of the globe, he is of all classes the most insignificant and the least endowed with social or political influence.

The causes of the rural depopulation in England are various and complex. The most powerful of them is the poverty of the agricultural labourer, who may be described in summary as a poor man living in a poor home on poor food. His wages have for forty years been practically unchanged, while the cost of living has actually increased in the last two decades.

When everything is included in the estimate which can be-harvest and hay money, allowances for lambs and calves, grants of potatoes, free cottages, and so on, the averages work out as follows-

$\begin{array}{lcccc}\text { Ordinary labourers } & \ldots & \ldots & 17 / 6 \\ \text { Men in charge of horses } & \ldots & 19 /- \\ \text { Cattle men } & \ldots & \ldots & \ldots & 19 / 3 \\ \text { Shepherds } & \ldots & \ldots & \ldots & 19 / 7\end{array}$

Sixty per cent. of our ordinary agricultural labourers in England receive less than 18/- a week, all included.

But there is one feature in the above estimate of agricultural wages which is too 


\section{PROBLEMS OF VILLAGE LIFE}

lightly regarded by the apologists for the existing scale, viz., the inclusion of overtime rates. Harvest money and hay money are payments made for abnormal effort, and in most cases long hours of overtime. If the spokesman of a Farmers' Club or Chamber of Agriculture points to an extra payment of

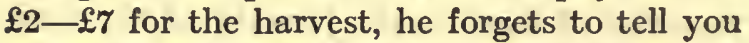
that under decent conditions of weather his men will begin their work the moment the dew is dried and continue it long after the sun has set. Sometimes you will see harvesters hard at work till ten or eleven o'clock in the evening. If we leave overtime and special "allowances" out of the calculation the normal wages of the agricultural labourer in England sink to a still more miserable level-

\begin{tabular}{|c|c|}
\hline \multicolumn{2}{|c|}{.. $14 / 9$} \\
\hline Ien is & of \\
\hline Cattle men & .. \\
\hline hepherd & .. \\
\hline
\end{tabular}

In the south midland, south-western and eastern counties, the average wages of an ordinary labourer do not exceed 13/6 a week, and in Oxfordshire, the worst paid county in England, sink to 13/-! Even in districts where the competition of factories, mines, docks, etc., tends to raise agricultural 
wages, the average weekly rates of cash wages for ordinary labourers never exceed 18/8, nor, with all allowances included, 20/5! The best paid labourer, the shepherd, secures, including allowances, 23/6 in Cumberland and Westmoreland, 20/9 in Yorkshire, Lancashire and Cheshire, and everywhere else in England under a sovereign.

The economic facts of village life are to some extent concealed from the public-or that small portion of the public which evinces any interest in the subject-by this unsatisfactory system of allowances in kind, allotment ground, rent-free cottages, and the like. Such methods of augmenting inadequate cash wages are thoroughly unsatisfactory, for they virtually represent a system of doles which tends to destroy the just independence of the labourer, nor would they be tolerated by any well-organized body of British workmen. No reasonable student of rural economy can avoid the conclusion that agricultural wages are cruelly inadequate, or wonder at the diminution of the rural population caused by migration to our cities and colonies. One simple calculation will impress even well-todo exponents of the doctrine of contentment with the severity of life's struggle in many a village home. Take an average family of 


\section{PROBLEMS OF VILLAGE LIFE}

five, and allow each member of it one penny for each of his or her three meals a day. This is not an excessive demand-many animals receive more than this-but it means $8 / 9$ a week for the family. An Oxfordshire housewife would, then, have some 4/-left for clothes, boots, coals, oil, insurance money, and so on, including, in many cases, $1 / 6$ to $2 /-$ for the rent. The wives of our poor villagers show real ability in the management of their humble budgets, but all said and done, what room is there for the joy or amenities of life in such an environment? "It's not living, sir," I have often been told, "it's only pinching and starving." Nor is there anything in the character of farm-work which should necessarily condemn it to so inadequate a recompense. The current description of it as "unskilled" is most misleading, and even were the term justified one may fairly ask why a docker or a bricklayer's labourer should receive so much more a week than an efficient farm-hand. The latter understands ploughing, ditching and draining, the care of animals, and the other tasks which make up the day's work on a farm. This is very far from being unskilled work, and requires infinitely greater ability and experience than carrying mortar up a ladder or wheeling boxes along a quay. 
The cottage question in general, and the tied-cottage grievance in particular, are powerful factors in driving townwards the population of our villages.

The basic facts of the housing problems are these. A large proportion of our rural cottages are, in the words of a Royal Commission's Report, "vile and deplorable dwellings," built without any adequate regard for sanitation or the air supply necessary for healthy sleep. It is impossible here to deal with the cumulative and irresistible evidence which proves the case; it must suffice to quote some facts which are typical of the housing conditions of very many English villages.

A recent enquiry at Potterne, in Wiltshire, revealed some shocking facts of overcrowding. In some two-bedroomed cottages slept six and seven adults, and nine to ten persons in all ; in one case the two rooms were occupied by two families and a young man lodger. There were in this village twenty-nine onebedroomed cottages, in several of which five or six persons were sleeping. The medical officer of health reports that he was obliged to accept 200 cubic feet per head of sleeping accommodation as his standard, i.e., twothirds of the minimum space compulsory in the case of common lodging-houses. 


\section{PROBLEMS OF VILLAGE LIFE}

The casual visitor to our rural districts is frequently led by the picturesque exteriors of our country cottages to ignore the existence of the damp and squalid accommodation within. Mrs. Allingham's charming sketches of " the cottage homes of England " must not blind us to the fact that the general standard of rural housing is disgracefully low. A lady drew my attention in the Midlands to a " beautiful old cottage." Beautiful it certainly was, with its framework of dark oaken beams among the white " roughcast," the red roses trailing over the lintel, the thatched roof-

The lovely cottage in the guardian nook,

With its own dear brook,

Its own pasture, almost its own sky.

But inside there was no place in the one small living room free from draughts, water trickled through the worn-out thatch, the floors were cold and damp. Upstairs were two small bedrooms, where slept a man and his wife, two sons and a grown-up daughter. A very small proportion indeed of village bedrooms contain a fireplace. Yet think what it means to nurse a case of, say, pneumonia, in an unwarmed bedroom. Far more attention is bestowed in some places on healthy accommodation for horses and dogs than on 
that required for the families of agricultural labourers.

The sanitary arrangements are often deplorable. In one case only three closets were provided for forty-four cottages. In another village I found the blood and other liquid refuse from a butcher's yard flowing in an open gutter within a foot of the cottage door, and the Rural Authority refused to interfere. Rheumatism and pleurisy are the natural outcome of damp walls and floors, and stuffy rooms provide a nidus for the germs of consumption, which sometimes infect an entire family in succession.

The whole theory of the vigorous health enjoyed by our villagers is undermined by stubborn facts of experience. The agricultural labourer often, it is true, lives beyond the normal span of life, but he rarely ends his days as a hale and hearty old man. Constant exposure to the cold and wet, his damp and draughty home, his poor fare, all combine against the labourer's constitution. Rheumatism in various forms is widely prevalent, and the stooping posture of the "Man with the Hoe" soon becomes stereotyped. Other diseases which more especially affect rural workmen are bronchitis, pneumonia and heart disease, and owing to disgracefully inadequate 


\section{PROBLEMS OF VILLAGE LIFE}

sanitation and the use of polluted water in surface wells typhoid is prevalent. Lunacy is increasing markedly among the rural population in some parts of the country. This is no doubt partly owing to the fact that emigration tends to eliminate the more vigorous in mind and body and leave behind the less healthy and efficient.

The trite belief in the healthiness of our village children is equally contradicted by experience. Statistics furnished by official enquiries in certain counties reveal the startling fact that from 60-70 per cent. of the children are more or less unfit, and the chief cause of their defective condition is admittedly malnutrition. Mr. Seebohm Rowntree's careful estimate of the minimum requirements for the physical efficiency of a family cannot be lightly brushed aside by the idle chatter of well-to-do persons about " chubby, well-dressed boys and girls."

Even of such cottages as exist-in too many cases uncomfortable and insanitary-we do not possess nearly enough for the needs of our rural population. Old cottages decay until they are abandoned, no more are built to take their place, and so in many parishes there is a positive dearth of dwelling-houses. Young men and women who would like to marry and 


\section{THE RURAL EXODUS}

settle down in their native villages are driven to migrate because no home is available. The Daily Mail of September 25, 1911, contained an account of a respectable Chelmsford labourer who had been driven to take shelter in the workhouse because he could find no house in his parish. The dearth of houses is very marked in Essex, and long engagements, sometimes extending to ten years, are often the necessary prelude to marriage. The whole social system of rural England seems to form indeed, unconsciously as it were and unintentionally, one vast conspiracy for expelling the people from the country. More pheasants are bred every year, more gamekeepers employed, more motor-cars bring down the week-end guests, while men and women drift citywards, in order to find a shelter for their heads.

There is another salient evil in our rural housing. More and more the cottages have become " tied" to the farms. Such dwellings. are occupied on the most precarious tenure, and if a man displeases his master he runs the grievous risk of losing not only his job but his home. A young man, honest, sober and industrious, came to me on one occasion in sore distress. He had, after tedious delays, secured a small holding in a Midland parish, 


\section{PROBLEMS OF VILLAGE LIFE}

but his cottage had been bought by another landlord, and was needed for the accommodation of a stranger who had secured employment on one of the landlord's farms. The small holder had spent long hours of overtime and a large portion of his slender capital on his five acres, and now he was deprived of his old home and quite unable to find any other in the parish. The chief landowner refused to build any more cottages, and my friend endeavoured to secure an old railway carriage as a dwelling-house on a corner of his holding, failing which, he would be compelled to surrender his bit of land and seek a living elsewheré.

The moral results of rural overcrowding have been alluded to elsewhere. Men and women leave the country because, in the absence of decent houses or any houses at all, they have, in the Duke of Marlborough's words, "nothing to stay for:" on the other hand those who elect to remain are compelled too often to live under conditions which are dangerous to their moral and physical health. "By a horrible paradox," says Mr. Chesterton, "there is overcrowding even where there are not enough people."

Legislative proposals have been put forward in the past, and will doubtless be put 
forward again, which would enable landowners to obtain grants of public money in order to build the necessary cottages on their estates. As long however as the existing conditions of our land system are allowed to continue, nothing can be clearer than the responsibility of those who possess the land of England to see that their dependants are decently housed. This duty cannot be lightly ignored by our country landowners, whose aggregrate rent amounts to some $£ 37,000,000$ a year for England and Wales alone. It may be perfectly true that cottages cannot be built to yield, say, more than a bare $2 \frac{1}{2}$ per cent. on the outlay, but we must not forget that the cottage rents are low simply because the wages are low. There is a tacitly understood bargain between employer and employed in the country parishes-"we pay you low wages and you shall have cottages at a low rent."

It would, however, be unjust to take for granted that all the "vile and deplorable dwellings " of the Housing Commissioners' Report are the property of big landowners. On the contrary, some of the worst of our rural cottages belong to persons in far humbler walks of life, whose scanty earnings are invested in this type of property, and who suffer acutely by the issue of official orders for extensive 


\section{PROBLEMS OF VILLAGE LIFE}

repairs or compulsory closing. In some unhappy cases a labourer has himself invested all his savings in the purchase of the tumble-down cottage in which his life has been largely spent. The problem of housing reform is sorely encumbered with the hard cases of the poor proprietor.

Such in brief are the admitted evils of rural housing. They have existed in our midst for years, and while the national wealth advances, and the prosperity of agriculture increases, this social blot still remains on the surface of our body politic. The evil gets worse if anything as the years roll on, for the supply of new houses does not keep pace with the disappearance of the old ones. "The English squire, the ruler of England," writes Mr. Chesterton, " has made the one great mistake of supposing that if you leave a thing alone it goes on as before. If you leave a thing alone it goes to the devil."

Side by side with economic causes, there are other reasons for the pitiful decline in our agricultural population. By painfully slow steps the proletariat of England is being educated, and from improved knowledge and decreased religion is born that eager cry for more pleasure, greater happiness. Cheap trips in over-crowded trains, the huge attend- 
ance at a Crystal Palace football match, musichalls filled to overflowing, are phenomena which may be laughed at or ignored by the well-to-do classes, but they are nevertheless full of social significance. They are the signs and tokens of a popular Hedonism, a new spirit in the people, half frivolous, half angry -a determination that places the joie de vivre amongst those monopolies of the rich and comfortable which must be broken down. Like all intellectual movements this demand for some greater share in the pleasures of life became insistent first in our towns, and has now reached the villages. Old men and women and young people of both sexes all alike cry out against the dullness of village life. The hours of labour are long; the distance from work, owing partly to the dearth of cottages, is often very great. Though it is customary to grant the better paid labourers on Scotch farms four days' holiday in the year without deduction of wages no such usage exists in England; and those who are charged with the care of animals usually work seven days a week. Even from " model villages," where wages may be high and houses excellent, the young people depart to seek in fresh scenes of urban or colonial life some greater opportunities for pleasure. The sarcasm of 


\section{PROBLEMS OF VILLAGE LIFE}

the late Lord Salisbury apropos of parish councils-"give them a circus"meaning to those who, like the writer, have spent long years in remote English villages. The experiences of my boyhood come back as a veritable nightmare-the dull scenery, the slush and mud of the roads, the absolutely mechanical existence of the villagers, who went to bed at eight o'clock to save oil and candles, the careworn faces of the women, the sullen endurance of their husbands, the dreary respectability of the farmers. And if this picture of village dullness imprinted itself on the mind of a boy living in comfort, the real significance of the scene for families living on $11 /$ a week can be imagined.

There is so little to refine the mind or cheer the soul in rural England. Music, for example, has largely disappeared from our villages. Puritanism proved too strong for such simple pleasures. In 1597 and 1648 minstrels were ordered to be branded, all ballad-singers were liable to be arrested, and all organs and lutes were to be destroyed. Cromwell's Third Parliament decreed the arrest of all musicians performing in taverns. And so it came to pass that even in the remoter parts of Great Britain, Wales, Lancashire and the west of Yorkshire, where the older traditions of 
Catholicism persisted, the folksongs and madrigals of the countryside have for the most part perished. Mr. Baring Gould and others have successfully preserved some of these local tunes and verses from Somersetshire and Devon, and I have heard quaint lines sung to unprinted melodies by old men in Oxfordshire, which, words and tune alike, are nigh unto vanishing away, for the young men and maidens refuse to learn the old songs, and when they sing at all use more or less obsolete music-hall ditties from the towns. The average concert in a country parish is an artificial affair arranged by the "residents" for the villagers, who accept the "good music" of their " betters" more or less gratefully.

There is a commonplace argument employed, and doubtless believed, by certain apologists for the existing conditions of rural life, that the poorer people are "sportsmen" at heart and staunch defenders of covert shooting and fox-hunting. Beaters are required for the wood, gateopeners for the hunt, barley for the horses, and what would village life be without the occasional " meet" on the green ? It is sad indeed that such an argument should be possible ; for to maintain that a miserablyhoused and ill-paid labourer derives keen satisfaction from seeing well-to-do residents 


\section{PROBLEMS OF VILLAGE LIFE}

and strangers collected on horseback and in motor cars and surrounded by all the embellishments of wealth connected with the most costly amusement in the world, is a contention of about the same validity as the wellknown one that the fox enjoys being chased and devoured. The joy of sport for those who can afford it is undeniable; few pleasures to the writer's mind can compare with those of shooting and fishing, but agricultural labourers and village tradesmen are learning to require something more solid than a vicarious satisfaction derived from the sight of other people's amusements. A fair proportion of British farmers are genuinely keen about field sports, and here and there you will find individual labourers standing up for the privileges of the "gentry," who occasionally require them as beaters. But I know of few sights more pathetic to those who long for better things in rural England than the group of extra men and boys sometimes collected for the beating of our coverts-the least efficient, the most hopeless of our poor folk.

Outdoor games do not naturally fall to the lot of men and boys who have no half-holidays, and not even a Bank holiday, nor, thanks to the force of Protestant tradition, much chance of using a portion of their Sundays for healthy 
recreation of this kind. In organizing village games, indoor or outdoor, I have always found two main obstacles: the men are too tired after their long hours of work ${ }^{\mathbf{1}}$ to indulge in further exercise, physical or mental, and they are usually too poor to pay even a small subscription with regularity. Cricket teams flourish in a fair number of our larger villages, but they are usually supported and "run," both as regards money and men, by well-to-do residents, and when matches are arranged, leave to take part must, in many cases, be secured either by the sacrifice of pay or by the indulgence of a kindly master. A striking feature of all outdoor sport and pastimes in the normal English village to-day is the lack of spontaneity amongst the poor themselves in the way of organized effort.

The same difficulty besets the organization of indoor amusements. It is, as a rule, far easier to initiate "reading-rooms" or " institutes" than to secure their continuance. The underpaid and tired labourers may be stirred into some show of interest and enthusiasm at first, but, without the constant stimulus

2 In the reign of Elizabeth the hours of an agricultural labourer were fixed at 12, with $2 \frac{1}{2}$ allowed off for rest and food, i.e., $9 \frac{1}{2}$ in all. The hours to.day are usually longer than they were three centuries ago! 
created by the well-to-do residents, the bare room, the tea and coffee, the more or less clerical atmosphere, the bagatelle board, the newspapers and magazines, the few volumes of "sound" fiction lose their charm, and are unavailing as a counter-attraction to the homely warmth and cheerful conviviality of the inn. In only a very small percentage of our villages is any kind of clublife possible apart from the public-house, and the diatribes of well-to-do and well-meaning members of city clubs against those who frequent the village inn are often strongly resented by even the steadiest and most sober labourers, whose sole opportunity for social good-fellowship is furnished by the bar parlour. Regret it as we may the fact remains that the one universal institution in rural England devoted to recreation is the publichouse. Some of the sterncr men avoid it altogether, though they possess no alternative resource. We have allowed a powerful and dangerous trade the virtual monopoly not only of rural drink-selling but of rural amusements; and a strange alliance exists between brewers and Temperance advocates to prevent even the trial in England of a system of public control and "counter-attractions" which has made Norway, once the most 
drunken, now the most sober, country in Europe. The crowd, the talk, the fun, the gossip which is provided every evening at a comparatively trifling cost-these things represent to the average labourer the one social institution which he can thoroughly understand and appreciate. If we could reproduce the image which in the labourer's mind sums up his notion of enjoyment, we should often find a picture of a narrow, halflighted room, cheerful companions round a bright fire, a sanded floor and the gleam of a pint of ale in a pewter mug. There is again the economic difficulty of running village clubs on the small subscription which the poor folk can afford to pay. I have myself had one disappointment after another with regard to such clubs. In poor and depressed counties like Suffolk, Berkshire, Dorsetshire and so on, the men and boys gradually cease to attend, they are fit for little except bed after their long hours of work, and the reading-room dies slowly of inanition. The poorly paid English labourer, the social product of long centuries of oppression and neglect, possesses neither the time, money nor enthusiasm for club life. The young men who still linger in the villages look forward to the moment of their departure or, at any rate, their abandon- 


\section{PROBLEMS OF VILLAGE LIFE}

ment of field labour for the more lucrative work on railways or in mines. I well remember in a Yorkshire village the little group of young men who would frequently walk a couple of miles to watch the expresses dash through the small station in the darkness. The interchanging lights of green and red and the roar of the train appealed to them, and the luminous smoke of the disappearing engine seemed like a pillar of fire by night to guide these poor village boys in their coming exodus. How pathetic, too, is the presence of quite small children at political meetings. It is sometimes necessary to exclude children under fifteen on such occasions, for the simple reason that otherwise small boys and girls surge through the door the moment it is opened and fill all the best places. These urchins understand scarcely a word of the speeches, but there they sit for two hours, quiet and well-behaved, their round eyes fixed on the speaker, and their little hands ready to increase the volume of rustic applause. The unintelligible meeting in the sleepy hours is an event in their little grey lives for which they "sit up!" The appearance of a political or "gospel " van is a still bigger event for the more remote villages. The men and women collect in little groups almost out of earshot, then gradually, as the 
sunset darkens the green, and their timidity grows less, they close upon the van, while a swarm of children cluster round the wheels and shafts.

The economic difficulty of feeding an average family on the average wages of an agricultural labourer has already been mentioned. Nevertheless the legend persists amongst well-fed people that the country cottager has abundance of sound if plain nourishment. On the contrary, Mr. Seebohm Rowntree's estimate that adequate nutrition and maintenance could not be provided for a rural family of five for under $£ 10$ s. $6 \mathrm{~d}$. a week ${ }^{1}$ holds the field, and demonstrates quite clearly that the wages received by the vast majority of English agricultural labourers are insufficient to maintain their families in mental and physical efficiency. The outlay in any workhouse for the food alone of a family of five-and that purchased in large quantities at contract prices-would reach some $3 /-$ more than the average wages of a labourer in the south of England! A little arithmetic with the domestic possibilities of $13 /$ - to $15 /-$ a week is indeed a useful cor-

${ }^{2}$ Food 13s. 9d., Fuel 1s. 4d., Rent 2s., Clothing 2s. 3d. (6d. each adult, 5d. each child), Insurisice 4d., Sundries lod. 


\section{PROBLEMS OF VILLAGE LIFE}

rective to gencral statements that village labourers and their families manage to live well and healthily on their incomes.

Or will you praise the homely, healthy fare, Plenteous and plain, that happy peasants ahare ?

Oh! trifle not with wants you cannot feel

Nor mock the misery of a stinted meal.

The common feature of the labourer's diet is its depressing sameness and the absence once more of initiative and enterprise. ${ }^{1}$ We are struck by the meagre use made of vegetables, the almost complete absence of the cheap and savoury soups which Continental peasants prepare so deftly, the comparative rarity of the fish which bulks so largely in the dietary of our townsfolk. General criticism directed against the "thriftlessness" of our agricultural labourers' wives largely falls to the ground in face of the mere fact that the miserable wages "go round" at all, but when a foreigner denies that our poorer housewives know how to cook properly he is on surer ground. The English race appears to have little aptitude for clever cookery, and as long as the better-off classes arc content with chops

- For careful and accurate examples of an agricultural labourer's dietary collectod from various counties, soe Mr. Seebohm Rowntree's latest book, How the Labourer Lives. 
and steaks, and the poorer folk with bacon, bread-and-butter and tea, such articles will form staple features of our public and private catering. Even tea, a national beverage, is too often, in the homes of well-to-do and poor alike, a vile decoction, carelessly prepared and positively deleterious to health. We are told that County Council lectures on Cookery are badly attended, and that our village matrons obstinately refuse to learn fresh methods of cookery even when these produce cheaper and more savoury food. Inadequate grates, dear coal, and the care of small children are factors in the question which are frequently overlooked by well-to-do critics of cottage cookery, nevertheless one must admit that the excessive sale of tinned meats in country villages would suggest a certain amount of culinary ignorance and lack of initiative in the homes of the poor. When a young villager finds himself, as a bachelor, in a big city he can secure for a few pence good and savoury food which forms a signal contrast to the plain and monotonous diet of his country home.

In sharp contrast to the grinding poverty and dull monotony of the village, a vivid impression of urban comforts and pleasures is conveyed to the rustic mind by the visits from time to time of country folk who have migrated 


\section{PROBLEMS OF VILLAGE LIFE}

to the cities. The self-confidence, general smartness and superior clothes of the visitors form a powerful stimulus to the young men and women of the village to try their luck also in an area of better pay and bigger opportunities. Literature, art and social conventions unite in regarding the "yokel" as the " infima species" of citizenship, and few girls once emancipated from village life will return to marry and settle down in the parish of thcir childhood. Suppose again that a boy of eighteen has summoned up courage to enlist. In a year he returns on furlough in his smart tunic, with the startling information that in addition to good food and warm clothes he finds himself at the end of the week with five shillings or more in his pocket to be spent as he likes. These youthful soldiers are the best recruiting officers for our rural villages.

The inevitable replacement of human labour by the use of machinery has furnished another cause of the exodus from the country. The advance in agricultural machinery has been smazingly slow, for there is no striking evidence of inventive ability about a reaper or a drill, and even when such obvious contrivances were brought into being years elapsed before they were widely used. Hence 
the displacement of labour by machines was gradual, and its economic effects less heavily felt in agricultural than in some other great industries. In the Rural Report on the Poor Laws in 1817, it is stated that a considerable number of labourers have been thrown out of employment in consequence of the use of machines, but the Report of 1843 makes only one slight reference to the subject. It was in the three decades 18511881 that the economic pressure from the new machinery was most heavily felt, and we find that in the last ten years of this period the owners and operators of agricultural machinery had risen in number from 2,160 to 4,260. In the days of Joseph Arch's Union the opposition of the labourers to the introduction of new machinery appears again and again, and one of the weapons employed against the strikers was the proposal to limit the demand for labour by an additional use of machinery.

Another explanation for the disappearance of young men from the country is to be found in the unattractive character of the career open to a class of men underpaid, overworked, and for the most part absolutely cut off from any share in the land they help to cultivate. Young men in most other walks of life enjoy 


\section{PROBLEMS OF VILLAGE LIFE}

prospects of promotion and increased pay. The general prospect before the agricultural labourer is, as a rule, singularly cheerless. When a childhood of toil has been left behind and the adult farm-hand receives the full weekly wage, the economic high-water mark is reached, and the only alteration in his earnings will be an inevitable decrease when a wife and children fall to his lot and increasing age gradually lessens his value. The monotonous toil, the meagre returns, the hopeless outlook were easier to endure half a century ago. Until the last few years no less than 45 per cent. of our agricultural labourers were in their old age condemned either to outdoor "relief" or the virtual imprisonment of a workhouse. The passing of the Old-Age Pensions Acts, a beneficent measure appreciated far more in the villages than the towns, has doubtless saved many country-folk from the pauperism which would otherwise have proved their natural fate. The normal career of an agricultural labourer had hitherto been poverty and hard work from the cradle to old age, with pauperism in the evening of his days. But now a new spirit of hopefulness has reached the younger generation in our country parishes. Young women leave one "situation" after another 
in their reasonable desire to "better themselves." The "finery" and "smart clothes" criticised by mistresses are merely symptomatic of the same tendency towards fuller and more comfortable conditions of life. Young labourers in the vigour of early manhood ask themselves why they should serve a master all their lives for 15/- a week, living in a "tied cottage," and liable to a week's notice to quit. Many of these men would gladly remain if a small portion of the land around them could ultimately find its way into their hands. Without perhaps that passionate devotion to the soil so vividly portrayed in La Terre, the English villager nevertheless in most cases leaves his fields and hedgerows with regret and sometimes real sorrow. I have talked with young men who declared with tears in their eyes that if they could have secured even five acres of land they would have gladly remained in the village of their boyhood, but stay there as labourers at $13 /-$ a week they would not. The "land hunger" in rural England, although it seldom reaches the proportions indicated in the speeches of "single tax" enthusiasts, who seem to believe that every villager is clamouring for a small farm, is nevertheless a very real thing. Despite a long series of political deceptions and 


\section{PROBLEMS OF VILLAGE LIFE}

promises unfulfilled the labourers' interest is still aroused by the cry of the land in any Parliamentary contest. How well I remember the autumn of 1908, when I held fifty meetings in Oxfordshire to explain the Small Holdings Act in the belief that now at length "land for the labourer " meant something more than the cruel delays and feeble achievements of the Small Holdings Act. The village schoolrooms were filled with audiences as big as those which came together at the General Election, aid labourers, young and old alike, with their wives trudged through the dark and muddy lanes to hear of an Act which might help to make their lives better worth living.

This golden opportunity of real land reform has been lost, and the younger men are emigrating in hundreds, exchanging the elusive hopes of land in the country of their birth for the certainties of Canada or Australia. The returns of recent emigration are startling, and according to Mr. Chiozza Money's careful figures it would appear that this has almost passed the limits of healthy expansion and become a dangerous drain on our national resources at home. No less than 33,000 persons have left our ports for the Colonies during the year 1911, and complaints of scarce 
labour due to emigration pour in from even comparatively well paid counties like Kent. Returns from only 88 of Devon's 461 parishes show that in the past twelve months (1912-13) no less than 2,114 have emigrated to Canada, Australia and New Zealand. Most of the emigrants are young men. The young villager, conveyed by a " cheap trip" to London or some other big city, gazes upon the wonderful window-dressing of the Canadian and Australian Agencies. The sheaves of heavily eared wheat, the samples of fine fruit, the models of well-built homes and waving cornfields are all the visible signs of an independence and prosperity easily within the emigrant's reach, but beyond the extremest hopes of a man who stays at home.

There is one privilege denied to his forefathers which the labourer possesses-he can leave the land when he likes. And so it comes to pass that with or without an articulate excuse he turns his back on the village. He packs up his scanty goods, and silently, without consultation, without murmuring, he rises up and goes. And it is this which in the course of time will bring salvation to him and his class. The agricultural labourer is indispensable; the nation cannot prosper 


\section{PROBLEMS OF VILLAGE LIFE}

without him. And this the nation begins to recognize. Still but dimly aware either of its causes or its threatened results, Englishmen are beginning to regard with vague and undefined dread the peril of the Rural Exodus. 


\section{CHAPTER IV}

\section{RURAL EDUCATION}

ONE of the most depressing features in the rural life of England, as apart from that of Wales and Scotland, is the general unpopularity of education. The village heckler who demands of a parliamentary candidate whether he does not think that children should leave school earlier in order to help towards their upkeep is always sure of much sympathy from Liberals and Tories alike. It is not difficult to explain this dislike of elementary education on the part of so many parents. One reason is the absence of any general enthusiasm for education in England: "the last thing," says one of Bernard Shaw's characters, "that an Englishman likes to be called is intellectual." There are very few Robert Elsmeres amongst our landed gentry ; nor can you expect much enthusiasm for "book-learning" amongst the labouring population of our countrysides. From generation to generation the dependent poor have 


\section{PROBLEMS OF VILLAGE LIFE}

been provided with an absolute minimum of "education," or none at all.

It is indeed in many cases quite impossible to inspire in village parents any genuine appreciation of the benefits of education. Here once more we see the low wages of our labourers operating as a cause of social mischief. Their life-struggle is so keen and incessant that the inducement to secure an additional shilling from child employment is terribly strong. The poorer folk have not yet followed the example of the well-to-do in the matter of family limitation, and every new baby represents a prospective drain on the home resources for thirteen years. The practical value of a good education, visible enough in the crowded competition of the city, is far less evident to the eyes of rural parents who are often barely able to read and write themselves.

Here and there you find poor folk who dimly realize how the absence of "book-learning" has handicapped their own career and robbed them of any real chances of betterment. I have often heard old men and women describe pathetically enough their total lack of " schooling," and how even the love-letters of rustic youths and maidens were written from clumsy dictation at one end and deciphered at the other by the parson or schoolmaster ! 
We have made some progress since the "Forties," when public opinion actually allowed children of six to be employed on farms and so permanently debarred from any school attendance whatever. It was highly creditable to Joseph Arch and the other leaders of the great Strike that they succeeded in placing among the objects of the National Union a demand for free and compulsory education.

The farmers are almost solidly opposed to any extension of the school age, and many go so far as to distrust education altogether. Compulsory schooling is held by many to be responsible for restlessness and the willingness to listen to " agitators." Mr. Rider Haggard's conversations with farmers and land agents bring this point out very clearly : one of his informants boldly advocated the passing of an "Act to abolish education." "Over-education of the labourers' children," is a phrase constantly on the lips of rural employers. The theory which underlies the fulminations of these critics against the State's education of its young citizens seems to be this, that in the scheme of Providence provision is made for various class-creations, and that a certain number of rural children come into the world predestined to a wage of $15 /-$ a week by the 


\section{PROBLEMS OF VILLAGE LIFE}

Almighty, who is understood to be more or less in harmony and agreement with the squires, farmers, clergy and the other "quality" of the parish. It is the foreordained career of these rustic infants to stay in the village and work on the farms: the shades 'of their prison have closed round them from their birth : education is wasted on the "man with the hoe:" education and discontent go hand in hand.

This crude and selfish doctrine of overeducation is openly preached by persons who begin to send their own children to school at the age when the sons and daughters of the poor are leaving it for good! Well-to-do parents whose thoughts are centred on the advancement of their boys, who grasp the importance of a good education in this connection, who are constantly endeavouring to better their own position in life-these same people unite in wishing to deny the offspring of the poor any substantial improvement in their lot and regard laudable ambition in the parents as undesirable and dangerous.

Another demand is frequently made in the supposed interest of the rural population: it is alleged not so much that education itself is unnecessary or undesirable as that the existing type of school training is quite 


\section{RURAL EDUCATION}

unsuitable. This view has been ably maintained by that sincere friend of the poor villagers, Mr. Jesse Collings. He goes so far as to believe that "the direct tendency of the (present) education is to create a distaste for manual labour of all sorts-and a dissatisfaction with country life generally. By it new ideas, totally dissociated from the localities in which they live, are instilled in the minds of the young, who believe that such ideas can only be realized elsewhere."

Here again the argument rests on the assumption that the village child is predestined to live and die as a quasi-serf on low wages. Well-to-do parents may select careers for their children; not so the agricultural labourer. To make anything of him, the villager, like Dr. Johnson's Scotchman, must be caught young, and carefully instructed in "Fruit-, flower-, and vegetable-growing ; poultry and bee-keeping; budding, pruning and grafting ; cow and pig-keeping ; milking ; rotation of garden crops ; nature and choice of seeds; structure, life and food of plants; action of birds and insects on crops; use of manures; use of simple tools ; packing fruit, vegetables and other produce for market." 1

1 See Schedule to "Agricultural Education in Elementary Schools Bill," presented March 9, 1905. 


\section{PROBLEMS OF VILLAGE LIFE}

This wonderful compendium of botany, zoology and rural economy is to form the intellectual nourishment of the village child up to thirteen; for "children engaged in book-learning and literary mummery till they are thirteen or fourteen years old " cannot digest it. One can readily understand that if even a fair portion of this agricultural curriculum were mastered there would not be much room left for much "book-learning" of the normal type. "Literary mummery" indeed! What does the normal education of our village children actually amount to ?

Here is the time-table of a thoroughly good village school in the Midlands, which may be taken as typical of the normal curriculum provided in a country parish.

hrs. mins.

Arithmetic $\quad . . \quad \ldots 340$ a week

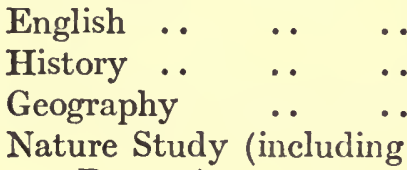

Botany) .. $\quad$.. 200 ,

Drawing _. $\quad \ldots \quad 2 \quad 20$,

Hygiene . . .. $\quad$. 0030 ,

Gardening $\quad \ldots \quad \ldots \quad 2 \quad 0 \quad$,

Singing (both notations) 130 ,

Repetition .. $\quad$. 110 , 
In addition to these subjects there are hours devoted to reading, writing, spelling, religious instruction, etc.

What more can one reasonably expect to be crowded into five days a week ? If you largely increase the hours allotted to gardening or Nature Study in the above time-table, the length of lessons in Arithmetic, English, History and Geography-none too long at present-must be cut down. If the various subjects of Mr. Collings' Bill be included in the day's work, the "literary" tuition must sink to vanishing point!

Even these beggarly elements of the village school-primitia juvenis misera-are to be jeopardised or diminished in order to secure a specialised instruction which will produce a skilled and intelligent workman on 15/- a week! Fancy the educational ideals of people who advocate such "specialization" as this ! A principle which would be acknowledged as absolutely vicious for the children of the rich, before say, sixteen, is warmly advocated for the children of the poor at five! To abandon the little we have secured for our people in the way of general education-in order merely to render our children more effective labourers -would be a retrograde step unworthy of a civilized community. These cries of the " over- 


\section{PROBLEMS OF VILLAGE LIFE}

education of the masses," and the inferiority of " literary" to " technical " instruction, though advocated sometimes by persons of absolute sincerity and goodwill, are really based on class selfishness of the worst kind. The spirit which underlies such proposals is akin to that which preaches the need of temperance laws for the Rand Kaffirs in order to secure their regular attendance at work. The child who has been reared on an "agricultural education "tends to become astrictus gleboe, and from the necessary absence of more general instruction a contented and dependent parishioncr.

But while the practical displacement of the present primary education - for that is what is involved in the adoption of such a scheme as Mr. Jesse Collings'-cannot be justified, no reasonable person could object to the adoption in our country schools of lessons in gardening, agricultural chemistry and the like : and as a matter of fact simple and useful instruction of this type is very frequently found in our rural districts, more especially where a small plot of land can be secured in the neighbourhood of the school. Claydon in Buckinghamshire is an example of what can be accomplished in this direction by a village school, and my old friend, Mr. W. H. Piggott, 
the well-known schoolmaster of Bicester, regularly led off his pupils to a neighbouring allotment for lessons in elementary horticulture. The knowledge of arithmetic is also an asset of great practical value in the country. Old labourers constantly tell you how in days of old when they did piecework at so much an acre, their employer frequently took advantage of their ignorance to underpay them. Simple book-keeping, again, is of the greatest possible utility to a small holder.

The hostile critics of our present system frequently point to the meagre results secured by our primary education as an argument in favour of substituting more practical instruction. We are reminded of the fact that many young labourers and servant girls of twenty-five can just manage to spell out a newspaper paragraph or scrawl a mis-spelt letter. But even if this be the case-and the number of our illiterate voters decreases year by year-there is nothing very surprising about it. How much Latin or Greek is remembered at the age of forty by the University pass-man who began his school life, instead of ending it, at thirteen and continued his studies of these languages till twenty-one ? "This glib talk of over-educating the rural children," writes my friend, Mr. Warren, a 


\section{PROBLEMS OF VILLAGE LIFE}

well-known Oxfordshire schoolmaster, " comes largely from ignorant or biassed people. The education we give is not too much: on the contrary it is too little. But there is one great drawback and that is a limit of time. Sad to say, many parents in the rural districts are so situated that every shilling is of importance to them, and, in consequence, the moment their children can be legally removed they take them from school: and what makes it sadder still they leave their studies for ever. The whole expense of education in such cases is sometimes almost a dead loss. There should be compulsory continuation schools until a certain standard of education is reached."

Whatever criticism may be passed on our educational system, the schoolmasters and mistresses of our rural schools form a class of which the community may well be proud. Nevertheless the unfortunate absence amongst the English of any real enthusiasm for education has hitherto prevented us from doing anything like full justice to the men and women to whom is confided the momentous responsibility of training our young citizens. A village schoolmaster is often worse paid than an artisan, and until recently no provision existed for the payment of long-service pensions. His social position in a country village 
is often rendered ambiguous and uncomfortable. He is frequently the best educated man in the parish and yet wholly cut off from the society of intellectual equals. The very unapostolic tradition that clerical families must be, in an especial sense, "gentlefolk" usually prevents any real intimacy between the School House and the Vicarage; on the other hand, while the farmers and tradesmen are ready to extend the hand of fellowship, these honest and kindly neighbours never possessed either the time or the money to equip themselves with a mental training like that of the schoolmaster. And so it comes to pass that the master or mistress is almost always to some extent an isolated being. Yet despite all such drawbacks these zealous servants of the State, generally underpaid and often unappreciated, not only carry on their normal employment, but frequently add to it voluntary works of supererogation in the way of night schools and other forms of extra tuition. 


\section{CHAPTER V}

\section{VILLAGE POLITICS}

THE political existence of our country villages in any real sense began in 1884. Before the extension of the franchise in this year rural England had been represented by the votes of a well-to-do minority of the inhabitants and the suffrages of the non-resident plural voter. The grant of the franchise to the labourer appeared likely at first sight to produce a complete change in the character of rural representation in Parliament. The writer remembers quite well the gloomy prophecies uttered by his father, the strongly Tory Rector of a Suffolk parish, to the effect that never again would the agricultural counties return a Conservative to Westminster. Such fears have been completely falsified, and to-day the poorest counties of southern and midland England form a political stronghold of the Conservative party.

There are various reasons for this fidelity to Tory principles in rural districts. The 
countryman, if unaffected by any special inducements or menaces, tends naturally to pursue the even tenour of his way in political as well as social life. The whole history of his harried and neglected class has produced in his temperament a vein of caution and suspicion and a mistrust of changes proposed by his "betters."

Even amongst his own neighbours the labourer preserves the same attitude of cautious reserve. One of the minor difficulties experienced in the administration of the Small Holdings Act was caused by the labourers' unwillingness even under the seal of official silence to declare the amount of their savings and resources. Before the advent of the railway and the bicycle ${ }^{1}$ our English villages, in the remoter districts, formed tiny communities,

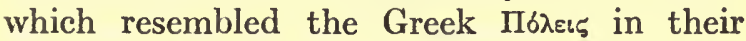
mutual mistrust and aloofness. Such village antagonisms are still met with here and there in the country, based on nothing else save the exclusive traditions of earlier centuries. The natural corollary of such a mental attitude is Conservatism, and side by side with this

1 A friend of mine on a recent visit to William Morris's hamlet of Kelmscott was greatly impressed by the immense improvement in the outlook and attitude of the younger men, which he attributed very largely to the civilizing use of bicycles. 


\section{PROBLEMS OF VILLAGE LIFE}

is the fact that, as a general rule, the Tory candidate is a man who lives in the county. On the other hand a large proportion of the Liberals who seek the suffrages of the rural parishes are more or less strangers, and in many cases chosen with more apparent regard to the fact that they can pay their own expenses than that they are either resident in the county or acquainted with its needs and conditions. Local and personal sentiment are not extinct even in men and women who spend their lives in the depressing depths of rural poverty, and many of our rural electors consistently follow the lead of the squire at election times, even when-as is not always the case-they believe in the absolute secrecy of the ballot. "The labourers' patient toil," says Mr. Phillips in the English Review, " in itself unrewarded, is consummated in the free step and gallant bearing of the squire, who rides as straight as he shoots, and has a neighbour's sympathy for all that grows in the country." The force of these personal ties is diminishing year by year. Not only is the growth of independence inevitable from the gradual spread of education and fuller contact with the cities, but a new type of landlord has appeared within the last fifty years. The feudal loyalty which constrained a village to 
acquiesce in the political lead of a landowner, however stupid and selfish he might be, ceases to be operative when the old-time owners of the soil are replaced by wealthy merchants and stockbrokers. The coveted title of "squire" may be secured by a person who runs an estate on the proceeds of beer or umbrella frames, but the glory has departed from the word in the minds of the rustics whose rural lineage is not, like his own, superficial and make-believe.

The possession of greater wealth is another important asset of rural Conservatism. In some parts of the country a candidate who is poor suffers in comparison with his opponent, not merely because he is less likely to subscribe liberally to local funds, but simply by reason of his comparative poverty. I have known it thrown in the teeth of a candidate by labourers living on $12 /-$ to $13 /-$ a week that he rode to the meeting on a bicycle (in contrast to his opponent's motor-car). Another hard-working candidate was assailed by the cry that he was "too poor to marry and lived in a small house." In an eastern county a labourer remarked to a young, cultivated, well-born politician of very limited means who had given him a tip, "Lor,' sir, you ought to have been a gentleman." 


\section{PROBLEMS OF VILLAGE LIFE}

No Liberal can be thoroughly satisfied with the conditions of rural England at present, and it is equally clear that large tracts of rural England are not satisfied with Liberalism. Bedfordshire, Cambridgeshire, Cornwall, Devon, Leicestcr, and Norfolk are the only counties where Liberalism is predominant. Not a single Liberal is returned in any division of Berkshire, Hampshire, Herefordshire, Hertfordshire, Huntingdon, Kent, Surrey, Sussex or Westmorland. Many obvious explanations are offered for this persistent refusal on the part of so many country constituencies to yield their wholeheartcd support to the cause of Liberalism. Social influences are at work in rural parishes which are altogether foreign to our urban life. Persons are permitted to exercise a control over the thoughts and actions of the "lower orders" whose political efforts would be quite futile in any industrial centre. The control of village charities, the practical monopoly, in some cases, of the house supply, the degrading patronage too often associated with private charity, the light of which is duly suffered to shine in the local newspapers - all these factors tell against the fortunes of rural Liberalism. There are hundreds of villages where a Liberal canvasser is told " they are better left alone; there are some Liberals 
there, but they don't like a Liberal canvasser to be seen on the doorstep." A lady canvasser in Oxfordshire was informed " Oh, it's no good your coming here, Miss, Mrs. K. (the Tory Lady of the Manor) arranges our politics for us."

But real and indubitable as the social pressure is, something more is needed to explain the comparative failure of Liberalism in country parishes; nor is this additional explanation far to seek. First of all, the principles and facts of Liberalism are not adequately taught in our villages ; and secondly, Liberal Governments have from time to time produced a large measure of irritation and angry disappointment in the ranks of their avowed supporters.

Most of the "quality," the "nobs" who employ labour, the representatives of " education," the clergymen who have been to " college," in many cases the schoolmaster-all these important persons quite naturally decry Liberalism in general and Liberal candidates in particular. And over vast areas of rural England the villagers are unprovided with any kind of Radical newspaper. The country Press is very largely Tory, and the weekly newspaper, the one literary luxury of the labourer, the single journal that he and his 


\section{PROBLEMS OF VILLAGE LIFE}

wife ever read, is in most cases strongly Conservative. What would have been the mental history of, say, the members of the Reform Club, if during the whole of their lives their sole political pabulum had been derived from the Daily Telegraph or the Observer?

On the other hand, there has been a tendency to overlook the agricultural districts when Liberalism secures a Parliamentary majority. What single measure, except the Old-Age Pensions Act, can be pointed to as having within recent memory stirred the enthusiasm of our English villagers, or impressed them with any deep-rooted belief that politicians were working for their welfare, and prepared to defend the cause of the most helpless and most neglected toilers in the realm? Home Rule, Welsh Disestablishment, Redistribution, Parish and District Councils, Education Bills and the like have left men and women cold, who were struggling to keep the household together on 13/- a week. Temperance Reform has too often presented itself in the light of a "Local Veto," which would permit 200 persons in a country parish to absolutely cut off the remaining 100 from their one and only centre of social intercourse and good-fellowship, the village inn. The country electors have never made excessive demands. They 
have never clamoured for any political panem et circenses impossible or difficult to provide. All they asked for in 1906 was old-age pensions and access to the land at a reasonable rent. The first of the boons has come to stay, a measure magnificent in the humanity of its purpose and absolutely unique in the records of modern legislation. Had the land policy of the Liberal Party kept pace with Mr. Lloyd George's great measure, the adherence of the rural labourer-even allowing for that unpleasant factor, political ingratitude-might have been more firmly secured.

The Labour Party has hitherto made no impression on the rural constituencies. Its leaders are essentially urban in knowledge and experience, and amid the crowded problems of city life no room is found for any concentration on the needs of the village. In theory, of course, Labour politicians recognize that the influx of labourers from the country tends to diminish wages in the towns, and their sympathies have always been extended towards such palliative measures as have been framed from time to time for the benefit of the farmlabourer. After the middle of the nineteenth century a marked decline took place in the wages of the riverside labourers on the Thames; this was due to the inrush of Irish peasants. 


\section{PROBLEMS OF VILLAGE LIFE}

evicted from their farms after the famine, and the same economic process is still going on. Occasionally, the Labour Party have sent down one of their Members of Parliament into an agricultural district, but the experiment has not been attended with much success. Mr. Pointer, M.P., arrived at Bicester, in Oxfordshire, some three years ago, in the very centre of an agricultural district, but his excellent speech was rendered inaudible by every form of uproar, which ultimately took the form of open violence. Undeterred by this failure, Mr. Pointer tried again: but again the effort ended in a complete fiasco. Socialism is not yet understood in our villages either by rich or poor, and the leaders of the Labour Party have at present no time, amid the calls of the industrial centres, to extend their missionary work in thinly populated rural areas. The ordinary leaders of village politics, Liberal or Tory, have not got far in their conception of the Socialist creed beyond Punch's definition of it as "Atheism, free love and death to King George V."

The labourer of the villages is essentially, though well worth knowing, a hard man to know. Long centuries of oppression and neglect have left their mark on him, and unless one has time and patience it is difficult to 
pierce the atmosphere of quiet reserve with which the villager surrounds himself. $\mathrm{He}$ is rarely discourteous, and those who persevere in their efforts to gain the friendship of the cottagers are well rewarded. Some of the best and happiest hours in the writer's life have been spent in the humble dwellings of the village poor. How often have I shared in the kind hospitality of a cottage-the hot cup of tea, the bread cut thin for my benefit, spread sometimes with butter, sometimes with the cheaper lard. My heart goes out to these kindly friends-"si braves, si patients, mais il n'y a pas de l'argent" - as a Turkish officer once said to me when pointing to his gallant infantry. Nevertheless even those who have been privileged to share the intimate friendship of the village poor are quite unable sometimes to determine that treasured secret, the "way they vote." I know a late member of Parliament who quite despaired of the politics of a certain village. So convinced was he that the people in it were hostile to his opinions that he rarely visited it. Nevertheless, when a subscription list was started on his behalf among the many hundreds of signatures appended to it he saw the names of practically every labourer in the suspected hamlet. 


\section{PROBLEMS OF VILLAGE LIFE}

Born only to endure,

The patient passive poor

Seem useful chiefly by their multitude ;

For they are men who keep

Their lives secret and deep;

Alas, the poor are seldom understood.

To a very large extent then the English labourer has been disappointed and disillusioned in his political hopes. Before the bestowal of the franchise politicians devoted practically no attention whatever to the inarticulate villages, and since the vote was secured the help offered by members and candidates has been largely lip-service. The landlord and property influences in both the historic parties, and still more so amongst the permanent officials of Government Boards, have frequently succeeded in neutralizing the efficacy of reforms ostensibly directed towards opening the land to the poor and providing them with decent cottages. From decade to decade the villagers have been duped by cries like "Every labourer his own landlord" or the "Colonization of England."

The general interest shown in the local government of the parish and county is, as a rule, lamentably small. By a strange paradox the advent of local government has stereotyped the hopeless dependence of the labourer more fully than before. What part or lot 
has the cottager in the County Council, upon which, through the ingenious provision of refusing travelling and out-of-pocket expenses, it is practically impossible for a small farmer, village tradesman or labourer to sit? Doctrinaire politicians may point as they like to the fact that the County Councils are elected bodies; they overlook the fact that these rural parliaments are elected under social conditions which rigidly limit the choice of the voters, and in many cases secure the return of an illiberal and unprogressive majority. To take a single example, can any worse dereliction of public duty be adduced than the treatment accorded by the County Councils of England to the Small Holdings Act of 1892-a policy of utter neglect condemned by nobody more severely than Mr. Jesse Collings ? If a tenant-farmer ventures to stand for a County Council in opposition to a landlord it is frequently regarded in the district as almost a case of lése majesté. The average labourer regards the election and the work of the County Council with apathy and indifference. If he has failed to secure a small holding after four years' weary waiting as an " approved candidate," he is told by one set of comforters that he should see that Liberals are returned to the 


\section{PROBLEMS OF VILLAGE LIFE}

County Council; in most cases one might just as well urge him to take a trip to the Riviera.

The deliberations of the Rural District Councils are even more remote from the general life of the labouring classes. It is scarcely an exaggeration to describe them as " farmers' clubs," and the one central tradition of such bodies is-with rare exceptions-to keep the rates down and do as little as possible. Nevertheless to these Councils are accorded the administration of Acts of Parliament designed for the benefit of the labourers. Urban politicians, obsessed with the ideal of selfgovernment, propose to intrust far-reaching proposals for better housing to Councils whose record in many instances may fairly be described as one of obstinate obstruction and callous neglect. ${ }^{1}$ They fail to see that the habits of self-government-once so vigorously developed in the English village-have been almost atrophied for want of use during centuries of poverty and oppression. The Parish Council is the only governing body in which the labourers can play a part. Here

1 The Select Committee of the House of Commons appointed to consider Mr. Mackarness' Housing Bill in 1906 reported as follows: "It is clear that most Rural District Councils have taken practically no advantage of the Act (of 1890)."2 
and there the experience afforded by the work of these Councils-particularly that connected with the supply of allotments-has added interest to the life of the village and contributed to self-reliance and self-respect. But their powers are too insignificant to draw out real talent, to make it an object of ambition to become a member, or to invest the elections with the necessary atmosphere of popular interest and enthusiasm. 


\section{CHAP'TER VI}

\section{RELIGION OF THE VILLAGE}

Reuigious faith has always died hard in the village. Long after the constructive and destructive energies of the Church had triumphed in the cities of the Roman Empire, the poor pagani, or "villagers," preserved the dying embers of the ancient faith. Even in the twentieth century the former deities of the corn crop and vintage are still invoked in Christian Tuscany, while the traveller in the Pyrenees may still hear the call of "Iacche, Iacche," as the peasants winnow the corn with the mystica vannus of the old-time god. The mist of obscurity which settled on the religious conditions of the English village immediately after the Reformation has never been, as yet, completely lifted : but enough is known to make it clear that the change in the theory and practice of the people's religion was extremely gradual in many of the more remote parishes. 


\section{RELIGION OF THE VILLAGE 121}

There are therefore strong $a$ priori reasons why the religious life of our villages should flourish and abound. Nevertheless, few indeed are there of those who have lived in the country parishes, few even of those who have ministered in the Churches and Chapels, who will not deplore the decadence of religious faith and practice in rural England.

Here and there are men and women of deep piety, men and women whose first religious impulse has come in most cases from the camp meeting of the revivalist. These are the successors of the early Methodists, who gathered in their thousands on the open hillsides to drink in the gospel teachings of John Wesley. Theirs is a religion which, narrow and harsh in some respects, is yet an illumination. Their vision has transcended the outward things of the moment, and embraced the war of good and evil, the infinite mysteries of $\sin$ and its redemption. These men and women, however, are the exeeption. The normal religious life of the rural world flows in the two deeply cut channels of Church and Chapel, channels whose courses have not altered fundamentally since they were first determined by the great controversies of the seventeenth century. The division between these is not confined to the sphere of religion ; 


\section{PROBLEMS OF VILLAGE LIFE}

it extends to those of politics and even of ethics. It is difficult to decide which phase of religious activity exhibits the more vigorous life. In East Anglia and the south-western counties Nonconformity is the stronger; but Anglicanism is full of vigour in Lancashire, while in Yorkshire there are valleys which have scarcely heard of the Reformation.

The actual attendance at Church and Chapel services varies greatly in different localities. It has been stated on good authority. that not more than 25 per cent. of London's millions ever enter a place of worship. No such religious census has ever been taken over any large area of rural England, but in Oxfordshire, a purely agricultural county, free from the unsettling influences of large cities, I have attempted to discover the normal number of Sunday attendances at Church and Chapel, and find these amount to between 25-35 per cent. of the adult population. In proportion to the number of its professed adherents, Nonconformity appears to draw somewhat larger congregations. ${ }^{1}$

1 Absence from Church or Chapel is often due to a deeply rooted reluctance to appear in shabby or "odd " clothes. In many rural parishes new clothes are practically un. known. Second, third, and even fourth-hand suits 
The farmers and well-to-do residents generally tend to be Churchpeople and regard their presence in the Sunday congregation as "setting an example" to the poorer villagers ; there are certainly worse motives than this for going to Church.

It is a commonplace of contemporary criticism that in our urban centres the ancient sanctions of religion are rapidly tending to lose their efficacy. But in the air of the country the flowers of faith fade more slowly. Amid the unfailing regularity of haytime and harvest, and the close connection between natural phenomena and one's daily livelihood, Love and Nature seem less at strife. The even tenour of the rustic life is secure from the perils and vicissitudes of the city, and fewer appalling catastrophes occur to shock religious confidence. The Harvest Festival, with its semi-pagan offerings, forms an annual reminder of man's dependence on the Creator which has infinitely more significance to those who till the soil than to the townspeople who find their fruit and vegetables on costermongers' barrows.

and dresses from the towns are bought in the villages. These are sometimes patched or ill-fitting, and the countryman feels keenly the sting of ridicule on this score-

Nil habet infelix paupertas durius in se

Quam quod ridiculos homines facit. 


\section{PROBLEMS OF VILLAGE LIFE}

Further, the clergyman is usually a far greater personage in the eyes of rural than of urban parishioners. He comes from "college," dines occasionally with the squire, and, however free personally from pride or snobbery, is always regarded as belonging to a different class from the vast majority of his flock.

The vitalising influence of the Oxford Movement, though chiefly felt in the towns, left its mark also on our rural parishes. The improved discipline of the Anglican Church, while stili a somewhat feeble instrument, has at least helped to weed out many notorious cases of worthless clergymen and that spiritual caricature the "sporting parson," while infinitely greater care is exercised in Church patronage than was the case fifty years ago. Services are brighter and more numerous, and the connection between the Church and the social and intellectual life of the parish becomes daily more close. A general survey, however, leaves the impression that religion in rural England is more alive in the Nonconformist chapel than in the Established church. The emotionalism of the services, the popular phraseology, the vigour of the preaching, the sympathy between the members of each little congregation-all these things are strong influences; while the note of individualism in 


\section{RELIGION OF THE VILLAGE 125}

Nonconformist doctrine finds an answering chord in the rustic mind. The plainly built little chapels which everywhere meet the eye in our country parishes are outward and visible tokens of the splendid spirit of independence and self-sacrifice which animates the "Free Churches." Many of these buildings are paid for out of the depths of rural poverty. I have myself frequently spoken in a village chapel,

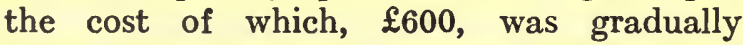
gathered together by the unceasing effort and amazing generosity of people whose average income did not exceed $£ 1$ per week. The congregations know that the weekly ministrations have to be provided at their own cost, and would lapse if their efforts were relaxed. The same spirit animates the detached communities of Roman Catholics, who, like their Nonconformist brethren, without ancient endowments or rich congregations, succeed in maintaining their services and their clergy in a manner which puts to shame the wealthier laity of the Established Church.

Nevertheless, signs of failure are only too evident in the work of all organized religion in our country districts. There is, it is true, very little of the anti-religious spirit which characterizes so large a proportion of the Continental peasantry. There is little, if any, 


\section{PROBLEMS OF VILLAGE LIFE}

active hostility towards Church or Chapel. Nor, again, is any public approval accorded to crude and abusive denunciations of religion. The speakers who in Hyde Park hold up religious faith in general, and Roman Catholicism in particular, to contumely or ridicule would not be appreciated in the average village. The prevailing attitude of mind would appear to be one of sheer indifference tinged less often with bitterness than with a kindly toleration. The force of tradition prevails even where religious sympathies have disappeared. "I want the little devils to be taught something about God" was the criticism passed on certain proposals in the Education Bill of 1908 by a labourer who never said a prayer or entered a place of worship, and even lifelong Nonconformists will have their children christened, their youths and maidens married and their dead buried in accordance with the -ancient rites of their forefathers' Church.

The ancient joys of rural life have vanished, crushed out by Puritanism and poverty, and free education and the newspaper have shown the villagers how unhappy they are. The face of a loving Deity is obscured by the mists which have settled on lives of ceaseless toil and miserable penury. One old man I knew used to sit beside the tiny fireplace in his 


\section{RELIGION OF THE VILLAGE 127}

cottage, his limbs twisted and gnarled by rheumatism-a worn-out toiler who had brought up a large family to the best of his ability; and often as he sat there gazing into the feeble embers, a tear would roll down his cheek, and he would exclaim, half to himself, "I wonder what it all means." Neither the parson's sermons nor the vigorous hymns of the Methodist chapel could satisfy the bewildered mind of this village agnostic, and so he and two-thirds of his neighbours stayed at home, communing it may be with their own simple souls and "wondering - what it all meant."

How then can we best explain the comparatively feeble growth of religious faith in a soil so well adapted for its welfare? The Established Church fails largely because its clergy are chosen from the "classes." It was one of Mr." Gladstone's least wise utterances that the Establishment provided us with the blessing of at any rate one gentleman in every parish. Gentleman indeed! This standard of "gentility" has formed one of the main obstacles to the spiritual efficiency of the Anglican Church. The general atmosphere of many country rectories is one of paupertas ambitiosa - the hat-touchings and curtseyings, the wagonette driven by the gardener in 


\section{PROBLEMS OF VILLAGE LIFE}

livery, the girls to have new frocks for the county ball, the sons to be "educated as gentlemen." Contrast with all this the social equality, personal affection and real respect which often mark the relations between a French curé, with 1000 francs per annum, and his parishioners.

Again the phrase "inferior clergy," once indiscreetly used of the rural parsons by a Church dignitary, has a meaning. The ablest and most zealous young men naturally desire to find their life-work in the environment of the big towns and the big opportunities offered therein. It is abundantly clear from the current experience of any Oxford or Cambridge " don " that the abler men at the Universities do not as a rule take Holy Orders, and that of the undergraduates who do become clergymen, the least efficient tend to occupy the country livings.

Further-and this is the strongest reason for the widespread unpopularity of the rural clergy and the neglect of the Church's ministrations-the clergy have always identified themselves with one political party-the party which, more especially in rural districts, stands for the defence of property, privileges and social influence. Mr. Masterman's dictum that no established Church had ever been 


\section{RELIGION OF THE VILLAGE 129}

on the side of the poor is supported by ample testimony from our country parishes.

The clergy, with rare and noble exceptions, like Bishop Latimer and Bernard Gilpin, threw in their lot with the wealthy and powerful men who through the Enclosures period gradually robbed the peasants of their land. In earlier centuries, while the poor farmers and serfs were outraged, pillaged, branded, slaughtered by foreign mercenaries, hung in batches from steeples and gallows and atrociously mutilated, the Church of Christ looked on, almost in silence. When hundreds of men and boys were banished for ever from England under the cruel sentences of the "Swing Riots" period the cathedral clergy at Winchester refused to sign the great petition for a merciful mitigation of these inhuman penalties. The traditional memories of this cruel past dimly persist in our villages of to-day, and were exemplified afresh when Joscph Arch did his best to instil some measure of hope in the breasts of the labourers. This whole-hearted reformer succeeded in raising wages by $2 /-\mathrm{a}$ week, but he accomplished this in the tecth of bitter opposition, not only from farmers and landlords, but from the parochial clergy ! Later on measures like the Small Holdings Act, the Old-Age Pensions Act, the Insurance Act 


\section{PROBLEMS OF VILLAGE LIFE}

have, alas, been received by the vast majority of the rural clergy with either open hostility or sullen acquiescence.

How well I remember the case of one Robert Clarke, a labourer in a remote Suffolk village. This man-a clever andindustrious workmanhad led a local strike in Arch's days, which had been defeated by the importation of Irishmen. For this offence he had never been forgiven. $\mathrm{He}$ was refused regular employment by the farmers, ignored by the parson, and universally described by the "residents" of the village as a "dangerous man." As a boy I used to pay stealthy visits to this Clarke, who lived alone in a tumbledown cottage, a broken man, full of helpless resentment. He had striven for some little advance beyond the miserable pittance of $10 /-$ a week, and for this crime he was treated like a social leper. Our villages in the southern half of England are full of these humble tragedies. Another honest man, $\mathrm{P} \longrightarrow$, in a Midland village, guilty of a similar offence to Clarke's, was refused all employment on farms or even road-mending. He then tried to make some sort of living by hawking fish, but bitter persecution pursued him, and when he failed and gave up the struggle and died, the village doctor exclaimed to a friend of mine, "Well, they've 


\section{RELIGION OF THE VILLAGE 181}

killed P_ at last!" No clergyman denounced the wicked treatment of this man : his own parson was popularly known as the "Devil of W_- "because of his savage treatment of poor-law applicants. But the case is still recorded in the neighbouring villages and serves, like the painful stories of other poor "village Hampdens," to alienate the English labourers from the Church of their ancestors.

The rural clergy are usually generous and kindly men, who subscribe to "charity" a proportion of their small incomes which would produce startling results were it applied as a rule to lay offerings. Nevertheless, they have in this matter thoroughly confused the issues. It is not personal charity which the neglected labourer primarily requires, but social justice. The clergy are ready enough to give alms, but they do not challenge the vicious system of inadequate wages eked out by charity. "The mistake of the best men," says Ruskin, "through generation after generation, has been the great one of thinking to help the poor by almsgiving and by preaching of patience and of hope and of every other means emollient or consolatory except the one thing which God orders for them, justice."

But the championship of such social justice would place the rural clergy in a "false 


\section{PROBLEMS OF VILLAGE LIFE}

position"; it would place them on the side of Radicals and "agitators"; it would lose them at one fell swoop the favour and support of patrons and churchwardens, and so they return to join the great army of kindly and well-to-do people, the recipients of whose bounty can never shake themselves clear of the mire of doles in which they wallow.

There is another explanation of the Church's failure. The evangelical Low Churchman is found less and less in rural parishes. The High Churchman - " moderate " or "advanced "reigns in his stead. The change has unquestionably been for the best as far as the Church's spiritual life and activity are concerned. Nevertheless, Anglicanism has never been really understood by the people generally or even by those who are specially attracted by the beauty of its services or the devotion of its priesthood. As far as the laity of the National Church are concerned the Catholic sense has been effectually stifled by the centuries of dull Protestantism which succeeded the "Great Pillage." The House of Commons is thoroughly Erastian. I doubt, from personal experience, if more than a score of members either understand or sympathise with the theory and practice of Churchmanship which inspires the bulk of our clergy. The Conserva- 


\section{RELIGION OF THE VILLAGE 133}

tive party are usually regarded as recognized supporters of the Establishment. But when grotesquely unjust Bills are brought forward to evict and imprison the clergy by hundreds, and replace the stone altar of Westminster Abbey by a wooden structure, the attack is led by the soi-disant champions of the Church and repelled largely by the assistance of fairminded Gallios and reverent agnostics on the Liberal and Labour benches. In our country parishes a High Churchman is rarely understood and frequently misrepresented. Many a parish priest recites his daily matins and evensong in an empty church. In other parishes you will find the large church a quarter full on Sunday morning while the rector walks up the aisle behind a gilt cross and five little boys in purple cassocks. There is real pathos in this failure to be intelligible on the part of the clergyman who from real conviction has striven to invest his services with a measure of beauty and diginity.

In summary then, we see that the Church of England is in a position, so far as outward circumstances are concerned, of infinitely greater influence than the Nonconformist bodies. It has a representative in every parish, charged with the care of every soul within its borders. Its ministers constitute 


\section{PROBLEMS OF VILLAGE LIFE}

one-fcurth of the resident landowners of England. It is supported by the richest classes in the community. It has inherited many a building which is not only a gem of architecture, but is marked by tradition and situation alike as the centre of the village. Its political influence is incalculable. Some of its clergy have used that influence-and there are those who are using it to-day-to promote the social as well as the religious welfare of their people, to form a right public opinion, and to hold up, against the suspicious individualism of country life, the ideal of fellowship in a great organization. And yet the Church remains out of touch with the spiritual needs of the labourer. Many of the clergy have earned his respect, but few his confidence. Few of them have taken his side in the questions which touch him most closely. To him they seem remote; a part of the world in which the landlord moves; prominent in the Conservative party; dwellers in large houses. $\mathrm{He}$ is glad, indeed, of the part they play at the critical moments-at the christening, the marriage, the burial ; it seems to him in the nature of things that they should be at hand to provide these offices. He thinks, too, that a certain amount of Church attendance, while it may do him some good, will certainly do 


\section{RELIGION OF THE VILLAGE 135}

him no harm. But this is not because the exquisite liturgies and ancient formularies adequately voice his reverence, his aspirations, or his fear. On the contrary, they are, to him, for the most part, incomprehensible. Nor does the service as a whole atone for this want of articulate expression. Lacking the social glow of the Chapel, yet shrinking from the powerful appeal of colour and movement and sacred symbolism, it leaves him cold.

Nonconformity, too, finds its difficulties in rural districts. It is true that the Free Churches no longer present themselves as the special enemies of social pleasures. In face of the age-spirit, clamouring more and more for happiness and pleasure, the ancient austerity of the Baptist and Methodist has to a large extent broken down. The younger generation of youthful Nonconformists discuss recent plays and take part in subscription dances. In one direction, however, modern Nonconformity maintains consistently the role of a crusade against popular sentiments, and that is in its splendid and uncompromising fight against the power of the Drink Traffic. The real weaknesses of rural Nonconformity arise from the financial power of an endowed and established Church in competition with its own meagre coffers, its inability to provide 


\section{PROBLEMS OF VILLAGE LIFE}

a resident minister in every considerable village, and, finally, the comparative failure of the pastoral functions of its ministers. For various reasons, good and bad, the Nonconformist minister does not "visit" the parishioners to the same extent as a vicar, who in virtue of his established position can in some cases demand and secure an entrée to the homes of Churchmen and Dissenters alike.

To what extent does the influence of religion guide the rustic moralist in life or cheer him in the hour of death? Such questions are hard to answer, but organized religion has failed so signally to support the toiling labourer in his struggles for betterment that the more positive and definite teachings of the Churches have lost the greater part of their efficacy in moulding the conduct of the English villagers. When a labourer complained that he had not been treated with "common Christianity," "Christianity!" said the farmer, "what has that to do with it? If you want Christianity there's the Church for you." The general acceptance of the doctrine of contentment and due subserviency to his "betters" has disappeared with the dame-school and the smock frock. The poverty and discomfort of the villages, to a large extent preventable, can no longer find their compensation in "blank 


\section{RELIGION OF THE VILLAGE 137}

cheques to be cashed on the other side of Jordan." The old villager is as a rule without any great desire to avoid the inevitable end. Life has never been very sweet, and so death loses half its bitterness : he is tired and willing to sleep. The mental indifference to eschatological possibilities which marked the closing scenes of Bettesworth, the Surrey labourer, is typical : dimly and dubiously he trusts the larger hope : he is neither scared into the paths. of virtue by the threats of punishment nor led thither by hopes of future recognition and happiness.

In the country districts of Ireland the Roman Catholic priests indubitably exercise a powerful influence over conduct, and rural Britain generally is free from crimes of outrage and violence. Economics and ethics are largely connected. The soberest counties of England, for example, like Oxfordshire and Wiltshire, are also the worst paid. Nevertheless no fairminded critic of our social life can avoid the conclusion that the standard of sexual morality is extraordinarily low in many parts of rural England. The Report of the Poor Law Commissioners for 1834 contains an appalling description of degradation, immorality and semi-barbarism produced by the rate-aided relief of the period : and there are 


\section{PROBLEMS OF VILLAGE LIFE}

villages in England to-day which are disfigured by some of the worst horrors of " $L a$ Terre." Nevertheless, for the stains on the life of our countryside, for the mental and moral foulness, due to the gang-systems of the past, to drink, to overcrowding, others than the actual offenders must bear a large share of responsibility before the judgment seat of Heaven. Those who monopolized the land, resisted education, set their faces like flint against Temperance Reform, and refused to build decent houses because they wanted bigger interest than $2 \frac{1}{2}$ per cent.-though kennels and stables are built at a loss-men and women who have talked of the rights of property and forgotten its duties, it is these who through the centuries have helped to put stumbling blocks in the way of the poor villagers and caused Christ's little ones to offend.

Here and there, it is true, we come across welcome signs of a change. A feeling is slowly gaining ground among Churchmen that the Church suffers from its almost exclusive connection with one political party and is humiliated by its alliance with wealthy brewers. In many parts of England the clergy must recognize that the people are alienated from the National Church by that 
obstinate opposition to reform with which the clergy and wealthier laymen have been associated. If an independent position were taken up, if the Church could be recognized as taking a line of its own on social questions, the hopes and affections of the people would gather round her in a way hitherto unknown. The part played by the priesthood in the agricultural revival of other countries, e.g., in Ireland, Belgium and Italy, is well known. Nevertheless it is doubtful if the great mass of clerical and lay Conservatives will be sensibly affected by the "forward policy" of the few. A Church prominently identified with the wellto-do classes cannot easily ally itself with a policy of reform, bitterly opposed by many of those on whose financial support it largely depends, and this difficulty will be rendered more pronounced when the inevitable disestablishment and disendowment of the Church of England comes to pass. Even within the narrow compass of parochial differences and disagreements complete independence is sometimes very difficult for an incumbent. The well-known case of Canon Girdlestone is typical, for a country clergyman who, in the event of a quarrel, sides with the labourers against the squire and the farmers, may find his position rendered almost unendurable. 


\section{PROBLEMS OF VILLAGE LIFE}

If the Anglican movement which has done so much to restore Church life in our towns and cities extends its influence more fully over the country parishes the best solution of Church difficulties in rural areas may ultimately be provided by brotherhoods of unmarried clergymen, working several parishes from a common centre. 


\section{CHAPTER VII}

\section{HOMES AND WAGES}

THE general conclusion drawn from a survey of the preceding pages or indeed almost any volume concerned with the subject must be that, on the whole, rural life in England is beset with many difficulties and disadvantages. The picture of the English village which has been drawn is on the whole a somewhat grey and depressing one, as indeed all pictures must be which portray the life of the great mass of the people instead of the pleasures enjoyed by a minute portion of them. Not only has chronic discontent come to be regarded as the peculiar attribute of English landlords, farmers and labourers, but every political party in the State acknowledges the existence of this rural characteristic and employs it as a basis upon which to build up schemes of reform. The Nationalization schemes of the Labour Party, the Protectionist policy of the Conservatives, the Small Holdings legislation of the Liberals -all alike take for granted the existence of 


\section{PROBLEMS OF VILLAGE LIFE}

rural evils and the justification offered for rural discontent. Scores of societies devote time and money to the attempted solution of rural problems, nor is this unselfish effort entirely confined to-day to one political party. One of the latest and sanest of these associations, the Land and Home Union, with a really "advanced " policy of rural reform, is presided over by a Conservative M.P., Lord Henry Cavendish-Bentinck, has a Fabian for its secretary, and Liberals on its executive.

The most fertile soil in the world is cultivated under social and economic conditions which are positive hindrances to efficiency. Vast tracts of land are devoted primarily to the encouragement of sport: methods of scientific agriculture, adopted in Europe with signal success, are with us tabooed from ignorance or prejudice : our supply of homegrown food cannot sustain the population for more than a few weeks. From time to time we have our writing on the wall. In 1911 and 1912 two national experiences fell to our lot, full of significance. A speech of the Foreign Secretary proved that we had recently been within measurable distance of war with a great naval Power; then came the coal strike which, while its full force was broken by forethought on the one side and mismanage- 
ment on the other, nevertheless-with all our imports unimpeded-menaced thousands of our poorer fellow-countrymen with semistarvation. If a disturbance of our internal communications could produce results so painful and disastrous, we may well stand aghast at the possibilities inherent in any serious naval interference with the importation of our normal food supplies. Few serious students of rural life can avoid the conclusion that all is not well with the land of England. Some will maintain that under existing conditions the improvement of our land system is quite impossible - that land tenure, landlordism, the helplessness of the labourers, the apathy of the farmers, rule out schemes of adequate improvement, that it is useless to put patches on the old garment: the entire system of existing land tenure must be changed before agriculture can fully come by its own. Others put their trust with more or less enthusiasin in less sweeping reforms to be enforced by the strong arm of the legislature. There is something truly pathetic in the sequence of electioneering phrases which have been employed, in many cases with all sincerity, to stimulate the jaded hopes and rouse the enthusiasm of those who sojourn in our English villages. There was once a time when 


\section{PROBLEMS OF VILLAGE LIFE}

the cry of "three acres and a cow" had a definite meaning and had not yet passed into the limbo of political absurdities.

In the concluding chapters of this book we propose to deal in summary with various suggestions brought before the country as remedies, more or less complete, for some or all of the existing ills of country life.

Before, however, any consideration of future reforms is undertaken, the impartial student of country life must acknowledge the immense value of two great and beneficent measures which have become law within the last few years. The economic position of the labourer has been signally affected by the Old-Age Pensions and National Insurance Acts.

The Old-Age Pension came as a veritable blessing to the poor toilers of the village. Our villagers hate the Poor Law, and nothing but starvation will bring them to accept the shelter of the workhouse. Until the State pension was granted as the inalienable right of a poor citizen, the menace of pauperism was always present before the eyes of something like half our old people in the rural parishes. One indirect result has brought much happiness to the parents of married sons and daughters; these old folk have been enabled in many instances by their possession of $5 /-$ a week to 
find a place at the fireside of their children, who otherwise could not have borne the additional expense, but are glad to receive their parents under the changed conditions. Where no such resource is open to the old people, the loneliness of the surviving partner is very pathetic. You will find an old man, his limbs perhaps racked with rheumatism, sitting quite alone beside the scanty fire, with his pipe and an old copy of the Christian World. His children are scattered far and wide and can pay him only rare visits, and some kind neighbouring woman may look in from time to time to "tidy up."

The pension has thus benefited the young villagers as well as their parents and grandparents. Outsidc exceptional cases of neglect or ill-treatment the claims of parents on the generosity and affection of their children are rarely repudiated. Nevertheless, this support of the older generation often imposed a severe strain on the slender resources of a young couple, whosc every penny was required for the maintenance of their own children. The severity of this economic strain has now been greatly relaxed.

National Insurance, though at first misunderstood and mistrusted by the labourer, will probably establish itself firmly in the goodwill 


\section{PROBLEMS OF VILLAGE LIFE}

of the village. To go no further, any measura which frees the country cottage from doctors' bills deserves the gratitude of the poor. Formerly in cases of illness the payment of even the humblest fees formed a crushing burden on the slender exchequers of the cottage. Three doctor's visits at 2/6, apart altogether from loss of work, would bring many families to the brink of temporary starvation and destitution. So real was the dread of these liabilities that the calling in of the doctor was frequently delayed at the risk of dangerous and even fatal results. In the case of childbirth the extra expenses formed so formidable an item that mothers frequently incurred grave injury from a too early resumption of home or field work. At present, a young couple, with, say, a new baby every two years, may find almost the whole of the contributions returned for these special needs in addition to the ordinary benefits of their insurance.

There are two obvious and primary items in any scheme of rural reform-the erection of decent cottages and an increase in wages. But the landowner who earnestly desires to see the labourers better housed is at once faced with the fact that cottage building in the country is, as a rule, unremunerative business. No cottage constructed of stone, 
brick or concrete can well be built for a less

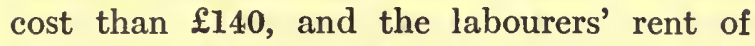
$1 / 6$ or $2 /-$ a week yields on this outlay a percentage so small that cottage building passes out of the category of business into that of somewhat expensive philanthropy. In view of rates, taxes and repairs, 5 per cent. is the minimum return which will ordinarily be required from capital advanced for building purposes : and this means a demand of some three to four shillings a week - a rent quite beyond the present means of the agricultural labourer. Here and there landowners erect sporadic groups of sound and sanitary cottages, but in almost every case the actual return does not exceed 2 per cent. or sinks to vanishing point. It is therefore quite evid nt that the solution of the problem cannot be left to the generosity of a mere fraction of our landowners who are rich enough to build cottages worth five shillings a week and let them for two. A novel proposal has been made by the Duke of Marlborough and others, that as the landowner is thoroughly well acquainted with rural needs and circumstances he should be employed by the State and subsidized from the national exchequer on the understanding that he employs the money on cottage building. It is difficult to imagine the adoption by any 


\section{PROBLEMS OF VILLAGE LIFE}

Government of a plan so thoroughly out of touch with the general spirit of modern democracy. It is certainly true that our landed gentry have in most cases an intimate knowledge of village questions: anybody who has served on a Parliamentary Committee for some rural Bill realizes that Liberal and Labour enthusiasts are sometimes handicapped in the pursuit of obviously just ideals by a sad ignorance of rural conditions. Nevertheless the impartial student of English history, while acknowledging that our landowners are well acquainted with rural needs, may pertinently ask what these experts have done to satisfy such needs?

It is therefore the strong arm of the State which must be stretched out to help our poor folk in their need. In striking contrast to the splendid work accomplished in Ireland, the efforts made in England to meet the need for good cottages have been extremely feeble. The administration of such Housing Acts as have been placed on the Statute Book has been left to the permissive action of local authorities. The result, not unexpected by those who have had experience of Rural District Councils and the like, has been ludicrously inadequate. The Act of 1890 resulted in the erection of thirty-two cottages, and from the advent 
of the Housing Act of 1909 to April, 1913, the total number is only $\mathbf{4 7 0}$ for the whole of Great Britain; at the same time this minute increase in the number of houses has been more than nullified, as far as actual accommodation is concerned, by the closing of 5,486 insanitary cottages! The Housing and Town Planning Act may to some extent meet the necessities of urban reform, but it will accomplish little towards solving the vexed question of rural housing. Take for instance one of the best examples of building under $M$ : Burns' Act in the village of Chipperfield, near King's Langley. Here, after repeated failures and rebuffs, Mr. Aronson, a public-spirited member of the Rural District Council, succeeded in getting the Act put into force. A loan was sanctioned by the Local Government Board and six excellent cottages erected at the cost of $£ 160$ each. There were three bedrooms, a large living-room and scullery, and 15 poles of garden was attached to each house. But the rent was $4 / 6$ a week, an absolutely prohibitive charge for an agricultural labourer. The Act is useless in the case of the people who especially need our help. Once more the poor labourer is left in the lurch. All that can be urged in support of such enterprize as this is that by the building of even 


\section{PROBLEMS OF VILLAGE LIFE}

half-a-dozen houses at $4 / 6$ a week the pressure of overcrowding is relieved, and that while the $3 / 6$ people move up to the new and more expensive houses, their cottages are occupied by villagers hitherto paying only $2 /-$. This of course sounds very well in theory, but the stern fact remains that in the weekly budget of the labourers' families in the badly-paid counties there is really no margin whatever from which to draw for any increase in the re .t of his dwelling.

The position of the labourer as a rent-payer is based on no sound economic principles, but is simply part and parcel of the whole slipshod system of our rural life. In the past, from motives sometimes ethical, sometimes aesthetic, landowners have built groups of superior cottages and let them at quite unremunerative rents. The existence of these model cottages at purely artificial rents has really proved a hindrance to the general advancement of rural housing. "If the money and energy devoted by generous landlords to this unhappy policy," says Mr. Nettlefold, " had been devoted to showing farmers and other employers that it is sound business to pay good wages, and see to it that they are earned, and bad business to pay the smallest possible wages, good might have resulted 
instead of harm." The provision of adequate holdings would have enabled these tenants to pay a proper rent and would have in the long run borne better results for both owner and occupier.

Public and private efforts having up to the present signally failed to remove the deep seated evils of rural housing some fresh attempt will doubtless be made on the part of the Government to grapple with these difficulties by the employment of State loans or subsidies.

There are two methods of State aid which are commonly advocated, the advance of loans on generous terms of interest and repayment, or the simple grant of a subsidy. There are practical and economic objections which may be brought against either proposal. The effects of a loan-policy in England have been signally disappointing. No such loans can be secured except on the initiative of local authorities, who as a rule are at best dilatory and apathetic with regard to the housing problem, and at worst bitterly hostile. And, further, even if the cumbrous machinery is put into motion and a loan obtained, the rents which must be charged for the new cottages are, as we have already seen, quite out of the reach of the class whose needs are more especially before our eyes. 


\section{PROBLEMS OF VILLAGE LIFE}

The theoretical case against subsidies pure and simple is still stronger. To put the question quite simply, why should a workman in Wandsworth be taxed in order to provide a better cottage for a Dorset labourer ? On what principle do you ask the vast majority of our taxpayers-most of whom are poor people-to pay further imposts in order to better the condition of a mere fraction of the population? The stupid arguments about the use of Norwegian granite and foreign leather by the State are easily answered by pointing out that a small body of Aberdeen quarrymen or British leather makers have no real claim to extract thousands of pounds out of the national exchequer for their own especial benefit.

The best reply to the formidable argument against housing grants, is that circumstances alter cases, and that abundant precedents exist for the violation of a political theory which from a strictly logical point of view is unassailable. After all, taxes are levied by the people on themselves, and if any party goes to the poll with a clear pronouncement that the evils of rural housing are so serious a menace to our national not less than our local welfare that the general revenues of the State may well be drawn upon for special grants to 
heal a special malady in the body politic, and the electorate supports this programme by their votes, little more remains to be said. Sometimes majorities are willing to suffer. Moreover it is too late in the day for any political party to denounce the policy of $a d$ hoc subsidies as such. If a declining population and the removal of the small garrison produces a depressing effect on the local trade of St. Helena, the British taxpayer helps to make good the loss. British taxes are drawn upon to provide the salary of an agricultural lecturer in the Barbadoes. More than $\mathfrak{1 6 0 , 0 0 0}$ a year is bestowed upon Uganda, and other subsidies are lavished freely on the mining and cotton growing in Nigeria. Five millions of British money were sunk in the railway to Nairobi ; three millions have been advanced to assist cotton-growers in the Sudan. Nor need we travel so far. The history of our financial relations with Ireland affords ample precedent for the employment of the national revenues for the benefit of a minority of the population which is too poverty-stricken and helpless to raise itself to a decent level of existence. Nor is it probable that any serious antagonism would be manifested towards a scheme of subsidies for rural housing. The relief afforded to the landowners and farmers 


\section{PROBLEMS OF VILLAGE LIFE}

by the Agricultural Rating Act was, it is true, keenly resented by a large section of the urban population, but in this case it was held, rightly or wrongly, that no valid claim had been made out by those who claimed exemption from half their rates at the expense of the general community. The claims of the agricultural labourer on the other hand are so unquestioned and his grievances so well founded that grantsin-aid in order to give him a decent cottage would probably be accepted if not with general enthusiasm at any rate without widespread protest.

The system adopted in Ireland combines the two policies of loan and subsidy, and perhaps supplies the best possible method of employing national funds for the carrying out of a thorough reform in rural housing.

Money is advanced by the Land Commission on generous terms-3 $\frac{1}{4}$ per cent. to cover interest and the repayment of the loan in $68 \frac{1}{2}$ years. Under this beneficent legislation more than 40,000 cottages have been built or are in process of being built. The loans advanced for these purposes amount by this time to the huge total of $£ 7,860,939$, and as the rents charged are very low, ranging from $6 \mathrm{~d}$. a week in some places to $2 /-$ in the neighbourhood of Dublin, the interest cannot be 


\section{HOMES AND WAGES}

155

met except by a rebate, so to speak, of some 36 per cent. of the income due to the State. In other words the national exchequer makes an annual present to the people of Ireland of $£ 81,000$. The changes effected by this bold finance are wonderful : it is not an exaggeration to say that the face of rural Ireland has been transfigured. The neat, well-built, slateroofed homes which have taken the place of Ireland's squalid hovels have given fresh hope and encouragement to the agricultural population and the exhausting flow of emigration is at length checked.

Why then in the face of these manifold blessings conferred on Ireland by wise and humane laws, should the cry of the English villager continue to be a vox clamantis in deserto? The three real obstacles to a satisfactory scheme of rural housing have been, the absence of adequate funds, the obstinate hostility of local authorities and the unwillingness of legislators to alienate the goodwill of the propertied classes. But power must inevitably pass from the hands of those who admit such limitations. The opposition of local councils who are not really representative of the districts must be swept aside by central authorities who " mean business." The solution of our rural housing problem is a matter 
of vital urgency, for day by day the conditions are becoming worse instead of better.

It is, however, useless to talk about good cottages with an "economic rent," or advocate an extension of the school-age, to men earning from $12 /$ - to $15 /$ - a week

What is at the root of their economic misery - what is it that denudes our villages of the young and active, that condemns those who remain to dwell too often in damp and dilapidated hovels, that allows the minds and souls of our villagers as well as their limbs and muscles to be controlled by their employers, that crushes out their independence by a system of degrading patronage? The principal cause of all these evils is simply the payment of low wages. Can anybody deny the facts? If we exclude harvest and hay money-which is almost invariably extra payment for long stretches of overtime, and specially laborious work-and various " allowances," differing widely in kind and amount, according to local custom, but in any case a vicious method of giving wages-the average income of our agricultural labourers stands at a very low level. There is then one essential factor in the betterment of the labourers' lot and that is-higher wages. If the Government can help the comparatively well-paid and highly- 
organized miners to secure better remuneration, its strong arm may well be stretched out to assist the sweated toilers of the countryside. That agricultural labour may be fairly described as "sweated" few could deny.

Why should this be so? For forty years the wages of agricultural labourers have been practically stationary. The days of acute agricultural depression are past, and it is very unlikely that they will ever recur ; it is difficult to suppose, for example, that wheat can ever again drop to 26/- a quarter. As a matter of fact farmers are at present doing very well and have been prosperous for the last six years. At the same time the cost of living has indubitably increased, and the purchasing power of the labourer's poor wages is no longer what it was ten years ago. An amazing increase has taken place in our national riches, more is spent every year from the advancing incomes of the wealthier classes in luxury and display, and pari passu the industrial population has gradually and painfully succeeded in making good its claim to a slightly larger share in the wealth which it produces. The poor toiler of the country-side is, however, left out in the cold. The means which have helped his fellow-countrymen are denied to him ; his poverty, his lack of mental 


\section{PROBLEMS OF-VILLAGE LIFE}

energy, the loneliness of his hamlet and cottage-all these things tend to neutralize the value of his citizenship and hamper any collective effort for better wages.

The case for a legal minimum wage is indeed stronger than would appear from the official figures. It seems that the local returns of wages in cash and kind were very largely derived from landowners, land-agents and farmers, who naturally tend to furnish as high an estimate as possible of the wage bill. In the case of Bedfordshire, e.g., Mr. Wilson Fox's figures for the labourers' wages in the Government returns are obviously much too high. Mr. H. H. Mann has by most careful tests shown that in 1899-1900-and there has been practically no change since-the average earnings of the ordinary labourers were not 15/5 as Mr. Wilson Fox declares, but only $13 / 7 \frac{1}{2}$ ! Further, no adequate allowance appears to have been made by Mr. Wilson Fox for that highly important item, wet weather, and the sad losses of time occasioned by this factor in so variable a climate as our own. "Hundreds of Northamptonshire and Oxfordshire labourers," says Mr. George Edwards, "go home at the week-end during the winter months with only $8 /$ - for the week."

Owing to the gradual rise in the cost of 


\section{HOMES AND WAGES}

living during the last twelve years the economic position of the labourer has grown worse. While practically no change has occurred in his wages - a rise of 3 per cent. at the outside -the price of provisions has risen by 10-15 per cent. The real wages are to-day lower than they were in 1900 .

A minimum wage for agricultural labourers must be secured by legislation. The principle of this has already been admitted by the Government and has found practical expression in the case of our miners, apart from the changes effected in the case of certain sweated industries under the Trades Boards Act.

It is indeed difficult to resist the claim of our farm labourers in this matter, or to refuse them in their poverty a privilege accorded to our much better paid coal miners. At any rate, it is no valid argument against such a policy that it is impossible to fix one wage for the labourers of, say, Norfolk and Durham. Nobody has ever suggested this; all that is required is the fixing of the wages in different parts of Grcat Britain by a Central Authority in accordance with local conditions in the county or other administrative area. Members of West End Clubs, lounging in armchairs, tell you that agricultural wages are fixed by the economic laws of supply and 


\section{PROBLEMS OF VILLAGE LIFE}

demand. But no conceivable law of political economy accounts for the fact that labourers of Devonshire receive 17/9 a week and those of Oxfordshire 14/11, all included. The whole wage system in vast areas of rural England, where no outside competition is met with from neighbouring factories, mines, docks, sea-fisheries, etc., is largely determined by mere usage and local precedents. And it is simply due to the lack of organization and combination amongst our farm labourers that these divergencies in payment and the wretched wages themselves have persisted so long.

As a minimum wage for our agricultural labourers is an absolutely necessary item in any genuine scheme of rural reform, it may be necessary to include in the programme the establishment of Land Courts, which shall determine the amount of the farmer's rent. There are tenant-farmers here and there who will acknowledge that agricultural wages cannot continue on their present scale, but they are prevented from putting their theories into practice and augmenting the weekly wages of their men by two considerations. There is the economic reason that they cannot afford such an increase in the weekly wage bill, and the social reason that an insignificant minority of farmers cannot change the 


\section{HOMES AND WAGES}

normal rate of wages against the wishes of the majority.

Whatever may be alleged to the contrary by certain economists, the common-sense view of agricultural rent is that it consists of what remains over after the labourer has secured decent conditions of life and a living wage, and the farmer a fair return for his energy and skill. We have hitherto in England begun at the top instead of the bottom. Our landlords have to a large extent arranged their rent-rolls without adequate regard to the question whether or not the subordinate classes in the rural community could or could not obtain a reasonable competency. Some startling examples of this are, of course, furnished from the experiences of the Corn Laws period. When the price of wheat was artificially raised by heavy taxation, when at one time no wheat was permitted to enter our ports until the home price reached 80/a quarter, when money was pouring into the pockets of our landlords, and a large percentage of our great country mansions were built-at this time farmers were continually driven to bankruptcy by heavy rent burdens, while thousands of our labourers lived in misery on $8 /-$ a week.

For the establishment of Rent Courts in 


\section{PROBLEMS OF VILLAGE LIFE}

England we possess sound precedents in Ireland and Scotland, nor is there any valid reason against such a policy. At any rate, it is clear that if anybody is to suffer pecuniarily in the reconstruction of rural life, it shall notgenerally speaking-be, in the first instance, the farmer, nor in any case the underpaid labourer. The completion of the Land Valuation will be a great help in the work of establishing Rent Courts; and on the basis of a living wage for the labourers the amount of rent to be demanded from the tenant will be settled, not on haphazard caprice, but on just and definite lines.

If the landlord complains, as he is sure to do in many cases, that he cannot afford to live under a system of reduced rents, the remedy is obvious. Experience has taught us that such outcries, even when sincerely believed in, are usually unreal. How many country houses have been closed since the passing of the Budget, how many horses have been sold (except to replace them by costly motor-cars), how many footmen dismissed, how many coverts denuded of their handraised pheasants ? But if the landlord cannot afford to retain his estates, let them be purchased on the basis of the State Valuation by the issue of National Bonds. 


\section{CHAPTER VIII}

\section{SMALL HOLDINGS}

WITH the bestowal of the labourers' franchise in 1884, it became quite clear that the country districts could no longer be ignored by Parliament as they had been in the past. Hence we find from this moment a series of measures, the ostensible object of which was the provision of land and houses for the needs of the rural population. An Act to enable " charity" lands to be used for allotments proved almost a dead letter from the start. This was followed, in 1887, by an Allotments Act, giving compulsory powers of acquiring land to Sanitary Authorities, in whose hands, how-

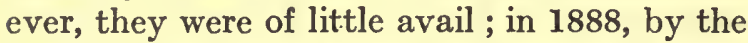
Local Government Act which created County Councils; in 1890, by the Housing Act and an improvement of the Allotments Act; in 1892, by the Small Holdings Act; and in 1894, by the Local Government Act, creating Parish and District Councils. All these measures were symptoms of a new ideal, held some- 


\section{PROBLEMS OF VILLAGE LIFE}

times consciously, more often unconsciously. Such efforts were, in theory, designed to give the labourer some interest in the land, to attach him to his village; but they were for the most part timid and half-hearted measures, some of which were apparently devised as mere political window-dressing, and were never intended to effect more than an absolute minimum of change. The failure of this earlier legislation was indeed notorious. Thirty-two cottages were built under the Act of 1890 ; that of 1892 secured 880 acres in fifteen years!

Any real "colonization of England" by the creation of a large number of small holdings would not be the establishment of a wholly new order, but rather the restoration, under new forms, of an old one. To any one with a sense of history, the transformation of rural England into a country of large farms, worked by proletarian labour, is a purely modern movement. The old social economy of the countryside, which survived intact until the middle of the eighteenth century, was one of small farms and communal agriculture. It required, no doubt, considerable changes of form to bring it into harmony with the new circumstances of the national life. But what we did was to break it down deliberately, 
by legal enactment, without building up any stable society in its place. Our present condition is not, as some contend, the product of merely economic forces : it is the product of law, modified by economic forces. The Enclosure Acts; the law of Entail ; the law of Intestate Succession; the old Poor Law, assisting the large farmer by grants in aid of wages; the Corn Laws, encouraging the breaking up of commons; the Game Laws, promoting sport on a large scale-all played their part in the long tragedy of destruction. The central fact in the mind of any Land Reformer must inevitably be that the monopolization of our English land was brought about entirely by a long series of legal enactments: the central purpose, that wrongs inflicted by law can be, and must be, remedied by law. The advocate of a greater subdivision of our soil for the benefit of a larger number of persons, although he knows the story of the English land and believes that millions of acres have been filched from the poorer folk by violence and chicanery, is yet quite content to pay a fair price for the repurchase of this land for public purposes.

Few impartial students of rural life have denied the existence of a very real desire to 


\section{PROBLEMS OF VILLAGE LIFE}

secure small holdings, or the value of these under favourable conditions. Nevertheless the whole course of the movement is strewn with the wreckage of failure. So deeply rooted is our national veneration for vested interests, even when these are founded on past wrongdoing and present menace to the community : so potent is the influence of our landed classes, that no legislation has yet succeeded in making any sensible impression on the land monopoly of rural England.

The ignorance or indifference of our urban populations as regards rural matters, the open hostility of the farmers, the apathy or dislike of landowners and land-agents-all these factors have been brought to bear against the success of a small holdings policy. One is constantly met in country districts by the assertion that small-holders cannot succeed in England, a verdict which seems paradoxical enough in view of the facts of British colonization. The same people who regard our village poor as inherently incapable of managing a bit of land are the first to extol and even exaggerate the efficiency and prosperity of this very class when it comes to emigration. These same men, we are told, do wonders in New Zealand or Australia. They can earn a good living after stubbing up tree 
roots from farms of 160 acres in Canada, but in England they do not possess enough intelligence to look aftcr five or ten acres! To some members of our richer and more comfortable classes the English poor appear feeble and vicious except when, by transference to the colonies, they are suddenly metamorphosed into "Empire builders." Colonials in dented hats and coloured shirts are constantly presented to us by Mr. Rudyard Kipling and his school as infinitely superior beings to the inert and effeminate inhabitants of these islands : as if, to go no further, the hard life-struggle of an agricultural labourer were not quite as "strenuous" as that of a cowboy or rancher!

But quite apart from colonial analogies, abundant proofs exist in England itself that small holdings can and do succeed under reasonable conditions. These conditions vary considerably; and sometimes afford good prospects of success in spite of the absence of good soil or a specially favoured climate. One such factor, for example, is the proximity of a market; another, the existence of Common rights; a third, the possibility of obtaining in the neighbourhood some kind of piecework, by which the small holder can supplement the earnings of his farm. Some 


\section{PROBLEMS OF VILLAGE LIFE}

examples may be cited of such varied types of small holdings.

In 1895 the Lincolnshire Small Holdings Association leased from Lord Lincolnshire a farm of 250 acres on the fen lands in the south of the county-a district rich in its soil but flat and monotonous to the eye, and intersected, not by hedges, but by the deep dykes which serve to drain it. They let the land in plots of from forty acres downwards to the members of a Small Holdings Club, which had previously been formed at Spalding among labourers and others who were anxious to have a piece of land of their own. The old farmhouse was adapted to accommodate two families. The farm buildings (an example which has been followed with great advantage in other places) were divided up into no less than seven portions, the farmyard presenting a star-shaped appearance with railings which meet at the pond in the centre. The arable land has needed no division; but the grass has been divided by post and wire fences. This and other expenses necessitated by the division of the land have been incurred by the Association, and have been repaid by their tenants in the form of a slight addition to their rent. After ninc years, the unpaid rents amounted to $£ 6$ s. only, out of a gross rental 


\section{SMALL HOLDINGS}

from 202 tenants of $£ 1,323$. The most conclusive evidence of the value of these holdings is the constant demand for more land. Concurrently with this experiment there has been a considerablc increase of small farmers and allotment holders, tenants either of Lord Lincolnshire or the Holland County Council. The effect on population in nineteen parishes round Spalding has been remarkable. In 1881 it was 38,000 odd. In 1891 it had decreased, like that of so many agricultural districts, by 2,282. But from 1891 to 1901 it decreased only by $\mathbf{1 1 5}$.

This is an example of holdings which have succeeded mainly through the fertility of the fen lands on which they are situated. Other examples could be given-that, for instance, of the strawberry growers at Calstock, in Cornwall, on the southern slope of the charming valley that runs down to Davenport-in which success has been due to the suitability of the situation for some spccial crop.

As instances of small holdings which owe their success to their nearness to markets, we may quote those in the neighbourhood of Bath and those in the Dartford district of Kent, which runs up almost into the southeast corner of London; those at Rew and Winterslow ; and those of Verwood, in Dorset- 


\section{PROBLEMS OF VILLAGE LIFE}

shire, where the small-holders are "squatters" on moorland which they have themselves reclaimed.

The small holdings in the neighbourhood of the New Forest are a striking instance of the advantage of common rights. These holdings, on which a whole family can be supported, average about twelve acres. This acreage might not be sufficient to support the family if the stock had to be kept upon it all the summer. But as they can be then turned out into the Forest, the holding can be used for growing the feed which keeps them when they are brought in for the winter.

The experiment at Winterslow illustrates the importance of the supplementary earnings which are made by labour off the farm. The work in the woods and the industry of hurdle making provide these small-holders with a very useful adjunct of profit to thcir farms, and this condition alone has probably been enough to make the experiment a success.

And apart altogether from these special factors of success, there is hardly a village in which it will not pay some of the inhabitants, such as tradesmen, publicans, carpenters or blacksmiths, to have a small piece of land within easy reach of their houses. Such holdings, though they may not directly pro- 
vide for a larger population, give the younger generation a taste for country pursuits, and often enable their possessors to retire from business earlier than they would otherwise do, making a partial living out of the soil and leaving their places as retailers or workmen to be filled by others.

The usefulness of such holdings, even on light and comparatively poor land, is illustrated by the success of the Norfolk Small Holdings Association, formed in 1900. Here three farms, making a total of 338 acres, were purchased and let to sixty tenants. There are no special advantages in the way of soil, climate, markets, common rights or outside labour. But the land is conveniently situated for those living in the villages. Norfolk is a county in which the tradition of small farms and the desire for the land have survived more vigorously than in other parts of England. The experiment has been highly successful. The rents are promptly paid; there is no evidence of tendency to throw the land back into large farms; and, if the population is not increasing, at any rate the exodus is bcing stemmed.

The success of small holdings, where certain conditions exist, has thus been proved beyond the possibility of doubt. Object-lessons lie 
scattered throughout the country, from York to Cornwall, and from Kent to Shropshire. In the rare cases where land divided into small farms has reverted to large, not one of the special factors was present which I have noted as likely to ensure success. Yet these factors have been shown to be no exceptional combination of advantages, but so common that there are probably but few parts of England in which one or other of them does not exist.

The following extract from the Annual Report by the Small Holdings Commissioners (1912) is full of interest as showing what can be accomplished by skill and industry on a small holding of only seven acres.

"The land of the district is a loam, varying in texture from a light, free-working soil, to a_stronger soil on suitable clay for standard fruit trees. The land tenanted was bare on entry, and some of it was in poor condition. The seven acres are cultivated now as follows :-

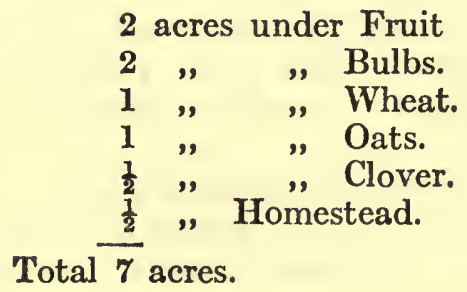




\section{SMALL HOLDINGS}

"The Home holding (in the village) covers about half an acre of land. This is occupied by various buildings, a flower garden, stackyard, poultry-run, and a vegetable garden, in which several fruit trees are planted. The house is a roomy old cottage. All the outbuildings were erected by the tenant at his own cost. They are timber-built and are roofed with glass, wood, or corrugated iron. "The tenant pays a rent, inclusive of rates, of 10 guineas a year for the Home holding, 5 guineas an acre and rates for the land planted with fruit trees, and 50/- an acre and the rates for the bare land which he himself has planted with fruit trees or bulbs. The total rent, exclusive of rates paid for the seven acres and the cottage, is $£ 31$ 15s. 6d. a year.

"One horse-a strong cob-is kept. This horse is able to plough and work the land, take the trolley to the railway station, or the light cart to the market. Hired team labour is required, as a rule; only when the wheat and oats are drilled. The whole of the bulb land and part of the land under fruit is under spade cultivation.

"The tenant and his married son are fully occupied in cultivating the seven acres. An extra man is employed occasionally. Other members of the tenant's family assist at 


\section{PROBLEMS OF VILLAGE LIFE}

busy times, especially at the fruit-picking and bloom-gathering seasons.

"The tenant keeps pigs; but, having no grass land, a cow is not kept. If a paddock were available, it would be very convenient for the horse in summer, for a cow, and for the poultry, which would pick up more insect food and be healthier than in the confined poultry-run. In the circumstances, half an acre of arable land is reserved for clover, cut green for horse food in the summer and partly made into hay for winter supply. The oats are grown for horse corn, while the oat straw is cut into chaff. The oats not required are sold. The wheat is sold, the straw being carefully husbanded and used for bedding the horse and pigs and for covering potatoes kept through the winter.

"Sufficient yard manure is made for the arable land. For special vegetable crops, artificial manure is used in addition to the yard manure.

"The tenant sells fat pigs but retains sufficient for home consumption. Eggs are also sold. Formerly home-grown wheat was kept for domestic use, but the practice of grinding wheat at the village mill has ceased. Hence, the flour for home-baked bread is bought. Substituting for the flour home- 
grown wheat of a corresponding value, it will be seen that the tenant is able to produce on his holding practically all his requirements for home consumption, viz., bread, bacon, poultry, eggs, potatoes, fruit and green vegetables, together with jams, pickles, and bottled fruits. This is probably equivalent to half the cost of living. If a cow were kept butter and milk could be added to the list.

"The tenant grows for the market the following fruits:- strawberries, black currants, gooseberries, raspberries (dwarf canes), plums (Victoria), eating apples and cooking apples.

"The bulbs comprise about twenty-five varieties of the Narcissus group and several kinds of tulips. Beginning twelve years ago with a small stock in the garden, the tenant has gradually accumulated a stock sufficient to plant fully two acres of land. Purchases of bulbs have been made from time to time, and the stock may now be worth from $£ 400$ to

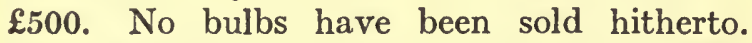
The varieties have been so selected that the tenant can keep up, in a normal season, a continuous supply of blooms for about ten weeks, commencing at the end of January."

What a signal instance of the real value of a small farm in the hands of a capable and 


\section{PROBLEMS OF VILLAGE LIFE}

steady man, and despite the handicap of a heavy rent! Other striking examples of successful small-holders are given by the Commissioners, whose enquiries have resulted in highly satisfactory reports as to the high class cultivation of the holdings. Conclusive testimony is also borne to the sterling integrity of the average small-holder as regards the payment of his rent. "On the whole, it may be said that the small-holders have come through the ordeal very creditably, and that their record will compare favourably with that of the general body of farmers."

Fresh ipplications for small holdings, which in England average from thirteen to fourteen acres, still continue, and, as we have seen, thousands of applicants are still unsatisfied. But as regards the land hunger for lesser plots of ground, in the shape of allotments, the demand has to a large extent been already satisfied. That allotments may at times, e.g., when pigs are kept, prove of real benefit to the labourer, is unquestioned. On the other hand, this means of adding to the labourer's income is frequently precarious and unsatisfactory. The care and cultiva. tion of allotments at considerable distance from a man's home is generally tedious and difficult, while the rent charged for accommo- 
dation land near a town or village is often exorbitant. Every one knows of allotment holders who pay at the rate of $£ 2$ to $£ 3$ per acre, while the farm land over the hedge yields from $10 /-$ to $\mathfrak{E} 1$. Few allotments can be adequately worked unless the holder gives up several days a year from his ordinary occupation in addition to a shocking amount of overtime after the normal day's labour is finished. The returns too are often exceedingly meagre. Here are the statistics from Mr. Mann of some allotments in Bedfordshire, where the soil is fairly good, and potatoes are considered the most profitable crop-each of the two being one-eighth of an acre in extent.

No. 1 (better land). Average crop, twentyseven bushels of potatoes at 2/-per bushel, £2 14s.

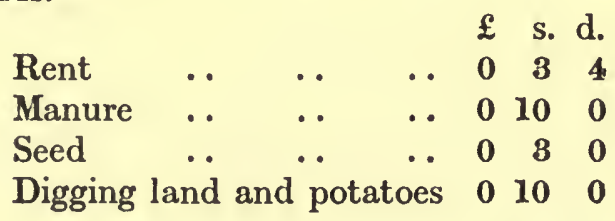

£1 $6 \quad 4$

Profit, £1 7s. $8 \mathrm{~d} .=6$ d. weekly! 


\section{PROBLEMS OF VILLAGE LIFE}

No. 2 (inferior land). Fourteen bushels at 2/- per bushel, $\mathfrak{1 1} 8 \mathrm{~s}$.

\begin{tabular}{|c|c|c|}
\hline Rent & .. & $\ldots$ \\
\hline Manure & .. & .. \\
\hline Seed .. & . & .. \\
\hline
\end{tabular}

Profit, $11 / 10=3 \mathrm{~d}$. a week !

The general atmosphere of hostility in which the village applicant for a small holding frequently finds himself is the outcome of several deeply rooted prejudices. The landlord is, as a rule, far less opposed to the subdivision of his land than the land agent or the farmer. Nevertheless, as an ardent supporter of the Conservative Party, he naturally tends to regard Liberal measures with suspicion and dislike, and in many cases he is sincercly convinced that sooner or later his land will be subjected to heavy and special forms of taxation or even taken from him by some obscure processes of what he vaguely calls RadicoSocialism. Further, the sporting squire realizes that extensive game preservation and intensive farming are incompatible, and that in general any far-reaching extension of 


\section{SMALL HOLDINGS}

small holdings in England would seriously curtail the possibilities of sport on a large scale. In the case of certain land required for small holders at Piddington, in Oxfordshire, one of the chief objections raised was that sport would be interfered with by the creation of the holdings.

"Up to last year," says a villager in Shropshire, "we have had very few foxes in this district, so few indeed that - has given twelve acres of land to be planted with gorse - so we may expect plenty of foxes in the future." Men wait in vain for land in Shropshire, upon which they and their families may live, but a breeding place for foxes is willingly granted.

On the other hand, some of our great landowners, less selfish or more foreseeing, sympathise with the reasonable ambitions of their humbler neighbours, or believe in the business value of small holdings. The present Duke of Marlborough, e.g., has openly acknowledged his convictions that there are few inducements to accept the existing conditions of the countryside, and that a greater subdivision of the soil is necessary if the rural exodus is to be checked. As to the practical side of the question, there is ample evidence to show that, from the point of view of rent, 


\section{PROBLEMS OF VILLAGE LIFE}

small-holders are usually willing to pay more for their land than the larger farmers and pay it with greater regularity and certainty.

Of far greater intensity than any antagonism of the land-owners is the general attitude of the land agents, who, apart from the general sentiments of their class, realize that their work would be largely increased by any large creation of small farms. It is naturally much easier and more pleasant to deal with a comparatively few big farmers and collect a few large rents than to be exposed to the grievances and demands of a crowd of "small men" and the trouble of extra book-keeping involved in a large number of small rentpayments.

The farmer, in addition to his innate conservat sm and a strong class-feeling in his attitude towards the labourers, has special and personal grievances against any large policy of small holdings. His available supply of labour is already sadly diminished in many parts of the country by the gradual depopulation of the villages, and will be still further menaced by the conversion of his regular employés into small farmers, who can merely furnish him, from time to time, with casual help. A keener distrust arises from the fear that some of his farm will be taken 
from him, as must necessarily be the case unless the selection of land by small holdings authorities be strictly confined to farms rendered vacant by surrender or death. Even if the demand for additional land affects only a small fraction of a farmer's acreage, he complains, and sometimes with reason, that the area he is asked to give up is the best portion of his land, the " eye " of his farm. The applicant has, as a rule, a keen appreciation of the difference between good and bad land. He is not going, if he can help it, to be put off with the worst fields, " brashy" gravel-soil, heavy " three-horse" clay, or the coarse turf of marshy land. The only course is one of sweet reasonableness. The farmer must realize that minorities must needs suffer in promoting the common welfare and that individualism is a declining force in the modern world. The small-holder too must submit to reasonable "give and take" in his demands. Parliament has done something to meet the farmer's grievances by granting him compensation for " compulsory acquisitions" and "severance;" and the conflict of interests between the farmer and the " approved applicant" would have been greatly relieved had the County Council made any serious endeavour to build cheap 


\section{PROBLEMS OF VILLAGE LIFE}

houses on vacant farms suitable for small holdings. In the absence of such houses applicants cannot utilize land at any considerable distance from the villages where they already live.

Apart from the question of the administrative machinery for the creation of holdings there exists a fundamental controversy as to the conditions of tenure best suited to these farmers : are they to hold the land as freehold owners or as tenants of a public authority? This clear issue has unfortunately been obscured to a large extent by considerations of political partizanship. Ownership of property in general and land in particular has always been regarded as a valuable asset by the Conservative party, whose supporters have not hesitated to express their confident belief that a vast increase in the number of "peasant proprietors" would provide a stout bulwark against the assaults of "revolutionary" movements. "A war of classes is being proclaimed," says Sir Gilbert Parker, a vigorous advocate of ownership; " a crusade against property . . . is being preached; people's minds are being turned from effort to revenge-to Socialism." This dangerous tendency is to be countered by the establishment of numerous small owners, jealous 
guardians of the rights of property and keen advocates of protective legislation. The Conservatives have ample justification for their belief. We all realize the immense influence exercised by the agrarian policy of Germany's freeholders. A telegram from Russia appears in the Times-" Everywhere the peasants readily avail themselves of the facilities for becoming freeholders. M. Stolypin hopes thus to secure an army of yeomen who shall form the main guard of a constitutional realm." On the other hand, some, at least, of those who warmly advocate tenancy as the preferable solution are no doubt led to that conclusion, in some measure, by their social and political sympathies. In the eyes of these reformers the day of individualism is past, and the future welfare of the commonwealth lies in the beneficent application of State collectivism : amid the political atmosphere of Old-Age Pensions, Free Education, National Insurance and the like, it would be a sheer anachronism to allow the evil influence of private ownership to be extended more widely than ever over the land of England.

Outside the area of a priori sympathies and political partizanship a case can well be made out by each set of reformers. The "owner- 


\section{PROBLEMS OF VILLAGE LIFE}

ship" school can point to the "magic of property" and the incentive furnished by independent control. In the eyes of these enthusiasts, the labourer, once allowed to own as well as till the soil, develops latent powers of industry, patience, and efficiency. "It is something," says Juvenal, "to have made oneself master of a single lizard."

The advocates of the freehold are also entitled to point out that at present the small-holders in England under the Act of 1907 are in reality buying their land not for themselves but for the Local Authority. Not only the interest on the money advanced by the State, but the sinking fund also is provided out of the small-holder's pocket, with the result that at the end of the time period the holding will become the absolute property, not of h mself or his son, but of the County Council. This has always been a hard saying in the ears of our villagers, although the annual burden of the sinking fund amounts to the trifling sum of 4/9 per cent. As the Act allows the sinking fund to be paid by the County Councils, it is difficult to see why all these bodies have not followed the example of Glamorgan and a few other counties in meeting this small additional burden from public funds, in view of the valuable 
land which will ultimately become public property.

On the other hand, the advocates of tenancy possess a formidable array of arguments based not only on future contingencies, but past experience. In reply to the undoubted fact that present tenants are really purchasing the land for the county and not for themselves, they point out that the very small sum involved in this gradual purchase is not an excessive acknowledgment for the use of cheap public money by a small section of the community; and further that ultimately the effect of public ownership will naturally be the reduction of rents.

Further, inasmuch as all existing proposals for ownership involve the necessity of a money deposit-and it is difficult to see how this could be dispensed with-the available capital of the applicant would, it is maintained, be more usefully employed in stocking his small farm than in bringing about the ultimate purchase of the holding fifty years hence for a son or grandson. The tenant's security of tenure is equally good with that of the prospective owner, and he possesses the enormous advantage of being able at any time to leave his holding by reason of failure, change of plans or any other vicissitude which may arise. 


\section{PROBLEMS OF VILLAGE LIFE}

Legislative proposals of the future may, of course, render the process of freehold ownership more attractive for our smallholders, but at present there can be no doubt that the opinion of practical agriculturists is overwhelmingly in favour of tenancy. ${ }^{1}$ The history of our country too is full of warnings against the re-establishment of the very system of small ownership which failed so signally in the past. Some of the causes which brought about the disappearance of the ancient freeholders, e.g., the Enclosure Acts, have, of course, ceased to be operative. But the small owner is still exposed to special risks of failure. These arise from the factto use Mrs. Wilkin's words-that "Iand in small lots is in demand at prices above its purely agricultural value. The small freeholder, helped on to a holding at agricultural prices by State aid, is at the mercy of temptations to part with it owing to the enhanced value offered by neighbouring landowners with game preserves to be kept quiet, by town gentlemen qualifying for the position of landed gentry, by the retired tradesmen with money to invest, by the week-ender on the look-out

1 Of 23,122 approved applicants for land under the Small Holdings Act of 1907, only 2.7 per cent. desired to purchase their holdings. 
for his country cottage. It cannot be denied that up till now either the temptation to realize has proved irresistible (as is already proving the case in Ireland), or, on the holding coming into the market at the death of the owner, it has been bought at a price prohibitive to the small agriculturist."

One of the main obstacles with which the small-holder is confronted in this country is the great rise in the price of agricultural land, which almost invariably accompanies any demand for private land in the common interest. By a grave omission in the Small Holdings Act of 1907, no limit was placed on the number of years' purchase when land is acquired for public authority. The result has been that the valuers, who, as a class, are largely identified with the interests of property, have in many cases awarded values which have either rendered the acquisition of the land impracticable for small holdings purposes or heavily handicapped the small-holders by unreasonable rent-charges. A farm of 153 acres was purchased by the County Council of Shropshire. The price of this farm at twenty-five years' purchase would have been $£ 30$ and at thirty years' purchase $£ 36$ per acre: the price allowed by the valuer was

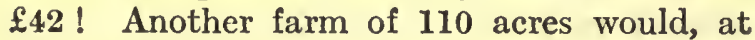




\section{PROBLEMS OF VILLAGE LIFE}

twenty-five years' purchase (a high estimate in itself), have been bought for $£ 28$ 15s. an acre: the valuer fixed the price at $£ 47$ ! Over and over again, land let to a farmer has, when used for small holdings, been let for more than double the original rent. It is true that in some cases the farmer's rent was an average one for all his fields, good, bad and indifferent, whereas the small-holders' plots were taken from the good land only. But when we have made all allowances for this and for a certain enhancement in rent charged for " accommodation land," the fact still remains that small-holders have frequently been exposed through the weakness of the Act or the unsympathetic attitude of the central or local administrators to rent-charges so unreasonably high as to militate against their success from the start.

It is difficult to see on what grounds the advocates of the "freehold" solution find encouragement from Continental analogies. It is doubtless true that the majority of the rural inhabitants of Europe own the soil which they cultivate. Nevertheless the magic of property has often lost its glamour under the pressure of bad seasons and the moneylender. In many parts of Norway it is difficult to find a small farm which is free 
from mortgage debts. M. Leconteur, the French professor of Rural Economy, states that three million proprietors of French soil are on the pauper roll, and 600,000 so poor that they are practically unable to bear any form of taxation. According to Mr. Rowland Prothero, one of our best informed writers on agricultural topics, "the French peasant proprietor is in general worse housed and worse fed than the English labourer." Baron Sournino declares that " in Italy, that portion of the rural population that does not seek exile, plunges deeper into misery day by day." In Denmark, the small farmers have incurred a grievous burden of mortgage debts to the sum of $\mathfrak{f 6 0 , 0 0 0 , 0 0 0 - n o ~ l e s s ~ t h a n ~} 55$ per cent. of the total value of their lands, houses, stock and implements. Even in England itself Mr. Wilson Fox reports that "the general conditions of the small freeholders in the East of Lincolnshire is that they are working like slaves to earn interest for money-lenders."

The record of the County Councils with reference to housing demands is equally unsatisfactory. There has been no genuine effort to carry out the "housing " clauses of the Act. The 1909 Report declares that "very few of the applicants are willing to move from their immediate neighbourhood." 


\section{PROBLEMS OF VILLAGE LIFE}

One of the reasons at the root of this unwillingness is the simple fact that the applicant has little prospect of securing any other house if he abandons his present dwelling. Over 3,000 applicants had asked for houses. In Cheshire 109 applicants out of a total of $\mathbf{1 5 0}$ wished for cottages on their holdings; in Northumberland 166 out of 274 , and so on. What is the net result of this large demand ? Not a single cottage was apparently built by any County Council in 1908, and in 1909 the grand total amounted to seventy-four, while of these no fewer than thirty-five were built on a single estate. The figures at the present moment (1912 Report) stand as follows-488 cottages actually built in five years. It is true that no direct obligation, in this respect, is imposed by the Act on the County Councils. But what the figures and facts prove is that, speaking generally, the County Councils carry out the provisions of the Act in a dull and grudging spirit, without a spark of real enthusiasm or any ardent desire to render the Act that widespread blessing which it might become in more sympathetic hands.

Cabinet Ministers have referred to the results of the Small Holdings Act as if they were eminently satisfactory, and, no doubt, an excellent case can be made out, if we are 
content to contrast them with the miserable outcome of the Act of 1892-880 acres in fifteen years. But this line of argument is not adequate for the reformer who means business. The Act in question was of the "shop-window" type : it was never seriously intended to subdivide the soil of English landlords, and it fulfilled its negative purpose admirably. The acquisition of $\mathbf{1 5 5 , 0 0 0}$ acres since the passing of the Act naturally provides a forcible contrast to the puerilities of Tory "Land Reform;" but these statistics will, in hundreds of English and Welsh villages, be received without a vestige of enthusiasm. It is, of course, no consolation to an Oxfordshire or Berkshire labourer who has waited patiently for years without any tangible result, if he learns that much has been accomplished in Cambridgeshire or Norfolk. The one bitter fact for him is that since the initial meeting when he was accepted as an "approved applicant" he has been treated with contemptuous neglect. The figures recently published speak for themselves. What sincere reformer can be satisfied with such results and prospects? "Hopes," say the Commissioners, "have sometimes been encouraged which have proved impossible of realisation." What hopes, and why impossible? After all 


\section{PROBLEMS OF VILLAGE LIFE}

the enthusiastic meetings and speeches which preceded the Small Holdings Act-speeches by Ministers of the Crown and many of their followers in both Houses of Parliament-the rural population was most certainly entitled to expect a great deal more than what has been achieved by this measure. Our agricultural labbourers form one of the most neglected classes of the community. From generation to generation they have been neglected or misled by empty promises. Their endurance has been amazing. They have waited for the realization of their simple ambitions, and preserved their souls in patience, but Home Rule and Welsh Disestablishment and other distant things have intervened again and again between these humble aspirants and the shifting vision of better things to come. Then came that annus mirabilis, 1906, and the labourers were roused from the political apathy which had followed the enthusiasm of Joseph Arch's days. "Old-Age Pensions" and "Access to the Land" became the war cries of those who felt their hearts touched by the pathetic history of a Suffolk or Oxfordshire labourer, and longed to see him freed from the petty tyrannies and degrading patronage which too often encompass his career from the cradle to the grave. Old-Age Pensions, thank 
God! have become an accomplished fact, and the amount of happiness which can be conferred by five shillings a week may indicate to the political student the economic conditions under which the recipients must have fought their life-struggle of threescore years and ten. If only our land legislation could have kept pace with the Pensions Act! But our measure of land reform must, alas, to some extent be regarded as a comparative failure. It has done something; in comparison with former measures of the kind it has achieved a very great deal ; but its results have hitherto fallen far short of the level demanded by reasonable enthusiasm and long delayed hopes.

Of the total number of 23,122 " approved applicants" since the Act came into operation, only 12,192 have been actually placed on the land by the County Councils in five years! Hundreds of the original applicants "dropped off " the list from sheer weariness and disgust; at the end of 1911 there were 8,548 individuals and eight associations still unsatisfied, and the number at the close of 1912 was practically the same $(8,508)$.

Much was expected from the Small Holdings Act of 1908. It was of course fairly recognized that the non-inclusion of the County Councils in the administration of the measure would 


\section{PROBLEMS OF VILLAGE LIFE}

almost certainly have prevented the Bill from becoming law, but the proviso that compulsion could be applied in the case of County Councils who failed in their duty helped to reassure those who had worked for a genuine instalment of rural reform. Such hopes have proved illusory, and local Councils have been allowed to thwart and delay the administration of the Act or openly to defy the Board of Agriculture. No county in England is better adapted for the creation of small holdings than Herefordshire. Nevertheless not a single acre was acquired last year (1912), and at present there exists an unsatisfied demand from ninety-eight applicants for 2,906 acres. Such success as has been achieved is due largely to the energy of a few County Councils. Norfolk, Somerset, Cambridge and Devon account for no less than one-fifth of all the land acquired by the sixtythree County Councils of England and Wales.

The progress officially claimed for the Small Holdings Act is to some extent illusory, for it appears that of the total number of applicants in the first five years one-fifth have been provided with land direct by private landowners, in other words, by negotiations which, however they may have been encouraged or arranged by the Board of 
Agriculture, have absolutely nothing to do with the Act and leave the small-holder entirely outside its safeguards and security.

Some interesting points arise with regard to the quantity and quality of the applicants for small holdings. In 1908, the first year of the Act's working, 23,285 men applied for land, and of this number no fewer than 10,083 were rejected as unsuitable! This wholesale refusal of nearly 50 per cent. of the applicants has not received the attention it deserves. It is repeated in the figures for 1909, for out of 3,598 fresh applicants, 1,609 were refused a place on the "approved" list. A slight improvement occurs in 1912 : nevertheless, two in five of the latest applicants were refused. On what grounds were these sweeping rejections made? Nobody would, of course, deny for a moment that some of the applicants may have been notoriously drunken, idle, or hopelessly inefficient, and as such most justifiably excluded from the benefits of the new law. But pretexts of a wholly different order have sufficed in some cases to bring about the removal of a man's name from the list. Sometimes the very natural resentment displayed by poor men against rough, inquisitorial methods of gauging the amount of their 


\section{PROBLEMS OF VILLAGE LIFE}

capital has furnished a ground for refusing to entertain an application. The great majority, however, of the refusals were no doubt based on financial reasons. The applicant might be an honest, sober, and industrious man, but if he could not produce evidence of possessing capital to the extent, say, of $£ 5$ an acre, the County Council would decline to place his name on their list. Nevertheless, the case of poor but deserving applicants was expressly provided for in the Act, which offered facilities and encouragement to County Councils willing to undertake the formation of "Land" and "Credit" Banks. These banks have succeeded admirably on the Continent, and also in Ireland. Yet not a single County Council in England appears to have made any effort to establish such a means of providing the necessary capital for the poor men whose applications have been ruthlessly rejected. It is indeed pitiable that under an Act which was intended to "colonise England" and "lighten the gloom which had settled on so many of our villages," nearly half the applicants have been summarily denied any succour, and have been driven back to the "gloom" from which the Act was meant to deliver them!

We must have a new and better Act. If 
Sir Henry Campbell-Bannerman's hopes and prophecies are to be fulfilled-if the labourer is to be given a real chance to emancipate himself from the quasi-serfdom of his miserable wages and his tied cottage-if our young men and women are to be kept in the country villages, a much stronger measure of Land Reform is needed than the Small Holdings Act of 1907. The Scottish Act has shown us the right way. In the case of any subsequent law for the extension of small holdings in England it is clear that County Councils must be deprived of the work which they refuse to perform adequately. Their duties must be taken by a Commission, presided over by some genuine reformer who will act as well as talk-and composed of men whose single purpose is to wipe off some of the long arrears of political neglect, and make the life of our English villages better worth living. 


\section{CHAPTER IX}

\section{CO-OPERATION AND CREDIT}

Every student of rural life deplores the lamentable absence of co-operation amongst our farmers and small-holders. We still refuse as a nation to treat agriculture on business lines pure and simple. Exports have been regarded as the tests of prosperity in the case of our manufactures. Our farmers export nothing; the outstanding features in their case is the ever-increasing volume of agricultural imports. France, able in normal years to feed her own people, has felt compelled to organize her agriculture against the competition of lands like the Argentine, with better climates and unexhausted soils. The use of refrigeration has given fresh impetus to the trade in imported foodstuffs. Ocean freights have become so low that frozen meat can be brought from Australia for slightly over $\frac{1}{2} \mathrm{~d}$. per lb. Despite these facts co-operative effort in rural England is either non-existent or advancing at a snail's pace. Nevertheless, 


\section{CO-OPERATION AND CREDIT 199}

since the failure of Lord Winchilsea's devoted efforts, several organizations like the "Wilts Farmers Limited," and the "East Anglian Farmers Association," have met with very considerable success, and it is to be hoped that the efforts of the State may sooner or later succeed in inducing our farmers generally to adopt the practice of co-operation on a scale worthy of our country. The main reasons for the slow growth of the movement hitherto have been the general lack of interest in agricultural matters displayed by successive Governments, the deep-seated conservatism and individualism of the farming class, and, finally, the jealous opposition of traders and middlemen.

There is a special reason at the present time for desiring to see the farmer enjoying the benefits of co-operative organization. A higher scale of labourers' wages must inevitably be demanded before long, and this added burden would be more easily borne by the farmer if he was able to effect individual economies in the purchase of his materials and the sale of his produce.

The inherent dislike of co-operation is to some extent responsible for the unfair treatment which, in the opinion of many farmers, is accorded to their goods by the railway 
companies. Far more favourable terms for transit are usually enjoyed-so it is allegedby foreigners who send us their produce than by our own farmers at home. But in answer to such complaints the railway companies point out that because the foreigners combine to send us their foodstuffs in vast bulk, charges for conveyance can be granted which are clearly impossible in the case of individual farmers in England, who obstinately hold aloof from combination and the joint dispatch of produce in mass. It is, we are told, out of the question that ten cwts. of produce should be carried at the same rate as that charged for the conveyance of fifty tons. Moreover, even on the showing of the farmers' own friends, it seems clear that in some cases not only the absence of co-operation, but the absence of good management militates against a lower scale of transit charges. Articles like cheese or bacon when sent from Denmark or America are so strongly packed that a truck can be filled with the cases. English goods of this character are sometimes dispatched to market in such fragile boxes that not more than one or, at most, two layers can be placed on the floor of a truck.

Closely allied with co-operation is credit. Agriculture in England suffers from the 
absence of adequate capital in the shape of ready money available for special and temporary necessities. The writer, in the course of a meeting held to explain the Small Holdings Act, touched upon the question of the capital required by an applicant, and was met by a cry from several labourers present: "Oh, that's all right, sir, many of us have got quite as much capital as the farmers." Several of the farm hands in this parish had managed by almost phenomenal thrift to save from £50 to $£ 100$; and they were perfectly right in suggesting that few farmers had, proportionately to their responsibilities, an equal amount of ready cash. Most County Councils demand that a Small Holdings applicant shall possess $£ 5$ per acre of the land required. How many farmers taking up a farm of 200 acres could lay their hands on $£ 1000$ ?

It is strange that while capital is freely forthcoming for other branches of industry, our greatest national industry of agriculture has no adequate credit at its command. If a British farmer requires a loan for the special needs or development of his farm he is too frequently driven, in the absence of mortgage possibilities, to the exorbitant methods of the private money-lender or the almost equally unsatisfactory help of the persons who pur- 


\section{PROBLEMS OF VILLAGE LIFE}

chase his produce. When Mr. Henry Wolff proposed some years ago to establish a scheme of co-operative supply and credit for the farmers of Sussex he was informed by one of the most experienced farmers in the county - "You will never get these men to join you, they are every one of them on their dealers' books and cannot get off." The almost invincible individualism of the English farmer and curious mistrust of his neighbours which he shares with his labourers renders the establishment of agricultural banks on Continental lines a difficult task. The trader glories in his credit. The larger is his credit, the higher is his repute. The farmer looks upon the use of credit almost as a disgrace. In other words the farmer's finance is thoroughly unbusinesslike. He rarely borrows until it is too late, i.e., not in order to obviate loss, but after the loss has taken place.

While the farmer finds it difficult to secure adequate credit facilities, the case of the small-holder is even worse. "The poor man," says an Italian writer, Guistino Fortunato, " obtains no credit because he is poor, and he remains poor because he has no credit." Credit in England is still a virtual monopoly of the well-to-do classes. To those who have it it is given, and to these only. The County 


\section{CO-OPERATION AND CREDIT 203}

Councils were assigned the duty of encouraging the establishment of credit banks for smallholders. After five years' working of the Act not a single bank of the kind has been established in England by the agency of the Councils.

In her general neglect of agricultural credit Great Britain stands almost alone in Europe. Even backward countries like Turkey possess a system of agricultural banks, the advances of which to Albanian farmers have been unjustly called in by the Servian conquerors for their own use. The famous Raffeissen system of credit banks based on co-operation and mutual responsibility has since 1849 been widely extended in Germany, Austria, Italy, France, Poland, Roumania, etc. In Germany alone there are 1,700 co-operative credit banks. A number of agriculturists combine to form the bank, and the security demanded for a loan to any member is twofold, the borrower must be a man of trustworthy character and his enterprise must be of such a sound character that there is a good prospect of his success and his ability to repay the loan. It may be thought that such abstract security as this is unfitted to form the basis of a business undertaking : but any fears on this score are completely dissipated by the facts of experience. 


\section{PROBLEMS OF VILLAGE LIFE}

The banks have proved a signal success, a reasonable return on the small capital involved is secured, and a defaulter is a very rare phenomenon.

There is surely no valid $a$ priori argument against the benefits of these banks amongst ourselves. If sound character is found to be the best possible security on the Continent it can safely be relied on in England. It would be humiliating to suppose that farmers and peasants in other countries can be trusted, while our own fellow-citizens cannot. Nor, indeed, can this suspicion hold the field for a moment in view of what has actually taken place in Ireland, where co-operative credit banks are working with excellent results; in view, too, of the indubitable integrity of our English small-holders proved by the experience of the Commissioners and County Councils. Small as the progress of co-operative credit in Great Britain is up to the date of writing, the record of the forty-five societies already established in England and Wales is encouraging. But when one reflects that in Servia there were, in 1906, including local branches, no less than 750 of these banks, our national backwardness in this useful and almost essential enterprize is certainly remarkable. We can only hope that the efforts of our Board 


\section{CO-OPERATION AND CREDIT 205}

of Agriculture will be successful in undermining the general reluctance on the part of our rural population to accept the principle of personal credit and unlimited liability.

It is probable that two different kinds of banks may be required in rural districts : an agricultural bank, more properly so called, for the farmers, depending on the assistance rendered by existing Joint Stock banks in the neighbourhood, and banks on Raffeissen lines for the benefit of the labourer and small-holder. In every case it is to be hoped that such institutions large and small will not be encouraged to rely too much on the personal support of neighbours, however well disposed they may be. No taint of private patronage or "charity" should be attached to any genuine system of "people's banks;" our countryside has suffered too much already from these influences, and though individualism dies hard in rural England it must obviously yield before the advance of the collectivist spirit which more fully day by day inspires the life of our towns and cities. 


\section{CHAPTER $\mathrm{X}$}

SOME OTHER REMEDIES

\section{1.-Protection}

For many years before Mr. Chamberlain's historic crusade of 1903 , the restoration of protective duties on agricultural produce imported into Great Britain had been proposed by the advocates of "Fair Trade" as a sovereign remedy for the evils of British agriculture. In more recent years public attention has been called to this policy through a series of general elections, and there can be little doubt that sooner or later when a Conservative majority is placed in power by the electorate some attempt will be made to impose certain taxes on the corn, meat and dairy produce which reach our shores from foreign and, perhaps, colonial ports. ${ }^{1}$

1 The Tariff Reform Commission proposes (apart from duties on manufactured imports) 2s. a quarter on foreign and Is. on colonial wheat; " equivalent duties " on other grain, both foreign and colonial; 1s. $3 \mathrm{~d}$. a cwt. on foreign flour and meal, an average 5 per cent. on meat (bacon not 


\section{SOME OTHER REMEDIES 207}

It may therefore be fairly held that the imposition of tariffs on agricultural imports is at present regarded by a considerable minority of our British electors as a measure of real value to the country in general and our rural districts in particular. However fantastic this opinion may appear to Free Traders the stern fact remains that it is well within the bounds of probability that some future general election may result in a Parliamentary majority pledged to a policy of food taxes, and able to pass protective legislation rapidly through the favourable co-operation of the House of Lords.

It is necessary therefore to include the policy of Tariff Reform amongst the serious proposals which have been made for benefiting and improving the conditions of rural life in England, though within the limits of this little volume this quaestio vexata can receive only the most cursory and general treatment.

It is as futile for the Tariff Reformer to deny that taxes on meat and corn are "food taxes" designed to raise the price of these articles in the home market as it would be for the Free Trader to say that duties on

excepted), and 5 per cent. to 10 per cent. ad valorem on other agricultural produce (the "preference" on all to be arranged by negotiations with the Colonies). 


\section{PROBLEMS OF VILLAGE LIFE}

such commodities will benefit nobody at all. To begin with it is quite certain that Tariff Reform would be of real advantage to our landowners. The ordinary experience of history shows us that in the days preceding the abolition of duties on corn, our landed proprietors reached a very high level of prosperity, and in fact the great majority of our imposing country "Halls" were built at a period when the price of corn was maintained by high protective duties. Even since the advent of Free Trade, while landowners have in numerous cases shown generous consideration to their tenants in years of depression, rents have undoubtedly been raised when agricultural prices improved. It is obvious therefore that the general rise in the price of wheat and other produce which would result from the new duties would be the signal for a general rise also in the farmer's rent.

The support of Tariff Reform therefore by our landowners is quite natural and normal. There is nothing worse or better in a vote the squire records for a protectionist party than in his labourer's vote for an old-age pension party, if both electors are thinking solely and simply of their own individual pockets. A very brief acquaintance with practical politics proves that large numbers of our voters in all 
classes are aetuated simply and solely by "bread and butter" eonsiderations. Where the sincere Free Trader parts company from the equally sineere Tariff Reformer is in his conviction that the enhaneed prosperity from Protective duties of the few thousands who own and farm the rural land of England is manifestly inconsistent with the welfare of the many millions in town and country who are consumers and not produeers of eorn and meat.

It is believed by the great majority of British farmers that import duties on corn, meat and dairy produee will, by raising the price of these goods, inerease their own incomes. In short, the words "Tariff Reform will benefit agrieulture," mean that the position of both landowners and farmers will be bettered by the new system. There cannot under normal conditions be two widely divergent prices for the same article in the same market, and the price of all farm produce eonsumed by the population will be more or less appreciably raised. "Wheat," we are told, "eannot be grown profitably at present prices; give us Tariff Reform and there will be no more conversion of arable into grass land." It is therefore disingenuous on the part of any contro- 
versialist to conceal the patent fact that the general purpose of farmers who support Tariff Reform is to secure better prices for the goods they sell.

We might, therefore, unreservedly associate farmers with landowners as certain gainers from a system of import duties, were it not for the following facts. As mentioned above, any considerable advance in the price of farm produce tends sooner or later to a rise in the tenants' rent. Again, the farmer must not forget that he is not only a seller of agricultural produce but also a buyer. Vast quantities of barley, oilcake and other fecding-stuffs are purchased by the tenant-farmer, and the increased cost of these must be set against the enhanced revenues from the sale of his own produce. On this debit side, too, must be placed the augmented cost of machinery, saddlery, hardware, clothing, etc., which must necessarily ensue from the average 10 per cent. suggested as a tax on manufactured goods. It is difficult in any case to see how our great and increasing industry of dairy farming could be benefited by protective duties, for the milk trade, of course, does not suffer from the competition of foreign imports.

It may, therefore, be doubted whether the actual gains of the farmer from Tariff Reform 
would be as great as is commonly assumed. It seems probable that if he can resist the landlord's very natural demand for higher rent he would in many cases derive some more or less substantial benefit from the new fiscal system. Arguments, however, from the analogy of foreign farmers are not altogether reliable in this connection. Enormous influence is, it is true, exerted in Europe by the "agrarian parties" in favour of food tariffs, but we are apt to lose sight of the vital fact that on the Continent the vast majority of farmers arc their own landlords, and the extra profits flowing from tariffs remain in their own pockets.

In any case the only absolute security for increased gains by farmers under Tariff Reform would be provided by the establishment of Courts which would furnish some check on the landlords' demands for increased rent. Such Rent Courts find a precedent in Ireland, and, quite apart from the Free Trade controversy, are eminently desirable as long as the land of England remains in private hands.

But even if the large majority of our farmers succeeded in improving their incomes through Protection, the Free Trader, whatever may be his personal sympathies with a class of men 


\section{PROBLEMS OF VILLAGE LIFE}

whose industry is exposed to extraordinary vicissitudes of depression and prosperity, cannot withdraw his opposition to a policy of Protection. Despite the fact that agriculture is our greatest industry, the landlords and farmers of the country form numerically a very small class of the population, and even in rural districts are vastly outnumbered by the agricultural labourers and other workers who live in our villages and hamlets.

To take the latter class first. Would the ordinary farm labourer be better off under a fiscal system which, inter alia, raised the price of agricultural produce ? The ordinary reply of the more thoughtful exponents of Tariff Reform would be that (a) the increased cost of bread, meat, butter and so on would bc very small and (b) that the increased prosperity of the farmer would mean increased wages for the farm hand. But there is absolutely no guarantee that low duties would not be raised. The expericnce of other countries points strongly in this direction, and in our own midst influcntial agriculturists, even before the establishment of a 2/-duty on wheat, are declaring that nothing under $10 /-$ or $15 /-$ a quarter would be of any practical use to the farmer ! And what conceivable guarantee can exist for higher wages under a system of 


\section{SOME OTHER REMEDIES}

protective duties ? The promises held out are doubtless quite sincere in many cases. Mr. George Terrell, M.P., has recently declared that the "wages of the agricultural labourer could not continue" at their present figure and that the one and only remedy for this lay in the adoption of Tariff Reform. The farmer, according to Mr. Terrell, would share in the increased prosperity, and so be enabled to pay his men better. This optimism has little foundation. There is no necessary connection between higher prices and higher wages unless indeed the workers are strongly enough combined to enforce their claims, and at present our agricultural labourers are singularly helpless from the very fact of their almost complete lack of organized union. "Who," asked Lord Goschen in the House of Lords, " will take the responsibility of saying, "let us put a tax on food, and I will guarantee that your wages shall be raised'? I say that this is a tremendous responsibility, and one which I, for one, would be most reluctant to undertake." Wages, of course, have little to do with the question of import duties. Depending as they do very largely on the laws of supply and demand on the one hand and the power of labour combinations on the other, it is childish to point to the higher 


\section{PROBLEMS OF VILLAGE LIFE}

wages of comparatively new and "unfilled" countries like the United States and Canada and New Zealand as proof positive that protective duties involve a better return for labour. One might just as well argue that the heavy tariffs existing in Russia or Italy are the direct cause of the miserably poor wages which prevail in those countries. Moreover the memory of our own Corn Laws has not vanished from the villages of England, and the rustic politician points to the fact that when wheat was selling at $60 /-$ a quarter or even more, his grandfather's wages stood at 7/- to 8/- a week. Between 1820 and 1837 no fewer than five Government Enquiries took place on the subject of agricultural distress. Farmers, we are told, were crushed beneath burdensome rents and labourers' wages were appallingly low. "The condition of the farmer," said Mr. Chamberlain, "was never so hopeless and the state of the labourer never so abject as when corn was kept up at a high value by a prohibitive protective duty - when it was $64 /$ - or even rose to $120 /-$ a quarter." It is of course said, and honestly said, that no such treatment of British labour would be possible in the twentieth century. This dictum would be more convincing were it a fact that any strong union 
of agricultural labourers existed which could support its just claims to an adequate share in the hypothetical benefits of Tariff Reform. No such combined effort on any adequate scale is to be found at present, and the general attitude of our farmers is hostile to the growth of Trades Unionism among their farm hands. I have often heard labourers asking a Tariff Reform optimist why if higher prices mean better wages, not a single farthing was added to their weekly pittance when in 1909-10 wheat rose to $45 /-$ a quarter and the loaf to $6 \frac{1}{2} \mathrm{~d}$.

In any case the reversal of our existing system of free food would be determined, not by the agricultural population but by the industrial voters in the towns. The adherents of a Tariff Reform policy have been driven by experience to realise the immense difficulty of persuading the average urban elector to submit to any imposts, however slight, on his bread and meat. The artisan may naturally ask why the overwhelming majority of our working men and women should fasten upon themselves an artificial increase in the cost of living in order to swell the incomes of squires and farmers in the rural districts. As it is, he provides the extra taxation required to make good half the farmers' rates and he may 


\section{PROBLEMS OF VILLAGE LIFE}

sooner or later be invited to sanction the use of imperial taxation, 75 per cent. of which accrues from towns, in order to provide better accommodation than his own for distant villagers in whom he has no personal interest. To such a man, the additional burden of more costly food would surely appear as mere quixotic altruism. He is also quite unmoved by the fervent appeals of great landowners who demand from the urban populations "willing sacrifices" for the benefit of flourishing colonies, whose people are, man for man, far better off than ourselves.

A more subtle reason frequently underlies the opposition shown by urban employers to protective duties on food-stuffs. Starting with the axiom that low wages are essential for commercial success, they realise that, in the event of an artificial raising of the price of food commodities, an irresistible demand will be made by organized Labour for a corresponding increase of wages-a serious handicap on industry. Food taxes may, it is true, be endured by the industrial populations of European countries whose citizenship is still incomplete, or of new countries where the general prosperity is so great that the burden of higher food prices is comparatively less noticeable. But the fundamental antagonism 


\section{SOME OTHER REMEDIES}

is still there. "Voilà le terrible!" cries the farmer Houdequin, in La Terre, "D'un côté nous autres les paysans, qui avons besoin de vendre nos grains à un prix remunerateur. De l'autre, l'industrie, qui pousse â la baisse, pour diminuer les salaires. C'est la guerre acharnée . . ça ne peut pas finir. .

Si le paysan vend bien son blé l'ouvrier meurt de faim; si l'ouvrier mange, c'est le paysan qui crêve. . . . Alors, quoi ? Je ne sais pas, devorons-nous les uns les autres!" The urban population of Germany are only prevented from sweeping away protective food-taxes by the existing distribution of Parliamentary constituencies, which assigns a grotesquely unfair share of political power to the agrarian districts. And it is significant that the great and wealthy United States is ridding herself of many protective imposts on food as well as manufactured articles, at a moment when our English Tariff Reformers are struggling to reimpose similar duties, long since discarded!

\section{2.-Trades Unionism}

Amongst the regularly employed workmen in the kingdom the agricultural labourer has been for centuries by common consent the most neglected. Parliamentary help is rarely 


\section{PROBLEMS OF VILLAGE LIFE}

forthcoming in its fulness for those who cannot help themselves, and the agricultural labourer has for generations been more or less inarticulate.

For the most part he does not generalise from his experience even in private and individual conversation. Still less does he put into words, or urge upon the public by way of agitation, his views or his desires. Generations of dependence have left him timid and taciturn. His instinct of combination is weak. And, except for the one tremendous effort of the early seventies which is associated with the name of Joseph Arch, he has never on any large scale organized himself into any society or union designed to represent his class. Thus even his vote has been of comparatively little use to him. This inability to organize is the main cause of his weakness. Standing alone, accepting no help from his fellows, and sharing in his turn no feeling of solidarity with them, he is at the mercy of every passing influence which is brought to bear on him. The landowners, who loom largest of all in his imagination, lull his discontent and sap his independence by dispensing material comforts, and send him to the polling stations to support their nominees for Parish, District or County Council, or for Parliament. In too many 


\section{SOME OTHER REMEDIES}

cases the ministers of religion draw him to church or chapel, if at all, by means of social and other attractions. Shopkeepers and publicans get him into their power by the use of credit. Farmers denounce his inefficiency, while they dread his disappearance. He, for his part, can make little or no attempt to stand up against the influences that are brought to bear upon him from all sides.

The labourer's individualism, his failure to combine with his fellows for the common good, is an almost inevitable outcome of his age-long environment. The broad vista of the open fields, the long distances, the solitary work, the sense of lonely remoteness when he is "left to darkness and himself" - all such influences tend to soothe discontent and deaden suffering. A sense of helplessness is engendered by the social surroundings of the village and his crippling povery; and so he endures his lot with that amazing patience which is his mental heritage from centuries of neglect and oppression.

The spirit of combination which animated the labourer of the fourteenth and fifteenth centuries was gradually crushed out by the enactment and re-enactment of prohibitive laws, and not even the triumphant advance of Trades Unionism in other departments of 


\section{PROBLEMS OF VILLAGE LIFE}

industrial life has availed to stir the energies of our poor village folk. At a time like the present when on every side the sounds of healthy discontent are surging around us with immense benefit to the national well-being of our workers, the voice of the agricultural labourer is almost silent; nevertheless the ancient fires, rekindled in the Swing Riots and the brief but wonderful success of Joseph Arch, are not wholly extinguished.

The difficulties of effective combination in rural districts are no doubt serious ; and they have been to some extent accentuated by the compulsory contributions of the excellent Insurance Act, for no Union can be maintained under a weekly contribution of $2 \mathrm{~d}$. Nevertheless, a new organization is slowly rising from the ashes of Joseph Arch's Union, and will make itself felt in the coming years. And why not? Everywhere else to-day we find a spirit of unrest amongst the workers of England, on the whole restrained and dignified, yet definite and determined. The strikes of seamen, railwaymen, miners, dockers, tailors, and so on, are all outward and visible signs of that new spirit which must, and ought to follow the better education and wider enfranchisement of a nation's workers. Lawyers, doctors, and parsons have long ago 
fixed their minimum fees, nor is anybody who gcts up at a Church Congress and pleads for $£ 300$ a year as the reasonable income of a beneficed clergyman described in the Guardian as an "agitator." In short, masters fix the price of their commodities, and the workers will fix the price of their labour. Now, then, is the acceptable time to extend helping hands to the poor toilers in our fields. Who will deny the justice of their cause?

It is among the sturdy labourcrs of Norfolk, a race of men famous in English history for their love of freedom, that the old spirit of combination has been chiefly preserved. The centre of the new movement toward Trades Unionism is the hamlet of Hempton, near Fakenham. Here in a single room two men are working daily for the cause, Mr. George Edwards, C.C., and Mr. H. R. Walker, the two secretaries of the National Agricultural Labourers' and Rural Workers' Union. The former, who began life once as a labourer at six years of age, was a colleague of Joseph Arch in the great village movement of the seventies ; and it is largely by his unselfish energy and enthusiasm that the dying embers of Unionism have been preserved from extinction. The amount of work accomplished by these two sccretaries is amazingly great. Their labours 
do not end with the close of office hours, for they frequently, after a hasty meal, hurry away on their bicycles to a village green in some remote parish. Not even Sunday is free, for camp meetings at 2.30 and 6 are held regularly on that day in the summer months. The Union of 1872 . was inspired by that religious spirit which has through the centuries formed a feature of every attempt on the part of our English peasants to secure redress for their ills. On the other hand, the revived Union has learned from the story of Joseph Arch's success and failure the need for caution and financial solvency.

The general objects of this rural Union, far too little known to the public, have been summarized as follows :-

1. To improve the social and moral conditions of its members.

2. To establish a central fund for the purpose of securing proper representation in the Imperial Parliament and on all local authorities and a better distribution of land, by assisting to provide allotments, small holdings, improved housing accommodation and better conditions of living.

3. To secure proper legal advice when necessary and to shield members from injustice. 
4. To relieve members out of work through disputes and lock-outs when sanctioned by the Executive Committee or the General Council of the Union.

The membership of the revived Union has steadily increased, and most urgent appeals for the establishment of fresh branches have been received from Oxfordshire, Wiltshire, Northamptonshire and other counties, appeals which cannot be met at present from lack of means. The branches, it is true, when once organized, are self-supporting, but for the necessary expenses of organization it is unreasonable to draw on the funds accumulated from the scanty earnings of the existing members. I have described the constitution of the new Union in some detail, because it is scarcely known to the general public and still more because it promises to become a very real and beneficent factor in the regeneration of rural life. The members of the Union are recruited from the ranks of the best and steadiest labourers, and experienced agriculturists have declared that they preferred to have Union men on their farms because they could usually rely on their sobriety and industry. Until the Union secures a material increase in its numbers any attempt at a strike will always be attended with considerable 
risk. The numerical weakness of the new Union has hitherto prevented any widespread recognition of its existence and purpose, while the facile provision of " free labourers" forms a serious menace to the success of any local effort to secure better terms by force. It is well known that a number of "blackleg" labourers are "retained" by a farmers" association in order to be moved quickly to the scene of a strike or lock-out, and it was precisely the presence of these hired outsiders from Cambridgeshire which brought about the failure of a strike at St. Faith's in Norfolk in 1911.

Nevertheless it seems clear that in any widely-developed and well-organized strike of our village labourers the general sympathy of the public would be accorded to the men, and there can be little doubt that if the numbers and resources of the Union largely increase and the demands for better conditions of life are not secured by legislation or concession the prevailing discontent of the agricultural labourers will sooner or later bring about a general strike at harvest time, which would almost inevitably result in the defeat of the employers. 


\section{3.-Rating and Taxation of Land Values}

A new remedy for rural evils has lately been pushed to the front. The rating and taxation of land values has descended like some deus ex machina to dispel the mists which have so long settled on rural prosperity. One gathers from the speeches of its exponents that the rating of land on its unimproved value is to benefit the labourer, the small holder, the farmer, and even the landlord simultaneously! It is, one fears, too good to be true, unless indeed it be taken for granted that in some vague and benevolent fashion the hypothetical millions to be raised from urban land values are to be partly applied to the relief of rural burdens. Such a doctrine might be rendered popular in the country districts, but the British farmer, who enjoys the unique privilege of having half his rates paid for him, must indeed be an optimist if he believes that the town populations will consent to furnish any further help on these lines.

When you ask our "land-taxers" about the precise benefits which will accrue to a rural parish from their financial proposals, you are usually met with such phrases as "land will be forced into the market," "land at present neglected in the intercsts of sport or pleasure 


\section{PROBLEMS OF VILLAGE LIFE}

will be put to its best use," "owners will be compelled by heavier rates to sell their estates, and small holders will thus secure the land they desire." Those of us who want to get tangible and definite blessings-more money in the labourer's hand on Friday night, a decent cottage for himself and his family, a fair rent for the farmers, public ownership of landwe are weary of phrases largely based on misleading analogies from British Colonies, and to a large extent put forward by persons possessing little real knowledge of English village life. One would imagine from some " singletax" speeches that everybody in the country is clamouring for a small holding, and that a 3d. rate on the bare value of a pheasant covert will transform it into allotments.

Nobody questions the sincerity of the "Land Values" politician, or his ability in some cases to rouse the enthusiasm of urban ratepayers; nor are we concerned with the policy as applied to urban site values. Nor, again, are we discussing the goodness or badness of the existing Budget taxes on Land Values. The present impost of $\frac{1}{2} \mathrm{~d}$. in the $\mathfrak{E}$ on undeveloped land may appear to some as taxation pour rire, and no convincing reason may exist for leaving four-fifths of the increment value in private pockets. The only 
question for the moment however is whether a method which may be of advantage to urban ratepayers will do us any good in the rural parishes. It is not possible to enter here into all the detailed arguments for and against the position of the taxers and raters of land values. But there is one basic fact which must not be overlooked. The Census of Production for 1908, the last agricultural return we possess, makes it quite evident that the amount of unused land in the country is nothing like so large as might be assumed from the normal "land values" speech. The land actually used for agricultural purposes appears to be $47,795,223$ acres. There remain, therefore, in the whole of Great Britain some 9,000,000 acres of non-agricultural land. But as this includes all land built upon, railways, lakes and rivers, and holdings of one acre and less, it will be seen that the residuum of land unused for any productive purpose is not a very large one. As far as agriculture is concerned, some of the 12,800,000 acres of mountain and heath now devoted to rough grazing with a present output of 10/- to $12 /-$ per acre, and some, too, of the 2,781,963 acres of woodland with an output of 6/- might, under the pressure of heavier rates, be placed upon the market or rendered more productive; but this antici- 


\section{PROBLEMS OF VILLAGE LIFE}

pation is not enough to justify wild prophecies of cheaper land, extensive house-building, and better wages.

As regards the arithmetic of "land values" rating as applied to country districts, it is difficult to obtain any precise or authoritative statements about the actual amount of the proposed rate or tax. It may, of course, be urged that until the value of the land is ascertained by the Government Commissioner definite figures as to the amount of the rate are impossible. But an estimate of site value is not so difficult a matter as some would have us believe, and the generally accepted total of 3,000 millions as the site value of the land in the United Kingdom is, perhaps, not very wide of the mark. If this value is to provide the "sole basis" for rating (as stated in a resolution passed at a recent Land Values Conference) a rate of $8 \mathrm{~d}$. in the $\mathfrak{E}$ is required to meet the 100 millions represented by existing local rates plus Government grants in aid. Sometimes a lower rate of $3 \mathrm{~d}$. is suggested, at other times a penny rate.

Some examples are here given of the manner in which such rating would operate in the case of agricultural land, the instances being taken from a number of bona-fide returns. 


\section{SOME OTHER REMEDIES}

\begin{tabular}{|c|c|c|c|c|c|c|}
\hline $\begin{array}{l}\text { 范 } \\
\text { د }\end{array}$ & \multicolumn{6}{|c|}{ 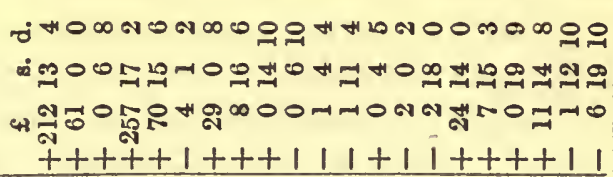 } \\
\hline 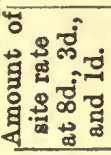 & 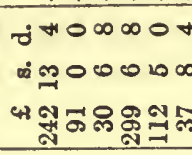 & $\begin{array}{l}\infty \\
\infty \\
\infty \\
\infty\end{array}$ & $\begin{array}{l}09 \\
0 \\
0\end{array}$ & $\begin{array}{ll}* \infty \\
400\end{array}$ & Nor & \\
\hline 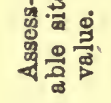 & * & 용 & क्ञ & $\stackrel{s}{\circ}$ & $\stackrel{m}{\infty}$ & 광 \\
\hline 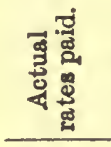 & 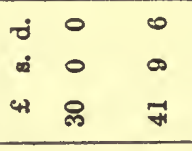 & $\begin{array}{l}\dot{0} \\
\vdots \\
\infty\end{array}$ & $\begin{array}{l}\stackrel{9}{9} \\
\pm \\
-1\end{array}$ & $\begin{array}{l}ت \\
0 \\
\infty\end{array}$ & $\begin{array}{l}0 \\
\infty \\
\text { o }\end{array}$ & $\stackrel{m}{\pi}$ \\
\hline 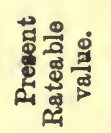 & $\begin{array}{lll}\forall & 0 & 0 \\
1 & 0 & 0 \\
4 & 8 & 9\end{array}$ & $\begin{array}{l}+1 \\
0 \\
+1\end{array}$ & $\begin{array}{l}0 \\
0 \\
0\end{array}$ & $\begin{array}{l}0 \\
\stackrel{0}{9} \\
\dddot{9}\end{array}$ & $\begin{array}{l}\text { a } \\
0 \\
0\end{array}$ & $\begin{array}{l}0 \\
0 \\
0\end{array}$ \\
\hline 迎 & 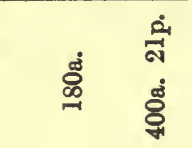 & 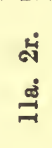 & $\begin{array}{l}\dot{4} \\
\text { هั }\end{array}$ & : & की & 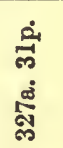 \\
\hline 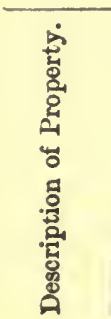 & 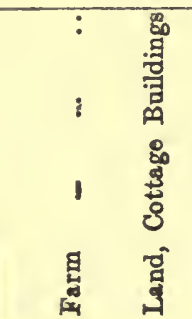 & 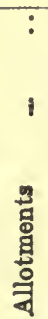 & 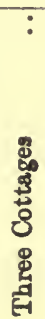 & 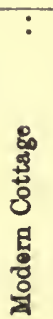 & 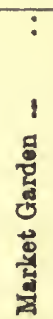 & 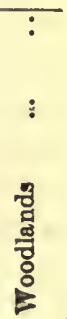 \\
\hline
\end{tabular}




\section{PROBLEMS OF VILLAGE LIFE}

Is this, then, the golden remedy for low wages and bad houses? Who is going to pay the vastly increased imposts on rural farmlands? If the farmer is to shoulder the new burdens, how can he afford the better wages urgently needed for his labourers? If the landlords pay the rates without foisting them upon the tenant (a most improbable contingency), how are they to accept less rent, which in many cases they must do if the labourers are to have decent wages? And what has happened to the coverts? Will any man who can afford to hunt or shoot shut up his woods because of an increased tax of $£ 11$ 14s. 8d. on 327 acres-about the cost of rearing a couple of dozen pheasants ? If on the other hand, the $3 \mathrm{~d}$. or $1 \mathrm{~d}$. rates are levied the sporting landlord in the above instance actually pays less under the new than under the old system-a strange reductio ad absurdum! Notice in any case that the burdens on the farms, market gardens, and allotments are increased. No, our villages need something better, more definite, more tangible than any mere alteration in our rating system. The labourers are tired of waiting, and they are not going to allow practical reforms to be side-tracked by such nebulous remedies as the "forcing of the land 


\section{SOME OTHER REMEDIES}

into the market " and hypothetical remissions of existing taxation. Railway men and miners were not diverted from their successful pursuit of better wages and better conditions by any shifting visions of a land-tax millennium. "Cut your cackle and give us more wages-it's the rivets we're after," says a working man in Seems So. The members of the Agricultural Labourers Union know what they nced. They demand a living wage and a decent cottage, and greater facility in the acquisition of small holdings at a reasonable rent. They do not include in their programme the rating of "unimproved land" values in rural districts.

\section{4.-Land Nationalization}

The most drastic remedy offered for rural ills is that of Land Nationalization. This proposal has received the stamp of approval not only from professed Socialists but also from a considerable body of our more advanced Radicals both inside and outside the House of Commons. The Land Nationalizer will argue that his policy alone is really adequate to cope with the evil conditions of agricultural England. According to him the entire system of private land-ownership embodies so many defects that measures such as Rent Courts 


\section{PROBLEMS OF VILLAGE LIFE}

or Small Holdings Acts can merely serve as palliatives. The unhealthy growth of greed, monopoly and social arrogance on the one side, and on the other dependence and poverty in varying degrees, is so deeply rooted in the past that complete eradication is necessary. The Squire's rule, which individual caprice could always employ as an engine of cruelty and oppression, has from the increased appropriation of the soil by wealthy outsiders gradually lost any good influences it ever possessed. The whole system of individual ownership in the country's soil must be destroyed.

The two main methods suggested for securing State ownership of the soil are (a) the direct purchase of estates at a fair and reasonable price, or (b) the conversion of privately-owned land into State property by means of a gradually increasing tax, up to

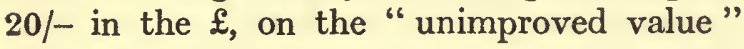
of the land.

The second of these proposals has already been noticed in dealing with the rating of land values. As regards the first of them, which in general appeals to the national sense of fair play and has some kind of precedent in the great Conservative measure of Irish Land-Purchase, the actual price of the 


\section{SOME OTHER REMEDIES}

State-acquired land may be either paid in ordinary and perpetual Government bonds, or in annuities terminable after a certain period. In the former case it has been doubted whether on the whole the benefit secured to the community would be worth the trouble and irritation occasioned by its acquisition. In other words, could the State make the land pay more than sufficient to meet the payment of interest on its land-bonds ? To nationalize land, minerals or railways in the early days of a young country is an obvious and lucrative policy, but the case assumes a very different complexion when a similar attempt is made in the case of a country like Great Britain, where vast enterprises and resources have for many generations been permitted to exist as the property of individual citizens. Nevertheless it may be the case that even under the liability of providing a fair return for vested interests the public ownership of an English soil would well repay the bold statesmanship which succeeded in carrying such a policy to a successful issue. The economic waste of our agricultural resources, which at present strikes every thoughtful foreigner, would necessarily be impossible under State ownership directly controlled by public opinion. No one can rejoice more sincerely than the present writer 


\section{PROBLEMS OF VILLAGE LIFE}

in the pleasures of shooting or fishing, but every sportsman must acknowledge that firstclass sport and scientific farming are not easily compatible, and that no progressive nation can permanently permit the best and most complete use of the nation's land to be subordinated to the interests of a handful of the population. Scientific methods, therefore, and the cultivation of vast tracts of land which are at present partly or wholly neglected for the benefit of sportsmen would without doubt increase the output of our fertile soil, and a substantial margin of profit would accrue from the national management of the nation's acres. In any case the entire increment in the value of English land which, apart from any vast and unexpected catastrophe in the national welfare, is certain to continue, would fall into the national coffers. The difference between the acquisition of the whole increment value and that of one-fifth as at present would be so vast that here again it would appear that the nationalization of the land by direct purchase would pay well on a strictly business footing. ${ }^{1}$ Such a result

1 The Official Valuation of the land now proceeding (1912) will provide a just basis for national purchase. The increment in the value of our land is a constant factor in our history : from 1692 to 1884 the value of our 


\section{SOME OTHER REMEDIES}

would, of course, be more certainly and speedily brought about if payment were made to the dispossessed landowner by annuities, which would automatically cease after, say, the lapse of a century. The opposition to this latter proposal would be diminished from the fact that it is difficult to feel much personal interest in the future of invisible and problematic great-grandchildren; but this argument cuts both ways, for the taxpayer of to-day may equally argue that it is unfair that he should burden himself with the payment of annuities which will bestow the freehold of the English land on unborn generations in the far-off future. Even the mediæval benefactors and founders of our ancient colleges and almshouses were providing for their contemporaries, nor was their generosity chilled by the prospect of a century's postponement of any realized benefit.

It may, however, be urged against those who advocate purchase by terminable annuities that even if the confiscation is postponed in this case it nevertheless takes place. How-

land increased eighteen-fold; between 1842 and 1881 it doubled itself. This estimate covers rural as well as urban values; if we take the latter alone the extent of the increment is still more striking. 
ever unjustifiable may have been the method by which private ownership was originally established it is nowadays a grotesquely unfair thing to draw a sharp line of demarcation between landed and other property, and to declare or insinuate that the present owners of land have little moral right to it. No fair analogue exists between the tied-house property of brewers and the land possessed by men whose legal title to it has never been questioned. The Drink Traffic is admittedly one of serious menace to the national welfare which must be controlled in the public interest, nor had the claim of the brewers to a freehold in the State-granted licences ever been legally admitted until the Act of 1904 .

The proposal therefore to grant a compensation time-limit of fourteen or twenty-one years to the Trade cannot be regarded as a parallel to a precedent for the cessation of land annuities after a period of 70-100 years. If however the nation saw fit to reject the idea of terminable annuities, the entire land of Great Britain could be secured for the State by the straightforward issue of land bonds bearing interest at 4 per cent. on the selling price of the land acquired. A clear and assured 4 per cent. would be welcome to most landlords, especially those who own rural 
acres. The interest on these securities would be amply met by the increment on land values and the rent payable to the State by the tenant. And further a systematic redemption at par would, it is calculated, extinguish the land bond altogether in sixty-seven years, thus leaving the State not only with a considerable and increasing balance to the good each year, which could be used for the reduction of existing taxes or other national objects, but would hand over to our successors the entire possession of their country's land to be used for their country's good.

The overwhelming advantages of public landownership may be summarized as follows. Land would be accessible to all suitable applicants apart from all question of the personal favouritism of individual landlords. The State would have no greater interest in the political or religious views of its tenant-farmers than in those of its policemen or postmen. Full security of tenure would be enjoyed and public opinion would soon demand not only decent wages for our labourer but Fair Rent Courts to determine that the farmer should receive a reasonable and adequate return for his outlay and industry. Public opinion would further insist that the national land should be put to the best purposes, and no 


\section{PROBLEMS OF VILLAGE LIFE ,}

land would, as now to so large an extent, be unreasonably withheld from use, with the speculative object of subsequently securing a much higher price. Housing on a large scale would be infinitely more feasible if the populations of our towns themselves possessed the required sites for more and better houses.

For the same reason schemes of afforestation and land reclamation could be carried through without any hindrance from those which at present hamper such enterprise. Finally the large reserves increasing year by year would sooner or later be adequate not only to pay interest and redeem bonds but to be applied to the reduction of existing imposts or to fresh schemes of public utility.

There is of course one strong a priori argument which can be alleged against all schemes of land-nationalization. The national ownership of the means of production and distribution is in its essence a Socialist proposal, and as such vigorously opposed by no inconsiderable section of the public. So carefully has this antipathy to Socialism been fostered from various motives, good and bad, that the mere description of any measure by the term "Socialistic" is apparently enough to damn it altogether in the eyes of many Englishmen. It is simply amazing that so large a section of our 
fellow-countrymen should be quite ignorant of the meaning of current political terms. I well remember a group of educated men and women laughing heartily at a definition of a "Protestant" given by a Spanish peasant as a man who " shut himself up in a room with a Crucifix and flogged it." But there is less excuse for the current failure on the part of well-to-do men and women in our clubs and drawing-rooms to even understand the elementary meaning of such a political theory as Socialism.

Persons who protest against land-nationalization on the grounds that it is novel and "Socialistic," seem oblivious to the fact that even at present and through the agency of successive Governments of both parties they are living to a large extent in a Socialist environment. The English State sends our letters, telephones, telegrams, educates and, in some cases, feeds the nation's children, pensions off our old citizens and insures our workers against sickness and unemployment. In the eyes, therefore, of thoughtful citizens who rejoice in the beneficent exercise of the State management already experienced there can be no sound $a$ priori reason against the collective ownership and control of the nation's land or the nation's railways. The 


\section{PROBLEMS OF VILLAGE LIFE}

principle has been definitely acknowledged and accepted in cases of the acquisition of land by municipalities, and further in the powers conferred upon County Councils in the Small Holdings Act of 1908 to acquire by purchase such land as they require with a view to its permanent retention by the public authority as the inalienable property of the community. The later phase of land legislation of Ireland, though it employed the mechanism of State purchase, had little in common with the ideal of land nationalization, for the farms and holdings which were secured were not retained by the public authorities, but handed over to individual occupiers through the gradual repayment by easy stages of the purchase money and its interest.

Other arguments ordinarily advanced in defence of the existing condition of land tenure are as follows. The entire structure of rural life would, it is alleged, be subverted by the disappearance of the landlord. The happy relations hitherto prevailing between the Hall, the farm, the Rectory and the cottage would necessarily disappear in a cataclysm which robbed such feudal conditions of all real meaning by converting the land into the property of the community. It is constantly maintained too that the farmer would be far 


\section{SOME OTHER REMEDIES 241}

worse off as a tenant of State land, for in times of exceptional stress and difficulty he can usually reckon on generous treatment at the hands of a sympathetic landlord, whereas the State could not afford to malke reductions and allow abatements in the rent due to the public exchequer. And apart from the farmers, what would happen to the whole kindly system of individual charity which flourishes in our village communities? The spirit of Noblesse oblige attaching to the ownership of the soil is the source of a welcome stream of effort and outlay which goes far to render village life delectable. The soup-kitchen, the readingroom, the clothing club would run a grave risk of collapse if the squire no longer walked over his own land. A clergyman in Oxfordshire recommended a landowner politician to the suffrages of his flock on the ground that the candidate was "a jolly good friend to the parish." This friendship would be seriously undermined if the landlord in question, though his bank balance remained intact, became nevertheless a trespasser on the fields he formerly owned.

Other arguments against schemes of public land-ownership are felt not less keenly than those mentioned above though they are seldom alluded to coram populo. The sever- 
ance of our landed gentry from the private ownership of their estates would at one blow deprive them of all the social and political influence which now attaches to the possession of land in this country. The initial control exercised in some cases over the political attitude of tenants and labourers, the claims put forward on the ground of a special " stake in the country," the social futility of people "belonging to the county" when the county no longer belongs to them-such considerations, however trivial they may appear in the eyes of a detached student of economics or urban politician, will stimulate the landowners of England in their last and unavailing resistance to democratic progress. Nor must one overlook the enormous extent and influence of sport in rural life in England. Against any sudden assault on the private ownership of land a solid wall of prejudice would be erected by appeals to the sport-loving instincts of our countrymen. The importance of hunting and shooting in the eyes of some country residents is amazing : in some cases they absorb the main energies of a man's lifetime and provide almost the entire material for the record of his career. The desire to secure good sport frequently acts as the strongest safeguard against the sale of agricul- 


\section{SOME OTHER REMEDIES}

tural estates, which for various reasons may have ceased to be financially or socially attractive to the owners. Nor are such apprehensions on behalf of country sport confined to the landowners. A very considerable number of our English farmers are genuine lovers of sport, who occasionally ride to hounds and frequently "walk up" their rabbits, or sometimes enjoy by permission or invitation a shoot over the turnips and stubble or a day round through the coverts. Vast sums of money are spent on country sport. The words "Up goes a guinea, off goes a penny, down comes half-a-crown" are not a wholly inaccurate summary of the finance of firstclass pheasant or grouse shooting. Something like a million sterling must be spent on the upkeep of the $\mathbf{1 7 6}$ packs of foxhounds in England alone, apart from the vast sums expended on wages and fodder. In the face of even so moderate, a demand as the valuation of English land impassioned appeals were made to the farmers to resist insidious attempts to destroy English sport and the circulation of money caused by such sport in rural districts. What would happen when a Government boldly declared for State purchase on a large scale of our rural estates? 


\section{PROBLEMS OF VILLAGE LIFE}

Let nobody, therefore, underrate the difficulties which confront the efforts of those who seek to secure the nation's land for the nation's use. We have seen the power of resistance which can be offered by the vested interests of the Drink Trade; these are as nothing to the fight which will be put up by the landowners of the country when the inevitable conflict comes to pass.

One thing is certain. In any great scheme of land acquisition by the State a large expenditure would be required not merely for actual purchase but for improvement. There would have to be a 'general "cleaning up" of our farm land, and just as the Scottish landowners of the eighteenth century followed the best contemporary methods of Dutch agriculturists England might be well advised to enlist the help of Continental experts in the task of making British agriculture what it ought to be. The Danish farmer who, with an inferior soil and climate, is to-day producing more bushels of wheat per acre than ourselves, stands amazed at the careless and slipshod methods employed in many agricultural districts. ${ }^{1}$

1 In Denmark there are Government officials called Konsulents," who not only bring to the farmer's knowle Ige the best and latest scientific methods, but assist him to utilize these in practice 
The useless hedges, the ditches choked with rubbish and weeds, the rudimentary draining, the shocking waste of good manure and the prevailing filth of many farm yards, the inadequate and dilapidated buildings, the encouragement of vermin and the breeding of foxes-all such defects show only too plainly how amazingly slow under existing conditions has been the progress of British agriculture.

There are, of course, exceptions in the case of such general criticisms. Scientific farming makes headway here and there, though sorely hampered by the insecurity of tenure-for the yearly tenancy is typical of English farming and almost peculiar to it in Europe-and the lack of capital and credit.

The most astonishing results have been achieved by the use of chemical manures. Professor Long has received testimony from Wiltshire, Hampshire and the Midland counties as to the vast increase in value due to the judicious application of these manures. One farmer writes " On land, about 100 acres, growing coarse herbage, which neither horses, cattle nor sheep would eat, I have now a beautiful plant of clover. Formerly worth $2 / 6$ an acre, it is now worth $20 /-$." In the case of a high chalk hill in Hampshire we learn that "On one piece of ninety acres, almost 
worthless, the effect is wonderful, and can be seen for miles; the results in feeding stock are most marked, not only in the increase of growth, but in the quality of the grass."

The fiscal difficulties in the way of extensive land purchase by the State would disappear if British Cabinets seriously applied themselves to the task. But for this purpose a radical change must take place in our political outlook. We must realize that in no direction could the nation find a better use for its spare wealth than in buying the land of our own country. In seven years, 1906-1913, over a hundred millions of national debt has been paid off. Had we employed all or even a portion of this immense sum to secure vast tracts of national land at a fair and reasonable price, fixed by the Government's valuation, we should have benefited posterity to a far greater extent than by a mere reduction of the interest to be paid by future generations. The development of our soil on a basis of solid business, freed altogether from the fatal interference of " sport " or else deriving a handsome return from its privileged continuance within carefully maintained limits-such a policy would help to banish unemployment, render our population less dependent on sea-borne food, 


\section{SOME OTHER REMEDIES}

and give an impetus to the home markets almost inconceivable under the existing conditions of agricultural lethargy. In the United Kingdom between sixteen and seventeen million acres of land lie idle. An area larger than the cultivated acreage of Denmark, Belgium and Holland is wholly unused, most of which is capable of useful cultivation. If the taxpayer accepts the principle of investments in the Suez Canal, in Sudan cotton, in Uganda Railways, or the vast expenditure of the South African war, he need have no theoretical misgivings about the wise and productive outlay of the nation's money on the sound security of the nation's land. Rural Reform will have advanced far beyond the timid essays of the past when the wholesale purchase of agricultural land appears as a permanent feature in our annual Budgets.

* * * * * * * *

I am writing these concluding paragraphs on a hillside in Buckinghamshire, surrounded by those delights of an English landscape which charm the eye, but sadden the heart of all who really know the inner life of our villages. The very scenes which find special favour in the sight of the sportsman or the tourist bring thoughts of pity and regret to 


\section{PROBLEMS OF VILLAGE LIFE}

those who look for truth and reality beneath the pleasant surface of the view. The hill on which I write is covered by thin, worthless grass, and short scrub-useless, amid utter neglect, for man or beast; below, some forty acres of good pasture land are reserved for golf ; on every side trees grow singly in most haphazard fashion. Further away compact woods form coverts for thousands of pheasants, and in the distance lies the beautiful vale of Aylesbury, controlled by a great landlord. The eye may range for miles with scarcely the sight of a human habitation, and the chief relaxation of the ill-paid labourer is, apparently, to witness the pursuit of a tame stag by persons who spend far more on one day's run than his entire weekly wages.

How long will England tolerate such misuse of her fertile soil ? The life of the few in such an environment as that which lies around me is full of pleasant things : the truer life of the country-that of those who till the soil and feed the nation-is moribund. Who shall deliver us from the body of this death ? The splendid ideals of Liberalism are too often neutralized by the personal wealth or selfish ambition of its representatives, the cautious concessions of Toryism have no more effect on the maladies of our land system than a gift of 


\section{SOME OTHER REMEDIES 249}

flowers in a cholera camp; the Labour Party has no foothold in the average village.

When in the fulness of time some great statesman comes forward armed with full power and authority to demand a surrender of their stewardship from those who have misused their trust, great will be his opportunity and great his reward. Few can suppose that a system so deeply embedded in our history and traditions can be hastily uprooted, but on the other hand few impartial students of our rural conditions can avoid the conclusion that the day for palliatives is drawing to a close, and that private control of land is our Carthage to be destroyed. Public ownership is, indeed, the only policy which will finally and completely cleanse that Augean stable, our present Land System, of the feudal arrogance, privilege, intimidation, and selfish greed which have shaped the cruel history of rural England. So, for the time being, let every opportunity be taken to extend the principle of collective ownership, timidly put forward in the Small Holdings Act, until the broad and fertile acres of our country are wholly used in the best interests of the nation which owns them. 



\section{BIBLIOGRAPHY}

The student of questions connected with rural life in England may find useful material in the following :ARCH, JosePH.-The Story of his Life: told by himself. 1898.

Aronson, H.—Our Village Homes. 1913.

AshBY and Krva.-Slatistics of some Midland Villages.

Buxton, C. Roden.-Minimum Wages for Agricultural

Labourers. (Cont. Rev., August, 1912.)

Colnivgs, RT. Hon. Jesse.-Land Reform. 1908.

Cox, Harold. - Nationalization and Land Taxation.

Curtuer, W. H. R.-A Short History of English Agriculture. 1909.

Davies, M. F.-Life in an English Village. 1909.

Fondrass, M.-Mother Earth: A Proposal for the Permanent Reconstruction of our Country Life. 1908.

GoNNER, E. C. K.-Common Land and Enclosures. 1912. GreEn, F. E.-The Tyranny of the Country Side. 1913. HAGGaRd, H. Rider.-Rural England. 1906.

Hammond, J. L. lo B.-The Village Labourer (1760-1832). 1911.

Hasbacr, W.-A History of the English Agricultural Labourer (translated by Miss Kenyon). 1908.

Hzath, F. G.-The English Peasantry. 1874. British Rural Life and Labour. 1911. 
HYder, J.-The Case for Land Nationalization. 1913.

JEBB, L. (Mrs. RolaNd WILKINs).-The Small Holdings of England. 1907. The Small Holdings Controversy: Tenancy v. Ownership. 1909. Co-operation in the T'enure of Small Holdings. 1910.

JoHnsor, A. H.-The Disappearance of the Small Landowner. 1909.

KеввеLL, T. E.-The Agricultural Labourer. 1907.

Land Enquiry Committee's Report. Vol. I. 1913. (Issued too late for use in this book.)

DE LAVELEYe.-History of Landed Property in England (translated by Mary ThorP). 1898. A chapter from De la Propriété et ses Formes Primitives.

Levy, Hermann.-Large and Small Holdings : a Study of English Agricultural Economics. (Translated by Miss Kenyon, with additions.) 1911.

Lova, James.-Making the Most of the Land. 1913. Small Holdings. 1913.

Lumsden, James.-Our National Food Supply. 1912.

Mans, H. H.-Life in an Agricultural Village (Sociological Papers). 1905.

Mfasterman, C. F. G., and others.-To Colonise England: A Plea for a Policy. 1907.

MILLIN, G. F.-Life in our Villages. 1891.

MooRe, H. E.-Our Heritage in the Land. 1906.

Oman, C.-The Great Revolt of 1381. 1906.

Parker, Sir Ginbert.-The Land for the People. 1908.

Parliamentary Papers (including Cd. 6894 and Cd. 7421) (Royal Commission on Labour); $\mathrm{Cd} .346$ and $\mathrm{Cd}$. 2376 (Mr. Wilson Fox's Reports on Agricultural Wages); Cd. 4402 (Housing of the Working Classes)

Pedder, D. C.-Where Men Decay: A Survey of Present Rural Conditions. 1908. 


\section{BIBLIOGRAPHY}

PratT, E. A.-Small Holders. 1909. The Transition in Agriculture. 1909. Agricultural Organization. 1912.

Prothero, R. E.-English Farming, Past and Present. 1912.

RADFORD, G.-Agricultural Co-operation. 1910.

Rogers, J. E. Thorold.-Six Centuries of Work and Wages. 1884.

Rowntree, B. SeeboHM.-Land and Labour: Lessons from Belgium. 1911. How the Labourer Lives. 1913.

SudTer, G.-The English Peasantry and the Enclosure of Common Fields. 1907.

Stuвbs, C. W.-The Land and the Labourer. 1891.

Sutherland, WHLiaM.-Rural Regeneration in England. 1913.

TAYLOR, A. W.-Scientific Agriculture in Denmark (an address delivered at the National Liberal Club). 1911.

Turnor, Christophrr.-Land Problems and National Welfare. 1911.

Unwn, Mrs. Frsher, and others.-The Land Hunger : Life under Monopoly. 1913.

WALLACE, A. RUSSELL_L L Land Nationalization.

Wourf, H. W.-Co-operative Banking. 1907. 



\section{NDEX}

AFTORRSTATION, 238

Agriculture, 9, 34, 3, 45, 54-56, $142,244,245$

Agrlcultural Holdings Act, 53

Agricultural Rating Act, 154

Agrlcultural Labourer, 7, 38, 51, 59-94 passim, 107, 114-116, $134,192,212$

Allotments, 176-178

Allowances, 65-67, 156 (see Wages)

Amusements, Village, $80-84$

Arch, Joseph, 10, 35, 89, 97, 192

Ball, John, 18, 20

Belgium, 55

Black Death, 16, 19

Buxton, Mr. C. R., 11

Canada, 214

"Census of Productlon," 227

Charitles, 42, 48, 110, 131

Chesterton, Mr. G. K., 74

Church and Clergy, 19, 20, 24, $124,127 \cdot 129,131,132-135$, $138-140,241$

"Clearings," 31

Collings, Mr. Jesse, 10, 99

Colonies, 226

Commons, 29

Compensatlon, 52

Conscrvatism, 106-109, 139, 248

Co-operation, 53, 199-202

Corn Laws, 39, 161, 214

Cottages, tied, 69,73

County Councils, 47, 117, 184, 189

Credit Banks, 196, 200-205

de Laveleye, M., 31

Denmark, 55, 56, 61, 189, 244

Dictary of Labourers, 85-87

Dullness of Villages, $77 \cdot 79,81$

Education, 95-105

Election Cries, 116

Emigratlon, 64, 92, 93, 166, 167
Enclosure Acts, 14, 26-30

Exodus, Rural, 59-94

Farmers, 50-58, 180, 202, 214

Feudal System, 14, 18, 19, 40

Food Supply, 61, 64, 142, 143

Fox, Mr. Whilson, 9, 189

France, 21, 38, 55, 189, 217

Free Trade, 39, 56, 206-217 passim

Game, 39, 44, 45, 53, 73

Gcrmany, 17, 21, 38, 62, 63, 203

Haggard, Mr. Rlder, 9, 97

Harvest Festlvals, 123

Hasbach, Herr, 9, 32

Health of Rural Population, 71, 72

Housing, 69-76, 146-156

Increment Uncarned, 234, 237

Inns, Vlllage, 82, 83

Insurance, National, 144-146

Ireland, 148, 153, 154, 204

Italy, 38, 63, 64, 189

Jacquerie, 21

Johnson, Rev. Arthur, 27

Kelmscott, 107

Kett, 15

Labour, Hours of, 81 (note)

Labour Party, 113, 114, 148, 248

Land Agents, 180

Land Courts, 161, 162, 211

Land Values, Rating and taxing of, 91, 225.231

Landowncrs, 39.50, 75, 147, 179 218,241

Libcrallsm, 110-113, 148, 248

Machinery, 88,89

Mann, Mrs. H. H., 177

Marlborough, Duke of, 74

Masterman, Mr. C. F. G., 8, 128

Monasterles, Suppresslon of, 32 
Money, Mr. Chlozza, 02

Morality, Vll lage, 137, 138

Nationalisation, Land, 231-249

Newspapers, 111, 112

Nonconformlsts, 121, 122, 125, 135,136

Norway, 82,188

Oid-Age Pensions, 00, 144, 145, 192

Oman, Professor C., 17

Otmoor, 27, 29

Ownership and Tenancy, 182-187

" Oxford Movement," 124

Parish Counclis, 118, 119

Parochial Settlement, Law of, 25

Peasant Revolts, 17, 22, 23

Pointer, Mr. J., 114

Politics, Vlilage, $47,48,49,84$, $106-119,178,183$

Protection, 34, 206-217

Protector Somerset, 24

Prothero, Mr. Rowland, 189

Rafieissen Banks, 203, 205

Railway Freights, 200

Rates and Taxes, 52, 215

Recruits, Army, 62, 88

Rellgion, Village, $120-140$

Rent, 50, 53, 75, 161

Rogers, Thoroid, 26

Roman Catholicism, 125, 137

Bowntree, B. Seebohm, 64, 72
Rural District Counclls, 56, 118 148

Ruskin, 131

Schoolmasters, 104, 105

Small Hoidings, 30, 44, 92, 163197

Smali Holdings Act, 187

Smail Holdings Commissloncrs, 172

Smith, Adam, 26

Socialism, 114, 238, 239

"Speenhamiand System," 33

Sport, 41, 43-46, 79, 80, 178, 179 , 234,242

Standard of Living, 57, 67, 68, 76, $77,85-87$

Statute of Labourers, 16

Strikes, Agticuitural, 17, 130, 224

Swing Rlots, 34, 35, 220

Tariff Reform, (see Protection)

Temperance Reform, 82, 112, 135

Tenure, Agricuitural, 52

Trades Unionism, 35, 89, 160, $217-224,231$

Turnor, Mr. Christopher, 10

Tyler, Wat, 23

Valuation, Land, 228, 234, 243

Wage, Minimum, 158, 159

Wages, $16,65,66,67,75,85,90$, $131,150,156 \cdot 160,213,216$

Yeomen, 31

Zola, La Terre, 217 


\section{The}

Home

Library

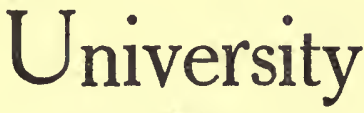

of Modern Knowledge

$A$ Comprehensive Series of New and Specially Written Books

EDITORS :

Prof. GILBERT MURRAY, D.Litt., LL.D., F.B.A.

HERBERT FISHER, LL.D., F.B.A.

Prof. J. ARTHUR THOMSON, M.A.

PROF. WM. T. BREWSTER, M.A.

$1 /-$ net

in cloth

\section{Pages}

$2 / 6$ net

in leather

\section{History and Geography}

3. THE FRENCH REVOLUTION

By HilAiRE Belloc, M.A. (With Maps.) "It is coloured with all the militancy of the author's temperament. "Daily News.

4. HISTORY OF WAR AND PEACE

By G. H. Perris. The Rt. Hon. JAmes Brycr writes: "I have read it with much interest and pleasure, admiring the skill with which you have managed to compress so many facts and views into so small a volume."

8. POLAR EXPLORATION

By Dr W. S. Bruce, F.R.S.E., Leader of the "Scotia" Expedition. (With Maps.) "A very frestly written and interesting narrative." - The Times. 12. THE OPENING-UP OF AFRICA

By Sir H. H. Johnston, (G.C.M.G., F.Z.S. (With Maps.) "The Home University Library is much enriched by this excellent work."-Daily Mail.

\section{I3. MEDI AEVAL, EUROPE}

By H. W. C. Davis, M.A. (With Maps.) "One more illustration of the fact that it takes a complete master of the subject to write briefly upon it."-Manchester Guardian. 
By William BARRY, D.D. "Dr Barry has a wide range of knowledge and an artist's power of selection."-Manchester Guardian.

23. HISTORY OF OUR TIME (1885-1911)

By G. P. Gоосн, M.A. " Mr Gooch contrives to hreathe vitality into his story, and to give us the flesh as well as the bones of recent happenings."-Observer, 25. THE CIVILISATION OF CHINA

By H. A. Giles, LL.D., Professor of Chinese at Cambridge. "In all the mass of facts, Professor Giles never becomes dull. He is always ready with a ghost story or a street adventure for the reader's recreation." - Spectator.

29. THE DAWN OF HISTORY

By J.L. Myres, M.A., F.S.A., Wykeham Professor of Ancient History, Oxford.

"There is not a page in it that is not suggestive." - Manchester Guardian.

33. THE HISTORY OF ENGLAND

$A$ Study in Political Evolution

By Prof. A. F. Pollard, M.A. With a Chronological Table. "It takes its place at once among the authoritative works on English history."-Observer.

34. $C A N A D A$

By A. G. BRADLEY. "The volume makes an immediate appeal to the man who wants to know something vivid and true ahout Canada."-Canadian Gazette. 37. PEOPLES \& PROBLEMS OF INDIA

By Sir T. W. Holderness, K.C.S.I., Permanent Under-Secretary of State of the India Office. "Just the book which newspaper readers require to-day, and a marvel of comprehensiveness."-Pall Mall Gazette.

42. ROME

By W. WARDE Fowler, M.A. "A masterly sketch of Roman character and of what it did for the world."-The Spectator.

48. THE AMERICAN CIVIL WAR

By F. L. PAxson, Professor of American History, Wisconsin University. (With Maps.) "A stirring study."-The Guardian.

51. WARFARE IN BRITAIN

By Hilaire Belloc, M.A. "Rich in suggestion for the historical student." -Edinburgh Evening News.

\section{MASTER MARINERS}

By J.R. Spears. "A continuous story of shipping progress and adventure... It reads like a romance."-Glasgow Herald.

61. NAPOLEON

By HeRBERT F1SHER, LL.D., F.B.A., Vice-Chancellor of Sheffield University. (With Maps.) The story of the great Bonaparte's youth, his career, and his downfall, with some sayings of Napoleon, a genealogy, and a bibliography.

66. THE NAVY AND SEA POWER

By DAvid Hannay. The author traces the growth of naval power from early times, and discusses its principles and effects upon the history of theWestern world.

71. GERMANY OF TO-DAY

By CHARLES TOWER. "It would be difficult to name any better summary."Daily Nezws.

82. PREHISTORIC BRITAIN

By Robert MUNRo, M.A., M.D., LL.D., F.R.S.E. (Illustrated.) 


\section{Literature and Art}

2. SHAKESPEARE

By JoHn MAsEFIELD. "The book is a joy. We have had half-a-dozen more learned books on Shakespeare in the last few years, hut not one so wise." Manchester Guardian.

27. ENGLISH LITERATURE: MODERN

By G. H. MAIR, M.A. "Altogether a fresh and individual book."-Observer. 35. LANDMARKS IN FRENCH LITERATURE

By G. L. Strachey. "It is difficult to imagine how a hetter account of

French Literature could be given in 250 small pages." - The Times.

39. ARCHITECTURE

By Prof. W. R. Lethaвy. (Over forty Illustrations.) "Popular guide-hooks to architecture are, as a rule, not worth much. This volume is a welcome exception."-Building News. "Delightfully bright reading."-Christian World.

43. ENGLISH LITERATURE: MEDIAEVAL

By Prof. W. P. Ker, M.A. "Prof. Ker, one of the soundest scholars in English we have, is the very man to put an outline of English Mediæval Literature hefore the uninstructed public. His knowledge and taste are unimpeachahle, and his style is effective, simple, yet never dry." -The Athenoum,

45. THE ENGLISH LANGUAGE

By L. Prarsall Smith, M.A. "A wholly fascinating study of the different streams that went to the making of the great river of the English speech." Daily Nezes.

\section{GREAT WRITERS OF AMERICA}

By Prof. J. Erskine and Prof. W. P. Trent. "An admirahle summary, from

Franklin to Mark Twain, enlivened by a dry humour."-Atheneum.

63. PAINTERS AND PAINTING

By Sir Frederick WeDMore. (With 16 half-tone illustrations.) From the

Primitives to the Impressionists.

64. DR JOHNSON AND HIS CIRCLE

By John Balley, M.A. "A most delightful essay."-Christian World. 65. THE LITERATURE OF GERMANY

By Professor J. G. Robertson, M.A., Ph.D. "Under the author's skilful treatment the suhject shows life and continuity. - A thenaum.

70. THE VICTORIAN AGE IN LITERATURE

By G. K. Chesterton. "The hook is everywhere immensely alive, and no one will put it down without a sense of having taken a tonic or received a series of electric shocks." - The Times.

73. THE WRITING OF ENGLISH.

By W. T. Brewster, A.M., Professor of English in Columbia University.

"Sensihle in its teaching, and not over-rigidly conventional in its manner." -

Manchester Guardian.

75. ANCIENT ART AND RITUAL.

By JANz E. HARRISON, LL.D., D.Litt. "Charming in style and learned in manner."-Daily News. 
By Gilbert Murray, D.Litt., LL.D., F.B.A., Regius Professor of Greek at Oxford. "A beautiful piece of work. . . Just in the fulness of time, and exactly in the right place. ... Euripides has come into his own."-The Nation.

\section{Science}

7. MODERN GEOGRAPHY

By Dr Marion Nkwbigin. (Illustrated.) "Geography, again : what a dull, tedious study that was wont to be 1 .. But Miss Marion Newbigin invests its dry bones with the flesh and blood of romantic interest."-Daily T'elegraph.

\section{THE EVOLUTION OF PLANTS}

By Dr D. H. Scotr, M.A., F.R.S., late Hon. Keeper of the Jodrell Laboratory, Kew. (Fully illustrated.) "The information is as trustworthy as first-hand knowledge can make it. . . Dr Scott's candid and familiar style makes the difficult subject both fascinating and easy."-Gardeners' Chronicle.

\section{HEALTH AND DISEASE}

By W. Leslie Mackenzie, M.D., Local Government Board, Edinburgh. "Dr Mackenzie adds to a thorough grasp of the problems an illuminating style, and an arresting manner of treating a subject often dull and sometimes unsavoury."-Economist.

\section{INTRODUCTION TO MATHEMATICS}

By A. N. Whitehead, Sc.D., F.R.S. (With Diagrams.) "Mr Whitehead has discharged with conspicuous success the task he is so exceptionally qualified to undertake. For he is one of our great authorities upon the foundations of the science."-Westminster Gazette.

19. THE ANIMAL WORLD

By Professor F. W. Gamble, D.Sc., F.R.S. With Introduction by Sir Oliver Lodge. (Many Illustrations.) "A delight ful and instructive epitome of animal (and vegetable) life. ... A fascinating and suggestive survey."-Morning Post. 20. EVOLUTION

By Professor J. Arthur Thomson and Professor Patrick Geddes. "A many-coloured and romantic panorama, opening up, like no other book we know, a rational vision of world-development."-Belfast News-Letter.

\section{CRIME AND INSANITY}

By Dr C. A. Mercier. "Furnishes much valuable information from one occupying the highest position among medico-legal psychologists."-Asylum News.

\section{PSYCHICAL RESEARCH}

By Sir W. F. Barretr, F.R.S., Professor of Physics, Royal College of Science, Dublin, 1873-rgro. "What he has to say on thought-reading, hypnotism, telepathy, crystal-vision, spiritualism, divinings, and so on, will be read with avidity."-Dundee Courier.

\section{I. ASTRONOMY}

By A. R. Hivks, M.A., Chiet Assistant, Cambridge Observatory. "Original in thought, eclectic in substance, and critical in treatment. . . No better little book is available."-School World. 
By J. Arthur Thomson, M.A., Regius Professor of Natural History, Aberdeen University. "Professor Thomson's delightful literary style is well known; and bere he discourses freshly and easily on the methods of science and its relations with philosophy, art, religion, and practical life."-Aberdeen Journal.

36. CLIMATE AND WEATHER

By Prof. H. N. Dickson, D.Sc.Oxon., M.A., F.R.S.E., President of the Royal Meteorological Society. (With Diagrams.) "Tbe author has succeeded in presenting in a very lucid and agreeahle manner the causes of tbe movements of the atmospbere and of the more stable winds."-Manchester Guardian.

4I. ANTHROPOLOGY

By R. R. MARETT, M.A., Reader in Social Antbropology in Oxford University.

"An ahsolutely perfect handbook, so clear that a child could understand it, so

fascinating and human that it heats fiction 'to a frazzle." - Morning Leader.

44. THE PRINCIPLES OF PHYSIOLOGY

By Prof. J. G. MCKENDRICK, M.D. "It is a delightful and wonderfully comprehensive handling of a subject which, while of importance to all, does not readily lend itself to untechnical explanation. ... Upon every page of it is stamped the impress of a creative imagination."-Giasgow Herald.

46. $M A T T E R A N D E N E R G Y$

By F. SoDDY, M.A., F.R.S. "Prof. Soddy bas successfully accomplished the very difficult task of making pbysics of absorbing interest on popular lines."-Nature.

49. PSYCHOLOGY, THE STUDY OF BEHAVIOUR

By Prof. W. McDougall, F.R.S., M.B. "A happy example of the nontechnical handling of an unwieldy science, suggesting rather tban dogmatising.

It should whet appetites for deeper study."-Christian World.

53. THE MAKING OF THE EARTH

By Prof. J. W. GREgory, F.R.S. (With $3^{8}$ Maps and Figures.) "A fascinating little volume. . . Among tbe many good things contained in tbe series this takes a high place."-The Athenaum.

57. THE HUMAN BODY

By A. Kкגтн, M.D., LL.D., Conservator of Museum and Hunterian Professor, Royal College of Surgeons.' (Illustrated.) 'It literally makes the 'dry bones' to live. It will certainly take a higb place among tbe classics of popular science."-Manchester Guardian.

58. ELECTRICITY

By GisBert KAPP, D.Eng., Professor of Electrical Engineering in the University of Birmingham. (Illustrated.) "It will he appreciated greatly by learners and by the great number of amateurs who are interested in what is one of the most fascinating of scientific studies."-Glasgow Herald.

\section{THE ORIGIN AND NATURE OF LIFE}

By Dr Benjamin Mooke, Professor of Bio.Chemistry, University College,

Liverpool. "Stimulating, learned, lucid."-Livcrpool Courier.

67. CHEMISTRY

By Raphael Meldola, F.R.S., Professor of Chemistry in Finshury Technical College, London. Presents clearly, without the detail demanded by the expert, the way in wbich chemical science bas developed, and the stage it has reached.

72. PLANT LIFE

By Prof. J. B. FARMER, D.Sc., F.R.S. (Illustrated.) "Professor Farmer has contrived to convey all the most vital facts of plant pbysiology, and also to present a good many of the cbief problems which confront investigators to-day in the realms of morphology and of beredity."-Morning Post. 
A General Account of the Science of the Sea. By Sir Jonn MURRAY, K.C.B., F.R.S. (Illus.) "A life's experience is crowded into this volume. A very use. ful feature is the ten pages of illustrations and coloured maps at the end."Gloucester Journal.

79. NERVES

By Prof. D. Fraser HARris, M.D., D.Sc. (Illustrated.) A description, in non-technical language, of the nervous system, its intricate mechanism and the strange phenomena of energy and fatigue, with some practical reflections.

\section{Pbilosopby and Religion}

15. MOHAMMEDANISM

By Prof. D. S. Margol1outh, M.A., D.Litt. "This generous shilling's worth of wisdom. ... A delicate, humorous, and most responsible tractate

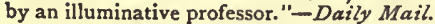

40. THE PROBLEMS OF PHILOSOPHY

By the Hon. Bertrand Russel, F.R.S. "A book that the 'man in the street ' will recognise at once to be a boon. . . . Consistently lucid and non. technical throughout."-Christian World.

47. $B U D D H I S M$

By Mrs Rhys DAv1DS, M.A. "The author presents very attractively as well as very learnedly the philosophy of Buddhism as the greatest scholars of the day interpret it." -Daily News.

5O. NONCONFORMITY: Its ORIGIN and PROGRESS

By Principal W. B. Selb1e, M.A. "The historical part is brilliant in its insight, clarity, and proportion; and in the later chapters Dr Selbie proves himself to be an ideal exponent of sound and moderate views." - Christian World. 54. ETHICS

By G. E. Moore, M.A., Lecturer in Moral Science in Cambridge University;

"A very lucid though closely reasoned outline of the logic of good conduct." -Christian World.

56. THE MAKING OF THE NEW TESTAMENT

By Prof. B. W. BACoN, LL.D., D.D. "Professor Bacon has boldly, and wisely, taken his own line, and has produced, as a result, an extraordinarily vivid, stimulating, and lucid book."-Manchester Guardian.

60. MISSIONS: THEIR RISE and DEVELOPMENT

By Mrs Creighton. "Very interestingly done. . . Its style is simple, direct, unhackneyed, and should find appreciation where a more fervently pious style of writing repels." -Methodist Recorder.

68. COMPARATIVE RELIGION

By Prof. J.Estrin CARPEnTer, D.Litt., Principal of Manchester College,Oxford.

"Puts into the reader's hand a wealth of learning and independent thought." -Christian World.

74. A HISTORY OF FREEDOM OF THOUGHT

By J. B. Burv, Litt.D., LL.D., Regius Professor of Modern History at Cambridge. "A little masterpiece, which every thinking man will enjoy." - The Observer.

\section{LITERATURE OF THE OLD TESTAMENT}

By Prof. GeORge MOORE, D.D., LL.D., of Harvard. A detailed examination of the books of the Old Testament in the light of the most recent research. 


\section{Social Science}

I. PARLIAMENT

Its History, Constitution, and Practice. By Sir Courtenay P. Ilbert, G.C.B., K.C.S.I., Clerk of the House of Commons. "The hest book on the history and practice of the House of Commons since Bagehot's 'Constitution."' - Yorkshire Post.

5. THE STOCK EXCHANGE

By F. W. H1rst, Editor of "The Economist." "To an unfinancial mind must be a revelation. . . . The hook is as clear, vigorous, and sane as Bagehot's 'Lomhard Street,' than which there is no higher compliment."-Morning Leader.

6. IRISH NATIONALITY

By Mrs J. R. Green. "As glowing as it is learned. No book could he more timely."-Daily News.

\section{ro. THE SOCIALIST MOVEMENT}

By J. Ramsay MacDonald, M.P. "Admirahly adapted for the purpose of exposition."-The Times.

1 1. CONSERVATISM

By Lord Hugh Crcil, M.A., M.P. "One of those great little books which seldom appear more than once in a generation."-Morning Post.

16. THE SCIENCE OF WEALTH

By J. A. Hobson, M.A. "Mr J. A. Hobson holds an unique position among

living economists.... Original, reasonable, and illuminating. "-The Nation.

21. LIBERALISM

By L. T. HовноUse, M.A., Professor of Sociology in the University of London. "A hook of rare quality. . . We have nothing but praise for the rapid and masterly summaries of the arguments from first principles which form a large part of this hook."-Westminster Gazette.

\section{THE EVOLUTION OF INDUSTRY}

By D. H. MAcGregor, M.A., Professor of Political Economy in the University of Leeds. "A volume so dispassionate in terms may be read with profit by all interested in the present state of unrest."-Aberdeen Journal.

26. AGRICULTURE

By Prof. W. Somervill.e, F.L.S. "It makes the results of lahoratory work at the University accessihle to the practical farmer."-Athenaum.

30. ELEMENTS OF ENGLISH LAW

By W. M. Geldart, M.A., B.C.L., Vinerian Professor of English Law at Oxford. "Contains a very clear account of the elementary principles underlying the rules of English Law."-Scots Law Times.

38. THE SCHOOL: An Introduction to the Study of Education.

By J. J. Findlav, M.A., Ph.D., Professor of Education in Manchester University. "An amazingly comprehensive volume. ... It is a remarkahle performance, distinguished in its crisp, striking phraseology as well as its inclusiveness of suhject-matter." -Morning Post.

59. ELEMENTS OF POLITICAL ECONOMY

By S. J. Сhapman, M.A., Professor of Political Economy in Manchester University. "Its importance is not to he measured hy its price. Prohahly the hest recent critical exposition of the analytical method in economic science."-Glasgow Herald. 

organisation of the newspaper press, at home and abroad.

77. SHELLEY, GODWIN, AND THEIR CIRCLE

By H. N. BRAILSFORD, M.A. "Mr Brailsford sketches vividly the influence of the French Revolution on Shelley's and Godwin's England; and the charm and strength of his style make his book an authentic contribution to literature." The Bookman.

80. CO-PARTNERSHIP AND PROFIT-SHARING

ByANEUR1N WILI1AMS, M.A.- "A judicious but enthusiastic history, with much interesting speculation on the future of Co-partnership."-Christian World.

8I. PROBLEMS OF VILLAGE LIFE

By E. N. BenNetT, M.A. Discusses the leading aspects of the British land problem, including housing, small holdings, rural credit, and the minimum wage.

83. COMMON-SENSE IN LAW By Prof. P. VINOGRadort, 85. UNEMPLO YMENT By Prof. A. C. Pigov, M.A.

\section{In Preparation}

ANCIENT EGYPT. By F. LL. GRIFFITH, M.A.

THE ANCIENT EAST. By D. G. HOGARTH, M.A., F.B.A.

A SHORT HISTOR Y OF EUROPE. BY HERBERT FISHER, LL.D.

THE BYZANTINE EMPIRE. By Norman H. Baynes.

THE REFORMATION. By President LiNDSAY, LL.D.

A SHORT HISTORY OF RUSSIA. By Prof. MiLyoukov.

MODERN TURKEY. By D. G. HOGaRTH, M.A.

FRANCE OF TO.DAY. By AlBert ThOMAS.

HISTORY OF SCOTLAND. By Prof. R. S. Rait, M.A.

$L A T I N$ AMERICA. By Prof. W. R. SHEPHERD.

HISTORY AND LITERATURE OF SPAIN. By J. Fitzmaurice.

KELLY, F.B.A., Litt.D.

LATIN LITERATURE. By Prof. J. S. PHILlimore.

THE RENAISSANCE. By Miss EDITH SiCHEL.

ITALIAN ART OF THE RENAISSANCE. By ROGER E. FRY.

LITERARY TASTE. By ThOMAS SecCombe.

CHAUCER AND HIS TIME. By Miss G. E. Hadow.

WILLIAM MORRIS AND HIS CIRCLE. By A. CluTtON BROCK.

SCANDINAVIAN HISTORY \& LITERATURE. By T.C. SNOw.

THE MINERAL WORLD. By Sir T. H. Holland, K.C.I.E., D.Sc.

SEX. By Prof. J. A. Thomson and Prof. Patrick Geddes.

THE GROWTH OF EUROPE. By Prof. Grenville Cole.

BETWEEN THE OLD AND NEW TESTAMENTS. By Canon

R. H. Charles, D.D.

A history of Philosophy. By Clement Webe, M.A.

POLITICAL THOUGHT IN ENGLAND: From Bacon to Locke.

By G. P. Gooch, M.A.

POLITICAL THOUGHT IN ENGLAND: From Bentham to J. $S$.

Mill. By Prof. W. L. Davidson.

POLITICAL THOUGHT IN ENGLAND: From Herbert Spencer

to To-day. By ERNEST BARKER, M.A.

THE CRIMINAL AND THE COMMUNITY. By Viscount ST. Cyres. THE CIVIL SERVICE. By Graham Wallas, M.A.

THE SOCIAL SETTLEMENT. By JANE ADDAMS and R. A. WOODS.

GREAT INVENTIONS. By Prof. J. L. MYres, M.A., F.S.A.

TOWN PLANNING. By RAYMOND UNWIN.

\section{London: WILLIAMS AND NORGATE} And of all Bookshops and Bookstalls. 

$7574-5$ 
UC SOUTHERN REGIONAL LIBRARY FACLLITY

A $000692724 \quad 8$ 


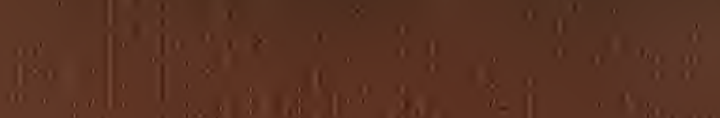

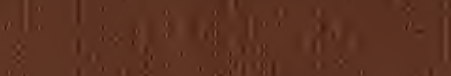

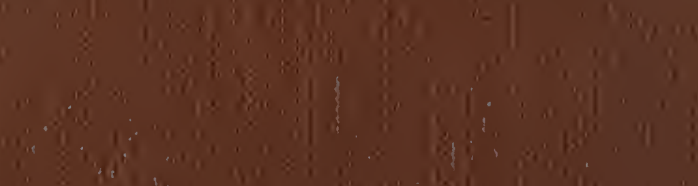
(1)

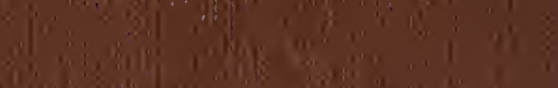

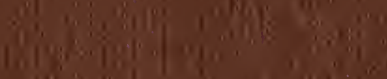

(3)

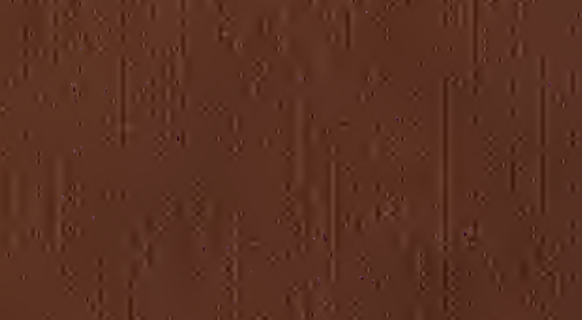

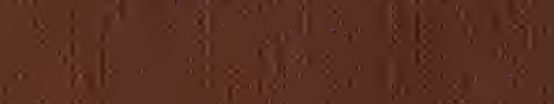

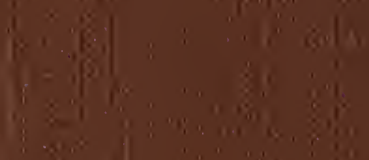

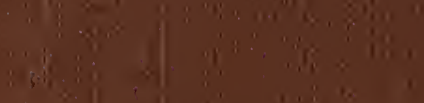

I.

$i^{2}$

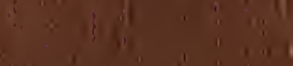

(1) in

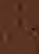

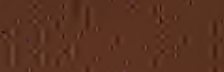

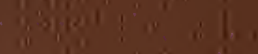

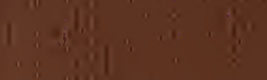

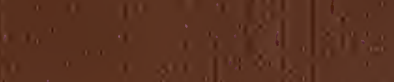

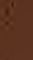

1)

$\left\{\begin{array}{l}1 \\ 3\end{array}\right.$

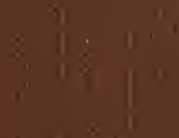

